\title{
Regenerating the Heart of Rural Ontario New Life for Old Mills
}

by

\section{Carly Farmer}

A thesis submitted to the Faculty of Graduate and Postdoctoral Affairs in partial fulfillment of the requirements for the degree of

\section{Master of Architecture}

in

Architecture

\section{Carleton University}

Ottawa, Ontario

$$
\text { (C) } 2017
$$

Carly Farmer 


\section{Abstract}

Old mills are at the heart of most towns in Ontario, and mark the start of the industrial boom which provided good middle class jobs for nearly everyone for over a century. However, from 2002-2012, Ontario lost over 300,000 manufacturing jobs, equivalent to $30 \%$ of the industry. ${ }^{1}$ Typical of many rural industrial communities, Smiths Falls is left with the challenges of a shrinking population and underused or vacant industrial buildings.

This thesis explores innovative ways to adaptively reuse the Wood's Mill Complex in Smiths Falls in a way that positively impacts the region by reconnecting the community with their industrial heritage. The project investigates the role of social equity, cultural vitality, economic prosperity and environmental sustainability in the rehabilitation process and how this contributes to community resilience.

This study of the Wood's Mill Complex could serve as a case

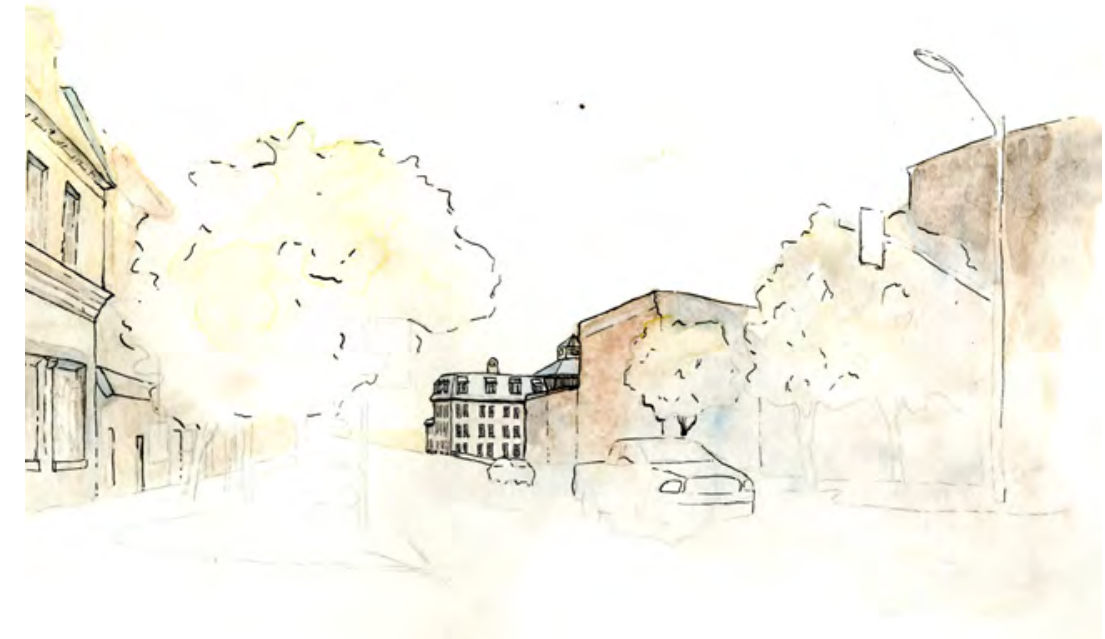
study and guide for the sustainable rehabilitation of other vacant mills and industrial sites in rural Canada.

1 Jeff Rubin, “The Future Looks Bleak for Ontario’s Manufacturing Sector,” The Globe and Mail, December 30, 2013. 


\section{ACKNOWLEDGEMENTS}

I would like to thank my thesis advisors Mariana Esponda Cascajares and Mario Santana Quintero for their valuable guidance on this project.

I would like to thank the Carleton Immersive Media Studio for lending me the survey equipment. A special thanks to Michael Gutland, Sujan Shrestha and Benia Semujanga for their assistance with the total station and laser scanner, and Mario Santana Quintero for the drone videography and photogrammetry. I am most grateful to Steve Vickers and Mario Santana Quintero for their assistance with registering the point cloud.

I would like to extend a big thank you to all the Parks Canada Ontario Waterways staff who granted me access to the Wood's Mill Complex, cleaned up the site, assisted with historical and archival research and otherwise made this project possible: David Martin, Dale MacEchern, Peter Larivière, Colin Hoag, Julianne Cox, Jocelyne Darrah, and Stephane Jolicoeur. Additional thanks to Ted Joynt at the Town of Smiths Falls for providing access to the Waterworks Building and Mill Dam.

Thanks to Barry Padolsky Associates Inc. Architects for access to their archives on the 1990 restoration of the Wood's Mill Complex.

Furthermore, I am grateful for Mario Santana Quintero, Mariana Esponda Cascajares, Susan Ross, Mark Brandt, Jim Mountain and many others for fostering my passion for sustainable conservation. I am grateful for the opportunities to have participated in the National Trust for Canada and Association for Preservation Technology International conferences and NSERC Create Heritage Engineering for the last few years which have inspired this exploration of sustainability. Additionally, I would like to thank Bill Rose and Brian Hierlihy for guidance on assessing and improving building envelope performance.

Lastly, I would like to thank my husband, Luke Farmer, for repairing and maintaining my computer and his unconditional love. 


\section{Table of Contents}

1. Introduction \& Methodology Page 1

1.1 Thesis Questions

1.2 Dublin Principles

1.3 Four Pillars of Sustainability

2. Document \& UnDERSTAND

2.1 Context

2.2.1 Indigenous Heritage

2.2.2 The Heart of the Rideau Canal

2.2.3 Hornet's Snie Industrial Cultural Landscape

5

2.2.4 Wood's Mill Complex

2.2.5 Milling Technology

PAGE 8

2.2 Values Analysis

2.3 Survey

2.4 Condition Assessment

9

11

14

16

18

21

31

35

3. Plan to Protect \& Conserve

3.1 Concept: Regenerating the Heart

PAGE 40

3.2 Design Strategies

41

3.2.1 Circulation \& Access

43

3.2.2 Movement of Water

43

3.2.3 Materials

44

3.2.4 Incrementalism

45

46 
3.2.5 Minimal Intervention

3.2.6 Locals \& Visitors

48

3.2.7 Solar Shading

51

4. INTERVENE \& MAINTAIN

4.1 Conservation Treatments

PAGE 52

4.2 Details

53

4.2.1 Floor Rehabilitation

4.2.2 Granary Façade Replacement

69

4.2.3 Masonry Wall Rehabilitation

71

4.3 Maintenance, Monitoring, Commissioning \& Risk Mitigation

5. Present \& Communicate

PAgE 75

5.1 Interpretation Strategy

76

5.2 Relevance of Thesis

79

6. Conclusion

6.1 Regenerating the Heart

6.2 Bibliography

Page 80

81

83

Appendices

PAge 86 


\section{LIST Of TABLES}

Table 1: Building Resilience in Smiths Falls

Table 2: Nara Grid of the Hornet's Snie Industrial Cultural Landscape

Table 3: Nara Grid for the values of the Wood's Mill Complex

Table 4: Proposed programs for the Wood's Mill Complex

Table 5: How the proposed project can build resilience in Smiths Falls 


\section{List of Appendices}

$\begin{array}{lll}\text { A } & \text { Glossary } & 87 \\ \text { B } & \text { Dublin Principles } & 90 \\ \text { C } & \text { World Heritage List: Rideau Canal } & 91 \\ \text { D } & \text { Canadian Register of Historic Places } & 93 \\ \text { E } & \text { Documentation Workflow } & 94 \\ \text { F } & \text { Building Envelope Analysis } & 97 \\ \text { G } & \text { Community Survey } & 98 \\ \text { H } & \text { Precedent Analysis } & 99\end{array}$




\section{LIST OF ILLUSTRATIONS}

All illustrations are by the author unless otherwise noted.

Figure 0.1 How the proposed project can build resilience in Smiths Falls

1. InTRODUCTION \& MethodOLOGY

Figure 1.2 Methodology diagram

Figure 1.3 Four Pillar Model of Sustainability

Figure 1.4 Applying the Four Pillar model to the Wood's Mill Complex

2. DOCUMENT \& UNDERSTAND

Figure 2.1 Map of treaty boundary by Algonquins of Ontario, 2013.

Figure 2.2 Map of the Rideau Canal, adapted from Kim Whytock \& Associates Inc.

Figure 2.3 Site Plan of Smiths Falls

Figure 2.4 1827-1924 site plans by Commonwealth Historic Resource Management Limited, 1988. pre-1825 and 2016 site plans and colour added by author

Figure 2.5 1852-1988 drawings by Barry Padolsky Architect ltd., 1988. 2016 drawing by author. 17

Figure 2.6 How water powered the mill

Figure 2.7 Timeline of major events: Indigenous (blue); Hornet's Snie (purple); Wood's Mill Complex (red)

Figure 2.8 Heritage designations within the Hornet's Snie Industrial Cultural Landscape

Figure 2.9 Inventory of character-defining features of the Hornet's Snie Industrial Cultural Landscape

Figure 2.10 Park-like setting

Figure 2.11 South facade as seen from Beckwith St. S.

Figure 2.12 Historic commercial centre

Figure 2.13 Panorama of north façade 
Figure 2.14 New locks from 1974

Figure 2.15 Stone arch dam surrounding parking lot

Figure 2.16 Log lifter machine on top of the mill dam

Figure 2.17 Old locks from 1836

Figure 2.18 Canal St. Bridge

Figure 2.19 Mill dam and West Mill foundations

Figure 2.20 Heritage significance of materials, scale adapted from the Association for Preservation Technology,

Figure 2.21 Corbelled masonry and evidence of gable

Figure 2.22 View from granary lookout

Figure 2.23 restored roof and chimney cap

Figure 2.24 Bedrock foundations

Figure 2.25 Steel anchor for embedded floor beams

Figure 2.26 Segmental arch over windows and corbelled bracket

Figure 2.27 West Mill third floor

Figure 2.28 Mitre gear where the drive shaft meets the line shaft

Figure 2.29 wood pulley

Figure 2.30 turbine casing and mitre gear, basement

Figure 2.31 patched floor opening

Figure 2.32 calculations on wall

Figure 2.33 tailrace in West Mill basement

Figure 2.34 Site section looking east, not to scale

Figure 2.35 Site section looking north, not to scale

Figure 2.36 West Mill cross section, not to scale

Figure 2.37 Cross section through point cloud of West Mill

Figure 2.38 Long section through West Mill

Figure 2.39 Area of insulated masonry of East Mill, south façade

Figure 2.40 Insulating the masonry wall during the 1990 rehabilitation. Credit: Barry Padolsky Associates Inc., 1990

Figure 2.41 Bright spots suggest air leakage through the East Mill roof

Figure 2.42 Bright spots suggest air leakage through the walls and around the window of the Granary 
Figure 2.43 Panorama of the Wood's Mill Complex

Figure 2.44 Displaced and cracked concrete retaining wall of the Hornet's Snie

Figure 2.45 Overgrown culvert northwest of the Waterworks Building

\section{Plan to Protect \& Conserve}

Figure 3.1 Diagram of human circulatory system with heart pumping oxygen through the body

Figure 3.2 Diagram of Mill pumping cultural vitality and resilience

Figure 3.3 Circulation through the site

Figure 3.4 Rain Chain showing movement of stormwater through site

Figure 3.5 Water movement through the West Mill

Figure 3.6 Channel glass partition wall, Credit: California Academy of Sciences

Figure 3.7 Frozen rain chain, Credit: Scott Lavender 2011

Figure 3.8 Highly reflective curtain wall with vertical wood louvers. Maple Sunscreening, n.d.

Figure 3.8 Three phases of development proposed for Wood's Mill Complex

Figure 3.9 Phases of development for Hornet's Snie Industrial Cultural Landscape

Figure 3.10 Historic masonry walls (red) and circulation core (purple) to be maintained

Figure 3.11 Sectional representations of program in Wood's Mill Complex

Figure 3.12 Target demographic for existing spaces

Figure 3.13 Target demographic for proposed spaces

Figure 3.14 Architectural louvers are automated to optimize passive solar heating and cooling

\section{INTERVENE \& MAINTAIN}

Figure 4.1 Exploded axonometric of conservation treatments to Wood's Mill Complex 
Figure 4.7 Basement floor plans $\quad 59$

Figure 4.8 Second floor plans $\quad 60$

Figure 4.9 Third floor plan $\quad 61$

Figure 4.10 Fourth floor plans

Figutre 4.11 Headrace and bridge leading to main entrance of Wood's Mill Complex 63

Figure 4.12 Co-working spaces and library surrounding board room 64

Figure 4.13 Board room wrapped around drive shaft, the heart of innovation $\quad 64$

Figure 4.14 Interpretive area of West Mill basement with views to water exitng the tailrace 65

Figure 4.15 Digital fabrication lab with views to Water Works Building 65

Figure 4.16 Site model $1 \mathrm{~m} \times 1 \mathrm{~m}$ at a scale of 1:350 66

Figure 4.17 Detail of proposed headrace and path around the Waterworks Bldg 66

Figure 4.18 Detail of forebay, penstock and Wood's Mill Complex 66

Figure 4.19 View of the Hornet's Snie Industrial Cultural Landscape from Beckwith Street South, looking north 67

Figure 4.20 Detail of culvert, daylighted stream and path behind the Waterworks Building 67

Figure 4.21 Detail of the Lockmaster's house $\quad 67$

Figure 4.22 View of the Hornet's Snie Industrial Cultural Landscape from main branch of the Rideau Canal, 68 looking north

Figure 4.23 West Mill floor detail $\quad 70$

Figure 4.24 View of the Hornet's Snie Industrial Cultural Landscape from main branch of the Rideau Canal, 72 looking north

Figure 4.25 Vapour permeable wall assembly, Credit: Historic England, 2012

\section{Present \& Communicate}

Figure 5.1 Blue star creeper flowers give the illusion of water flowing across the land for a few weeks every year Credit: Baldur-Garten

Figure 5.2 Close-up view of blue star creeper flowers. Credit: Baldur-Garten

Figure 5.3 Blue star creeper following the original path of the river, path and daylighted stream 


\section{Appendix E}

Figure E.1 Laser scanning the basement of the West Mill

Figure E.2 Laser scanning the exterior

Figure E.3 Registering the point clouds in Faro Scene 95

Figure E.4 Total station Credit: Sujan Shrestha

Figure E.5 Flying the drone

Figure E.6 The final point cloud $\quad 95$

Figure E.7 Digital fabrication with the CNC 96

Figure E.8 Detail of the CNC doing the final pass 96

Figure E.9 Applying the stain to the model 96

\section{APPENDIX H}

Figure H.1 Naas Fabriker aerial view, Credit: Naas Fabriker 99

Figure H.2 Fogo Island Inn, Saunders Architecture, 2013

Figure H.3 Tower Studio. Credit: Saunders Architecture, 2011

Figure H.4 Fogo Island Inn, Saunders Architecture, 2013

Figure H.5 Long Studio, Saunders Architecture, 2011

Figure H.6 Long Studio, Saunders Architecture, 2011

Figure H.7 Fort McLeod, Alberta mainstreet, 2015

Figure H.8 Fort McLeod Main Street Office, 2015

Figure H.9 Win this Space logo for Huron East. Credit: Municipality of Huron East 103

Figure H.10 Main Street, Seaforth, Ontario, 1988. Credit: Francois LeBlanc. 103

Figure H.11 Artscape Wychwood Barns farmer's market. Credit: Artscape 105

Figure H.12 Artscape Wychwood Barns greenhouse. Credit: Artscape 105

Figure H.13 Artscape Wychwood Barns farmer's market. Credit: Artscape 105 
1.

INTRODUCTION \& Methodology 


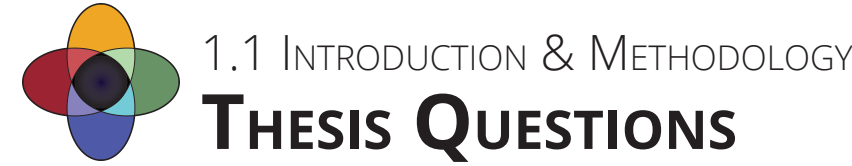

How can a holistic sustainable approach to reusing industrial heritage improve resilience in rural communities overcoming the effects of deindustrialization?

How can repurposing the Wood's Mill Complex and interpretation of the Hornet's Snie Industrial Cultural Landscape bring renewed interest, investment and delight to Smiths Falls?

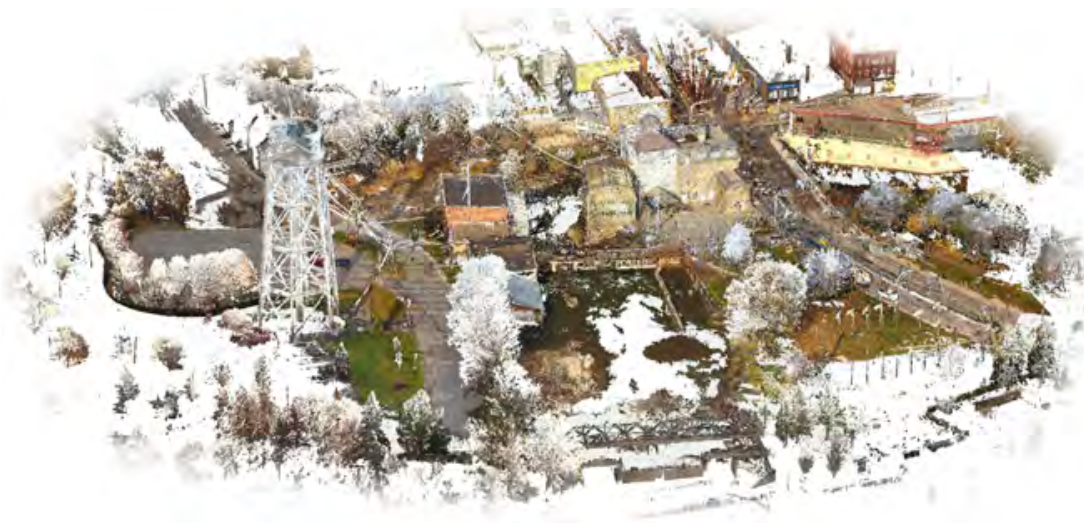

Figure 1.1. Screenshot of point cloud 


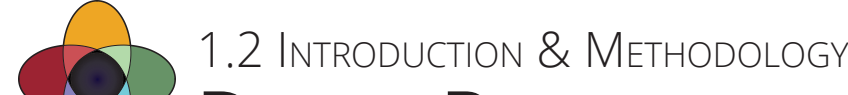 Dublin Principles}

The International Council on Monuments and Sites (ICOMOS) and the International Committee for the Conservation of Industrial Heritage (TICCIH) developed a charter in 2011 for the Conservation of Industrial Heritage Sites, Structures, Areas and Landscapes, called the "Dublin Principles." (See Appendix B) This charter was selected because it is most relevant to the 19th century industrial heritage of Smiths Falls and builds on the best practices established in previous international charters and the Standards and Guidelines for the Conservation of Historic Places in Canada. Furthermore, the Dublin Principles place more emphasis on intangible heritage, socio-economic sustainability, cultural landscapes, documentation, and interpretation which gives a more comprehensive perspective to heritage conservation.

The research takes place on two scales or dimensions as illustrated in figure 1.3. First, the "community scale" will look at the 1 ICOMOS and TICCIH, "Principles for the Conservation of Industrial Heritage Sites, Structures, Areas and Landscapes," November 28, 2011, http://www.international. icomos.org/Paris2011/GA2011_ICOMOS_TICCIH_joint_principles_EN_FR_final_20120110.pdf. socio-economic dimensions including community context, indigenous heritage, interpretation, etc. The "technology scale" complements this by investigating technical aspects of the building and its construction. This includes surveying, condition assessment and upgrades for the building envelope. This holistic approach will guide the design of the new architectural program and interpretation of the surrounding industrial cultural landscape.

The structure of the thesis follows the four steps of the Dublin Principles: document and understand; plan to protect and conserve; intervene and maintain; present and communicate.

The scope of the research includes a broad look at the entire Hornet's Snie industrial cultural landscape with a deeper focus on the Wood's Mill Complex. 


\section{Community Scale}

\section{Dublin \\ Principles}

\section{Tecnology Scale}

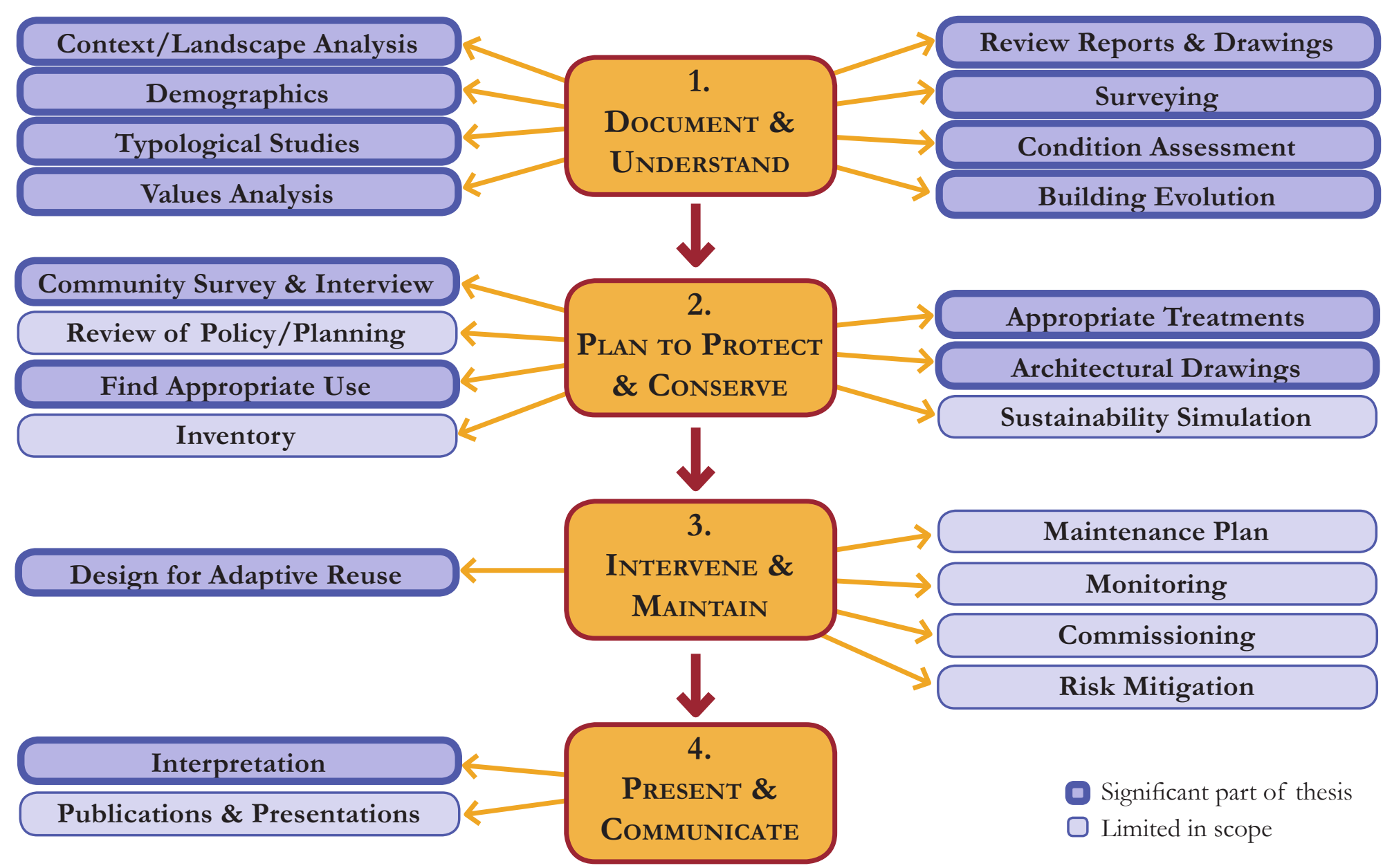




\subsection{Introduction \& Methodology
Four Pillars of Sustainability}

In the face of turbulent change, resilient communities are capable of anticipating risk, limiting impact, and rapidly bouncing back through survival, adaptability, evolution, and growth ${ }^{1}$. The guiding principle of the Building Resilience: Practical Guidelines for the Sustainable Rehabilitation of Buildings in Canada is that "heritage conservation contributes to creating a sustainable built environment and resilient communities.",2

Sustainable development is often said to depend on the three pillars of social equity, environmental responsibility and economic viability; however, this can only be realized once it becomes a wholeheartedly embraced part of our culture. ${ }^{3}$ Accordingly, the increasingly recognized fourth pillar of cultural vitality builds on the notion of community resilience by emphasizing creativity, innovation, diversity and well-being $\cdot{ }^{4}$ Heritage conservation improves community resilience when it embraces and strengthens each of the four pillars.
The four-pillar model of sustainability (see figure 1.4) based on the writings of Jon Hawkes will provide structure to this thesis and ensure that a holistic view of sustainability is maintained throughout. The icon to the left of each heading indicates which of the four pillars that section addresses.

Figure 1.5 illustrates where each of the four pillars have influenced the program or fabric of the Wood's Mill Complex.

Smiths Falls is currently facing a number of social, economic, environmental and cultural challenges. Table 1 illustrates how thoughtful rehabilitation of the Wood's Mills Complex and surrounding industrial cultural landscape could help.

1 M. John Plodinec, "Definitions of Resilience: An Analysis," Community and Regional Resilience Institute (CARRI), 2009.

2 Federal Provincial Territorial Ministers of Culture and Heritage in Canada, Building Resilience: Practical Guidelines for the Sustainable Rehabilitation of Buildings in Canada (Ottawa: Library and Archives Canada, 2016).

3 Jon Hawkes, The Fourth Pillar of Sustainability: Culture's Essential Role in Public Planning (Common Ground, 2001).

4 Ibid. 


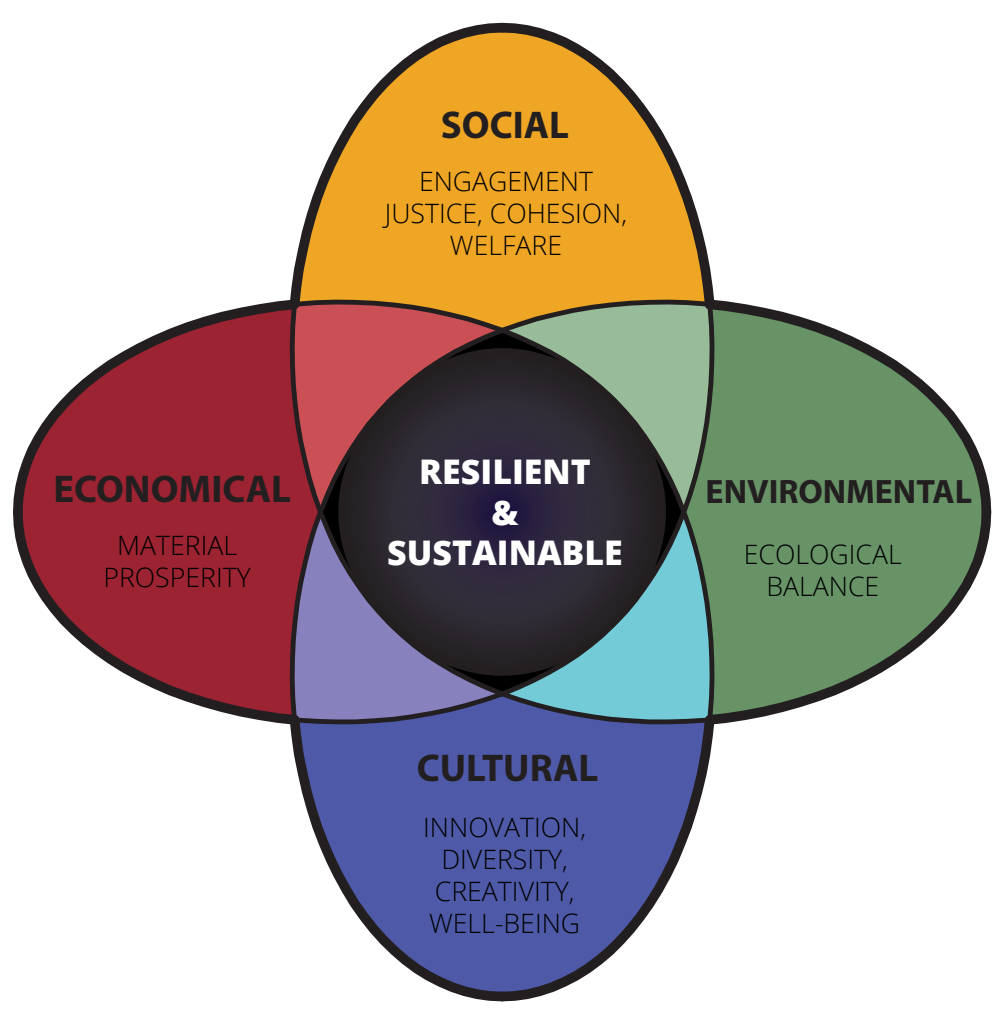

Figure 1.3. Four Pillar Model of Sustainability

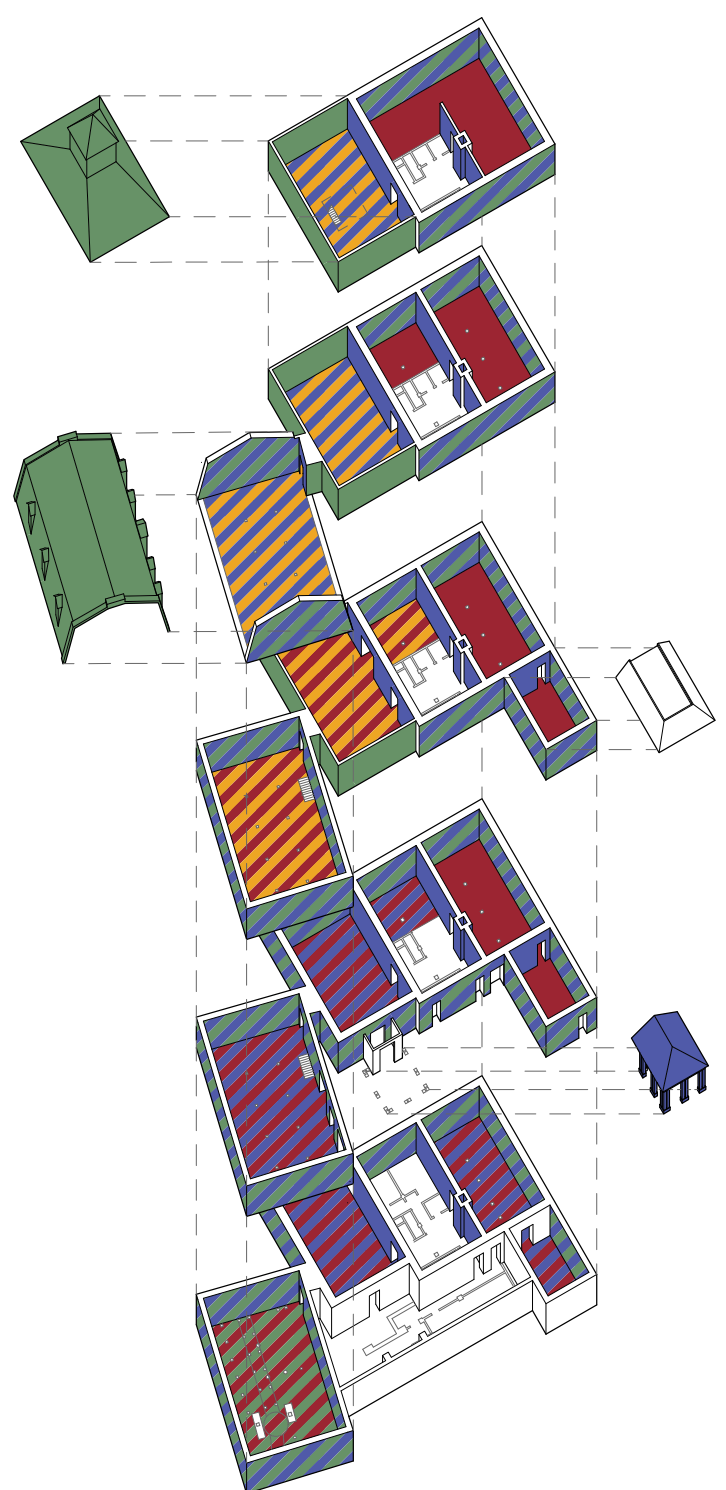

Four Pillars of Sustainability

\section{Economic
Social}

Environmenta

Cultural 


\begin{tabular}{|c|c|c|}
\hline \multicolumn{3}{|c|}{ How to Build Resilience in Smiths Falls? } \\
\hline & Current Problems & Proposed Solutions \\
\hline \multirow{5}{*}{ 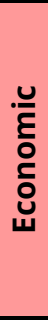 } & $\begin{array}{l}\text { sudden loss of most manufacturing jobs; lack of quality } \\
\text { year-round jobs }\end{array}$ & diversify the economy through heritage tourism \\
\hline & lack of diversity in the local economy & encourage innovation and entrepreneurship; provide business training \\
\hline & $\begin{array}{l}\text { high unemployment rate, high dependency on social } \\
\text { assistance (welfare) }\end{array}$ & $\begin{array}{l}\text { provide opportunities to learn new skills and start new businesses; create new business } \\
\text { and social enterprises which are financially self-sustaining }\end{array}$ \\
\hline & lower tax base due to shrinking population & make town more desirable place to live (see social and cultural) \\
\hline & vacant storefronts in central business district & Encourage business start-ups to locate in downtown core \\
\hline \multirow{3}{*}{ 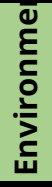 } & vacant buildings & repurpose buildings for contemporary use \\
\hline & carbon emissions and climate change & sustainably retrofit building envelope; generate clean renewable electricity \\
\hline & landfill waste and pollution & encourage a culture of reuse and repair \\
\hline \multirow{4}{*}{$\overline{\frac{\pi}{\pi}}$} & $\begin{array}{l}\text { homeless youth, and youth doing drugs and alcohol, high } \\
\text { teen pregnancy rate }\end{array}$ & $\begin{array}{l}\text { give youth 'something to do;' provide job opportunities for youth; build healthy } \\
\text { relationships across generations }\end{array}$ \\
\hline & youth moving away to large urban centres & Engage youth and help them to remake the community; collaborate with local schools. \\
\hline & intolerance for minority groups & $\begin{array}{l}\text { celebrate diversity; foster relationships between indigenous and non-indigenous people; } \\
\text { interpret heritage values from multiple perspectives }\end{array}$ \\
\hline & $\begin{array}{l}\text { shrinking population, especially among the working } \\
\text { population }\end{array}$ & make town more desirable place to live and visit \\
\hline \multirow{4}{*}{ 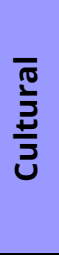 } & vacant industrial/heritage buildings & repurpose buildings for contemporary use \\
\hline & difficult to understand industrial heritage of Smiths Falls & interpret local industrial heritage and the evolving industrial cultural landscape \\
\hline & $\begin{array}{l}\text { tourism industry shuts down outside of summer boating } \\
\text { season }\end{array}$ & $\begin{array}{l}\text { enhance museum so it is more desirable for repeat visits; diversify tourist experience to } \\
\text { include the arts }\end{array}$ \\
\hline & lack of educational opportunities for artists & promote interaction and reciprocal learning between residents and visitors \\
\hline
\end{tabular}


2.

DOCUMENT \& UNDERSTAND 
Context: Indigenous Heritage

Archaelogical evidence indicates that indigenous people inhabited eastern Ontario since the glaciers retreated. Iroquois (Haudenosaunee) traditional territory extended from the northern shores of Lake Ontario and the St. Lawrence through New York State and included the southern portion of the Rideau Canal. The Algonquin (Anishinaabe) traditional territory consisted of the Ottawa river watershed, including Smiths Falls and the northern portion of the Rideau Canal. ${ }^{1}$ Given that Smiths Falls was formerly the site of a significant waterfall, it was likely a place of importance for gatherings and fishing. ${ }^{2}$

While there are no known promises made to the Algonquin people with regards to land acquisition for constructing the Rideau Canal, it is likely that the Algonquin people assisted in the project. However, upon completion of the Canal and with the establishment of the colonial government, indigenous people were effectively pushed out of the Rideau Corridor. ${ }^{3}$

The Algonquins of Ontario land claim Agreement-in-Principle was signed October 18, 2016 which marks a major milestone in identifying and protecting Algonquin land and rights within the settlement area boundary (Figure 2.1). As long as Parks Canada maintains ownership of the Wood's Mill Complex, this would minimally impact its development. However, upon disposal of the property or its interests (such as a lease agreement), there is a duty to consult with the Algonquin. ${ }^{4}$ The three Algonquin groups in proximity to Smiths Falls which potentially have interest in the Wood's Mill Complex include: Sharbot Obaadjiwan (Sharbot Lake); Ardoch (Snimikobi); and the Ottawa community. ${ }^{5}$

1 Herb Stovel et al., "The Cultural Landscapes of the Rideau Canal Corridor: Phase II Study" (Institute for Heritage Education study team, 1998).

2 Peter Larivière (Manager of Indigenous Relations at Parks Canada), personal communication, December 19, 2016.

3 Ibid.

4 Algonquins of Ontario, "Our Proud History," 2013, http://www.tanakiwin.com/algonquins-of-ontario/our-proud-history/.

5 Larivière, 2016. 


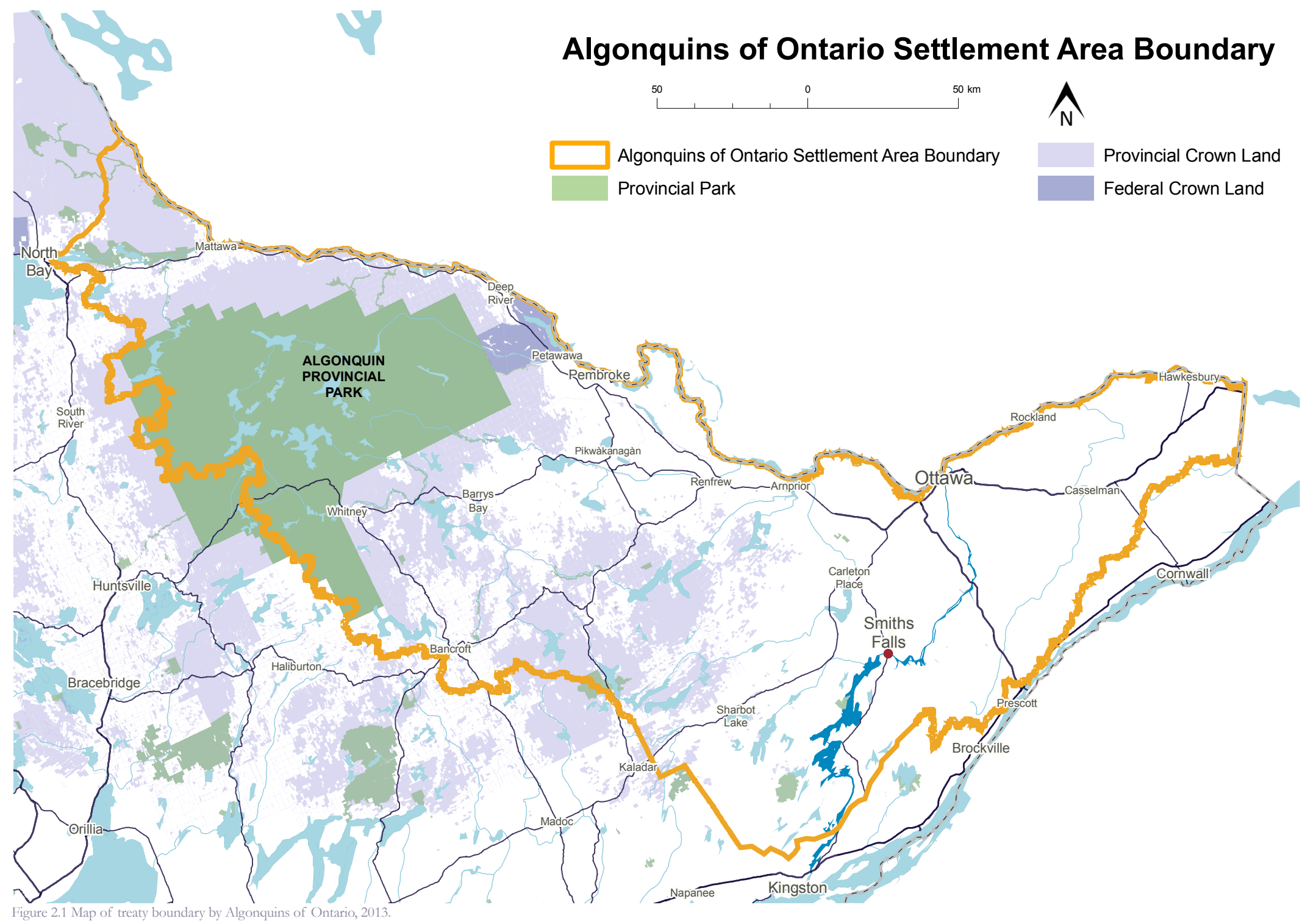




\section{Context: the Heart of the Rideau Canal}

Smiths Falls is situated at the mid-point of the $202 \mathrm{~km}$ Rideau Canal World Heritage Site which connects Kingston and Ottawa. UNESCO recognizes the Rideau Canal for its Outstanding Universal Value as the best-preserved example of a slackwater canal in North America dating from the early 19th century and as a canal used for a military purpose of the fight to control the northern portion of the American continent ${ }^{1}$. See Appendix C.

The natural beauty, recreational values, and historic significance of the Rideau Canal draw over 1 million people visit the locks every summer which generate over $\$ 12$ million in tourism revenue and creates over 600 full time jobs. ${ }^{2}$ Smiths Falls is easily accessible by boat, car, Via Rail, Greyhound bus and snowmobile (figure 2.2). Additionally, two recreational multi-use trails connect Smiths Falls to other towns and cities across Canada. ${ }^{3}$
Thomas Smyth was the first settler to acquire land in the area and build a mill at the falls, followed by Abel Russell Ward often considered the first permanent settler. After construction of the locks, Ward and others harnessed the waste water to power a variety of mills (figure 2.3). Milling equipment, schooner ships, and agricultural implements were also produced in Smiths Falls. ${ }^{4}$

Throughout most of its history, Smiths Falls was a thriving industrial town with a peak population of 9,140 in 2001 . However, between 2007 and 2012, nearly 1,700 jobs (or 40\% of the adult workforce) vanished with the closure of the town's largest employers ${ }^{6}$. By 2011, the population had dropped $6.1 \% \%^{7}$.

UNESCO World Heritage Centre, "Rideau Canal," UNESCO World Heritage Centre, 2016.

2 The Rideau Roundtable "Facts about the Rideau," 2016.

3 The Great Trail, "Lanark County," TC Trail, May 19, 2016.

4 Commonwealth Historic Resource Management Limited, "A History of the Wood's Mills Complex Smiths Falls," April 1988.

5 Statistics Canada, "Census Subdivision of Smiths Falls," February 8, 2012

6 Town of Smiths Falls, "Smiths Falls Strategy to Welcome Newcomers," 2012.

7 Statistics Canada, 2012. 


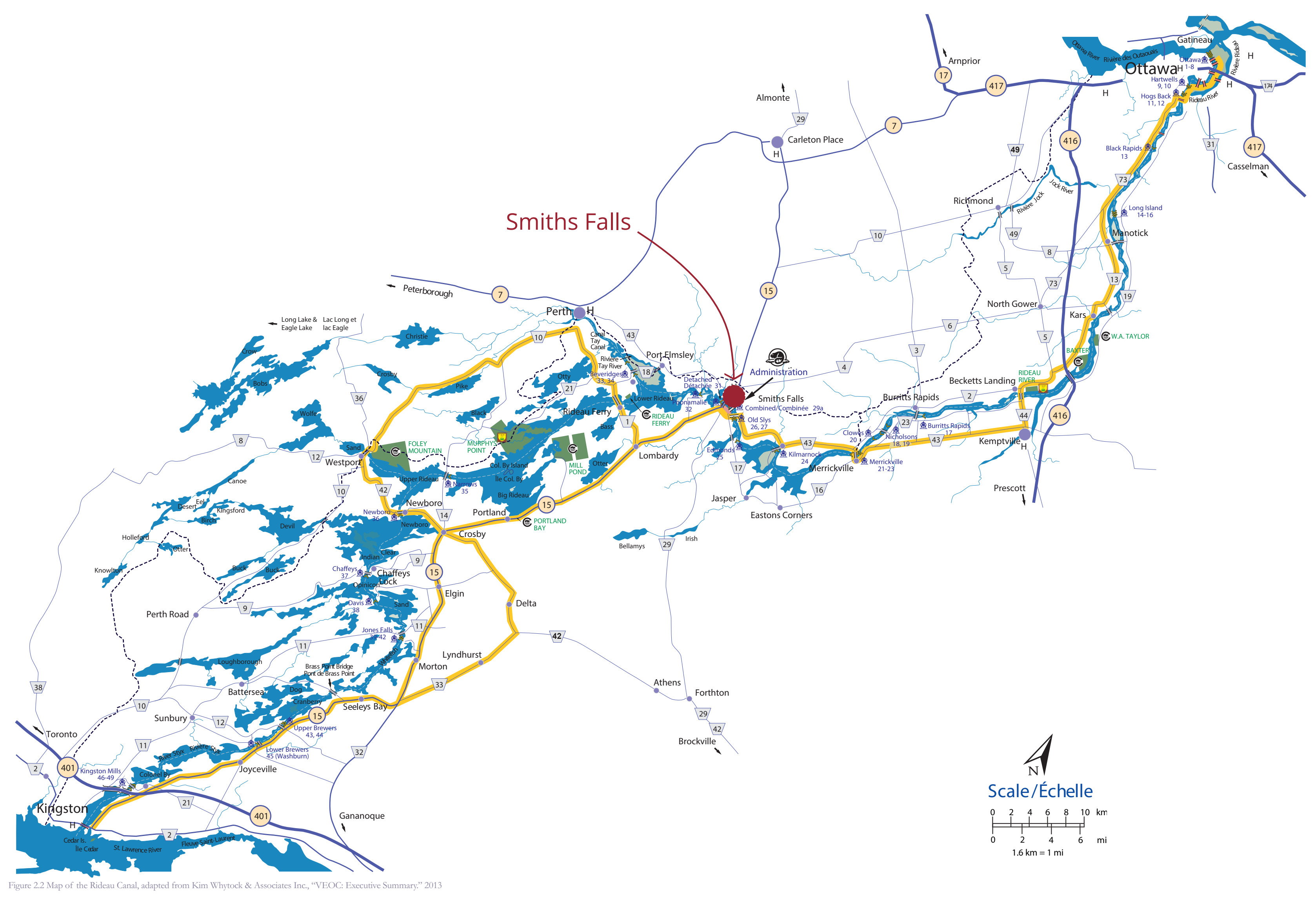




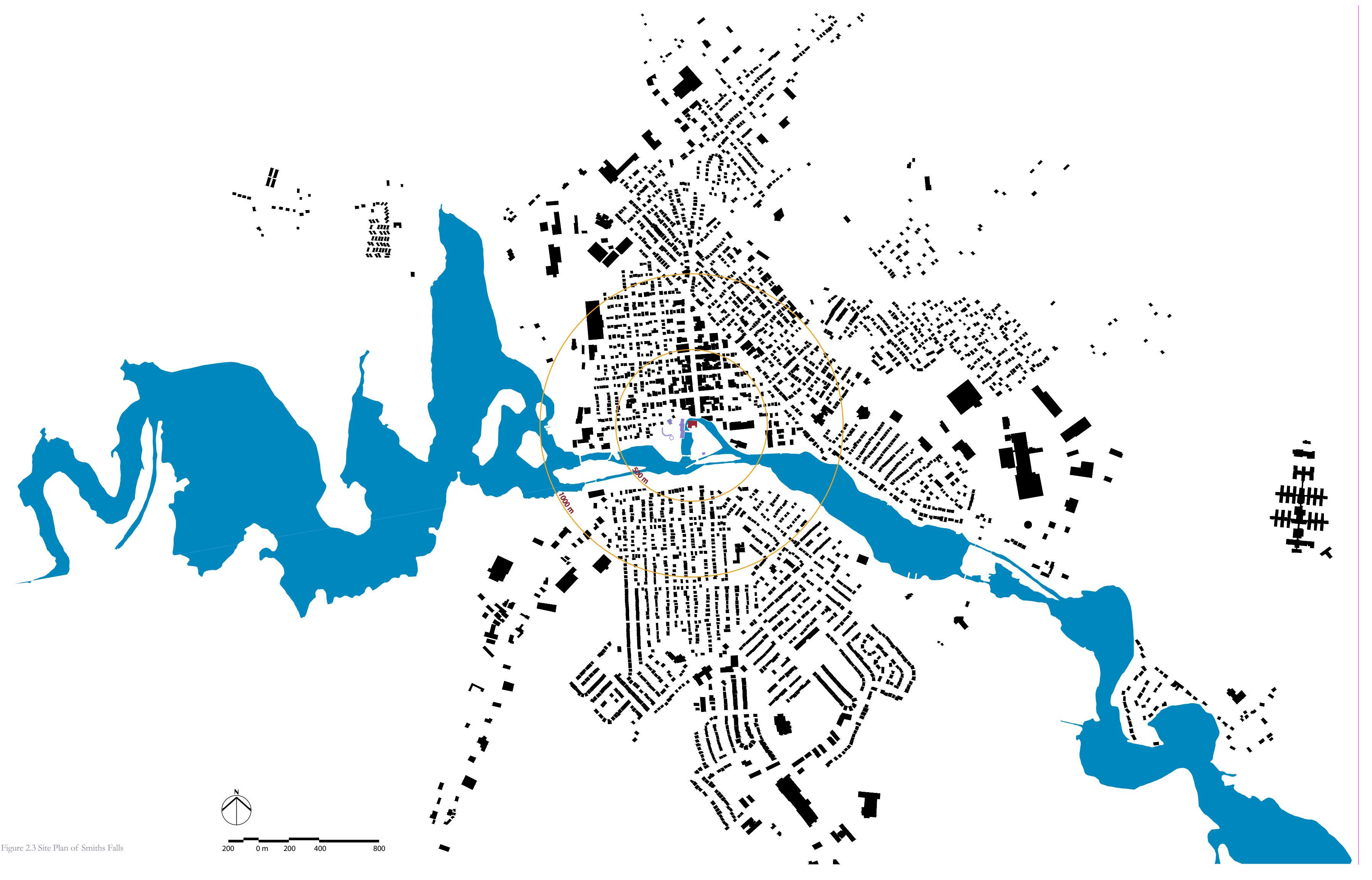




\section{Context: Hornet's Snie Industrial Cultural Landscape}

Prior to the arrival of the European settlers, Smiths Falls was the site of one of Eastern Ontario's more prominent waterfalls where the river fell $11 \mathrm{~m}$ in less than $0.4 \mathrm{~km}$. There were many islands formed by dry flood channels (called snies) with the main watercourse winding around the northwest end of Jason Island. The dam redirected the river through the Hornet's Snie at the south end of Jason Island to power Smyth's mill (figure 2.4, 1827 site plan). ${ }^{1}$

This dam was replaced by a stone arch dam during construction of the Rideau Canal Smiths Falls Combined Lock. Ward Island was also created at this time by cutting a channel for the locks through the 1 Commonwealth Historic Resource Management Limited, 1988.

2 Ibid.

3 Ken W. Watson, A History of the Rideau Lockstations (Friends of the Rideau, 2000). peninsula (figure 2.4, 1832 site plan). Mills were built along the Hornet's Snie to harness the wastewater power. The milling industries peaked in the 1880s and 1890s where the mill dam and many flumes diverted water to the mills. The Canal Street steel truss bridge was built in $1924{ }^{2}$

Land was reclaimed and Jason Island gradually became part of the main land with the stone arch dam acting as a barrier edge to a parking lot. Due to fissures in the rocks and difficulties maintaining water levels, a new lock channel was cut through Ward Island in 1974 (figure 2.4, 2016 site plan). ${ }^{3}$ 


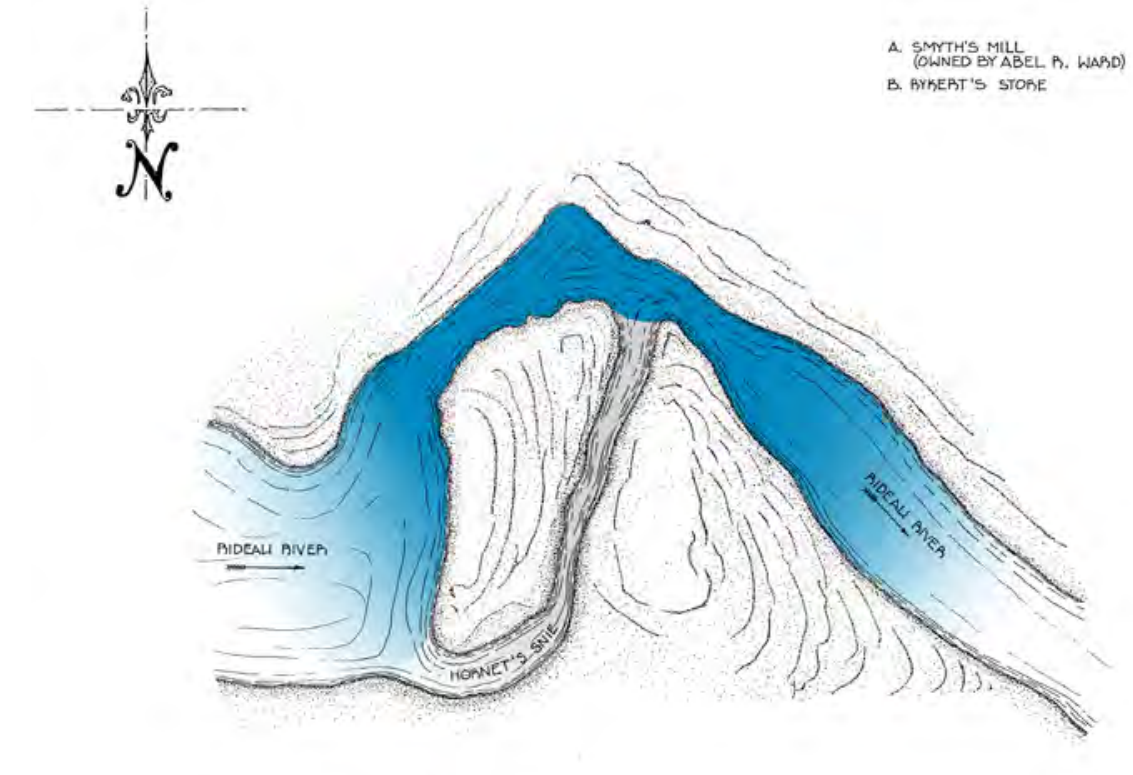

WOOD'S MILL COMPLEX
SITE PLAN, BEFFRE 1825
No

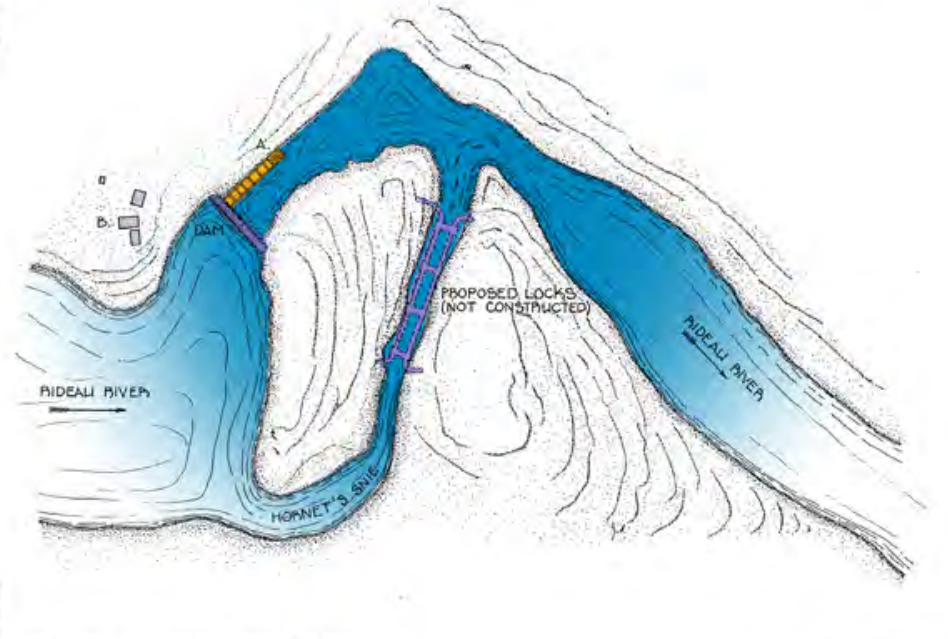

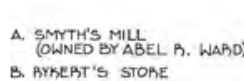

$x^{2}=-1$
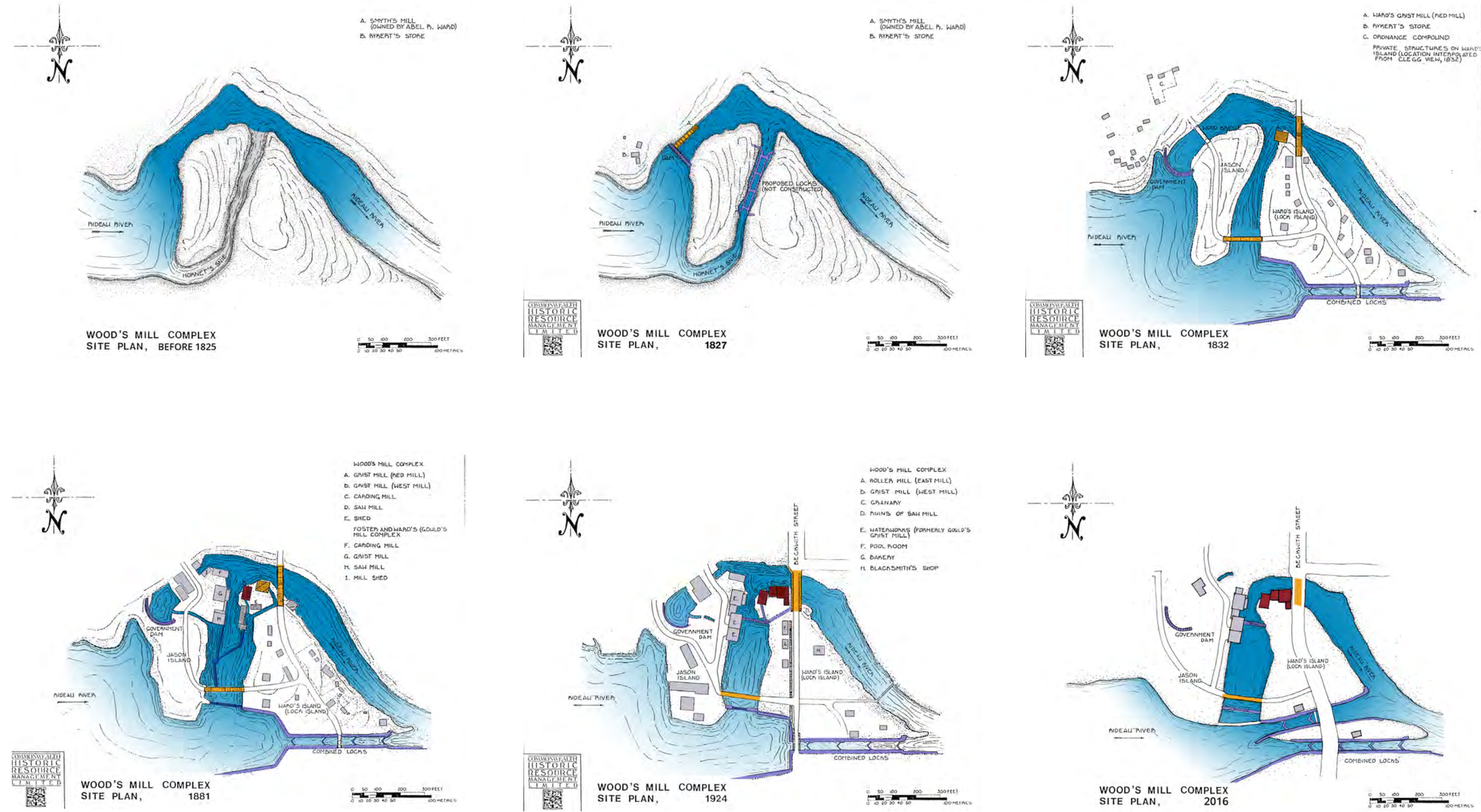
Context: Wood's Mill Complex

Abel Russell Ward built the "Red Mill" in 1832 and the "West Mill" in 1852. In the early years, the flour serviced the canal construction crews and local market with surplus going to Montreal and New York. Alexander Wood purchased the West Mill in 1880 and upgraded it in 1881 and 1887 to merchant flour mills. In 1887, the gable ends were raised and cantilevered to accommodate a mansard roof and make room for the new roller machinery. In 1892, Wood replaced the Red Mill with the East Mill, granary and office wing. The granary stored large supplies of prairie wheat for year-round milling and was constructed of heavy timber and clad with corrugated metal exterior siding. ${ }^{1}$

Smiths Falls Electric Light Company leased the mills in 1893 and installed a dynamo. From 1907 to 1919 the widow Mary Chalmers Wood owned and operated the mill. She erected a new concrete dam, new steel flume, and equipment for the bakery on site. Other businesses

1 Commonwealth Historic Resource Management Limited, 1988.

2 Ibid

3 Ibid. included a repair shop, blacksmith shop, and confectionary shop. The United Farmers of Ontario political party bought and operated the mills from 1919 to $1923 .^{2}$

The Town of Smiths Falls purchased the property in 1923 and removed the granary in 1924. Some milling was done as late as 1930 however, the complex was also used for Brewer's warehouse and beer store, and later, offices and storage for Consumer's Coal Company. In the 1950s, the East Mill was converted into apartments and in 1981, purchased by Parks Canada. In 1990, the Rideau Canal Museum opened inside the reconstructed granary and Parks Canada offices moved to the East Mill. Today the restored Wood's Mill Complex is an integral part of the Smiths Falls downtown streetscape, waterfront parks and industrial cultural landscape. ${ }^{3}$

Figure 2.5 illustrates the evolution of the complex. 

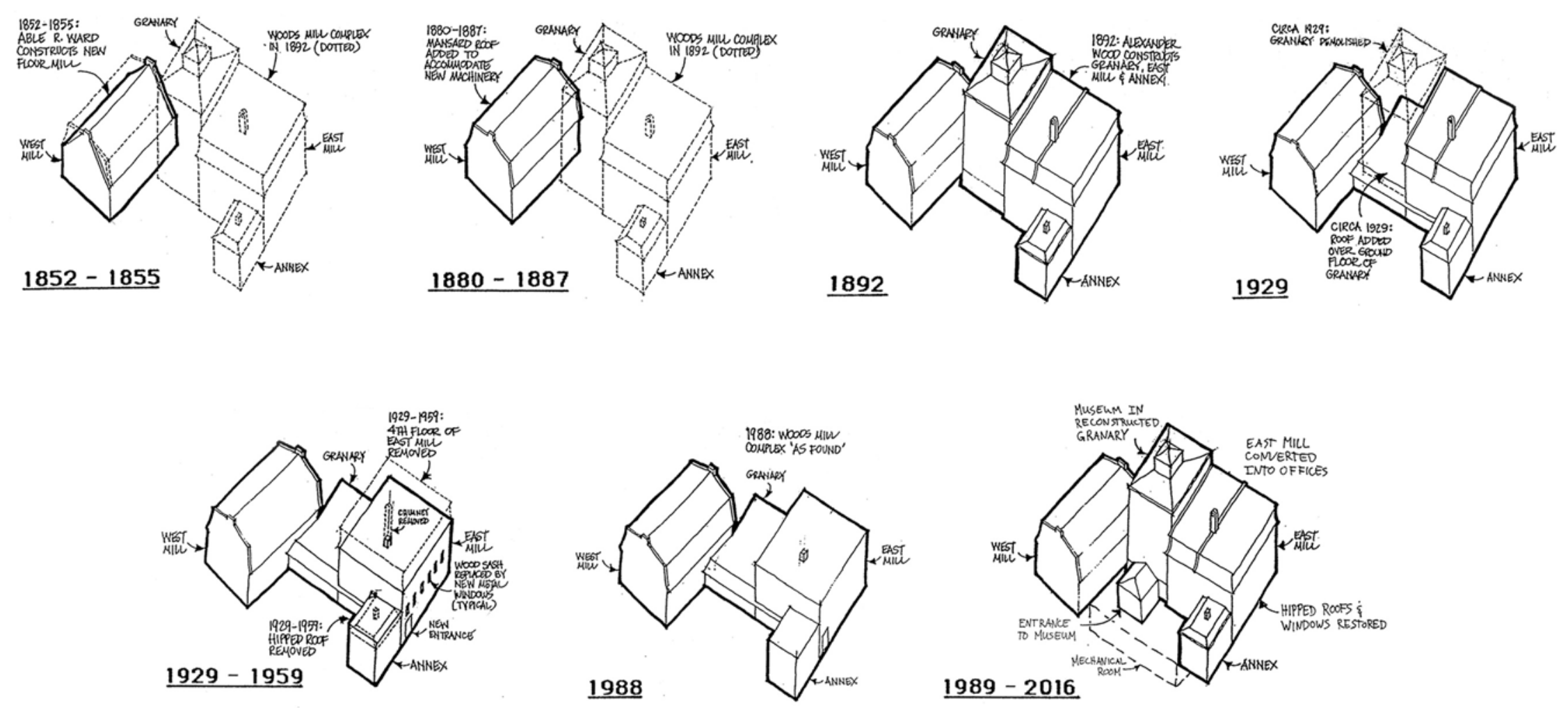
The West Mill originally used a waterwheel which was likely located in the basement near the location of the later turbine. A sluice brought water from the dam into the mill through the south wall where it turned the wheel and powered the machinery. Water exited though the north wall via the open trench tailrace. The "fast reduction" process involved three steps (cleaning, milling and bolting) where the mill stones on the ground floor were run close together to produce as much flour as possible in the first grinding. ${ }^{1}$

In 1881, Mr. Wood installed new equipment and repaired the old machinery to convert the West Mill to a large-scale flour mill. The "gradual reduction" method required five steps (cleaning, granulating, purifying, milling and bolting, then re-milling, re-purifying and rebolting) which uses a middlings purifier to separate the bran, offal and flour with air currents and bolt cloths. By running the stones higher and slower, the gluten was preserved to make a stronger flour and 1 Commonwealth Historic Resource Management Limited, 1988.

2 Ibid.

3 Ibid

4 Ibid. also higher yields of bread. Oatmeal, cornmeal, buckwheat flour and provender were also produced in the West Mill. ${ }^{2}$

The roller process, installed in 1887, used seven steps: cleaning; breaking into coarse particles (middlings); bolting stock to separate flour and middlings; purify and clean middlings; grind middlings into flour using porcelain rollers; separate grades of flour using centrifugal reels; packing and branding for various markets. In addition to improving yields and quality, the roller process was also capable of milling the harder Red Fife wheat from Manitoba which contributed to industrial urbanization in Ontario. ${ }^{3}$

Extant machinery is thought to date back to the roller process. Openings in the floors indicate the location and configuration of the chutes, elevators, belts and line shafts. ${ }^{4}$ Figure 2.6 illustrates how water used to power the milling equipment. 


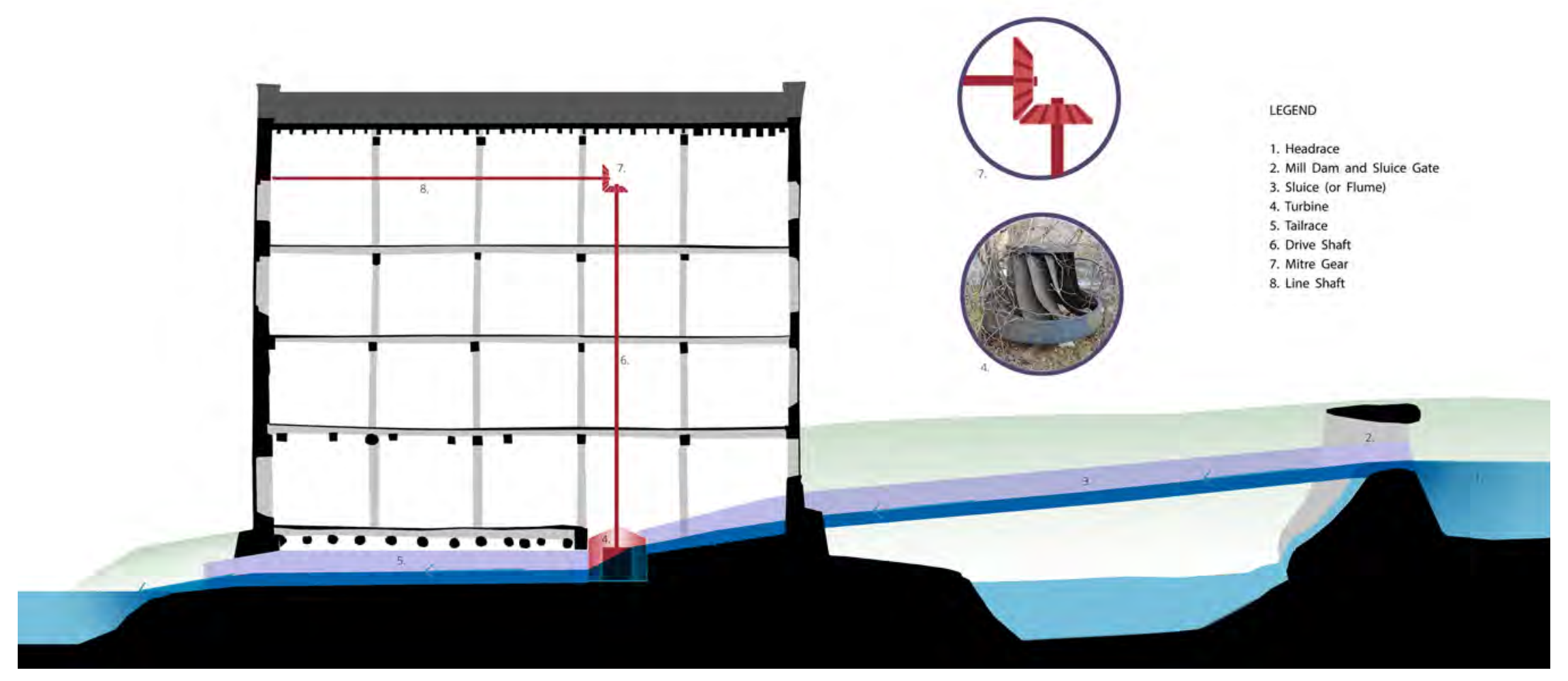




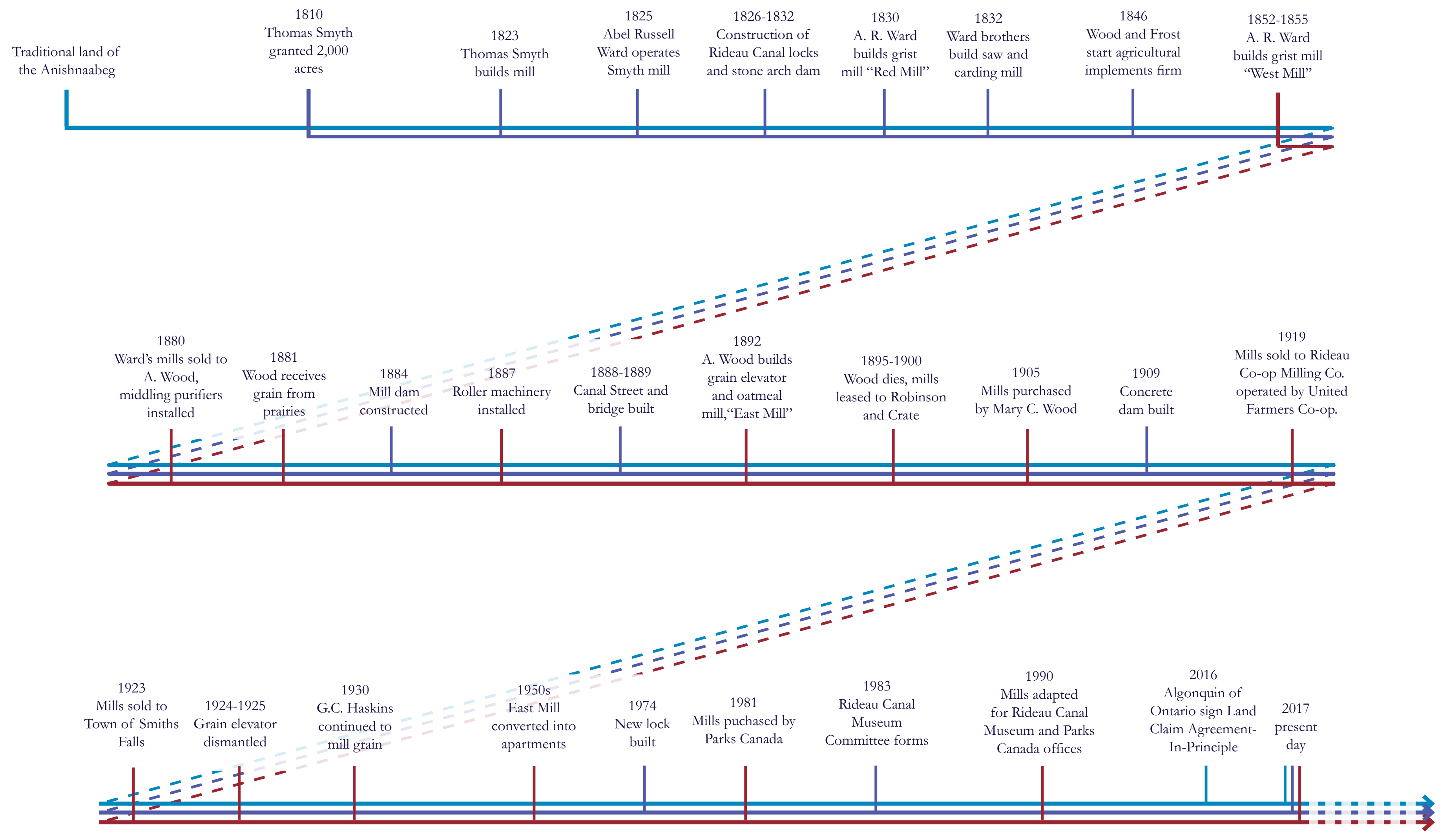




\subsection{DOCUMENT \& UNDERSTAND}

Values Analysis

At its core, heritage conservation is all about protecting and enhancing the values of the place. Values may be tangible visible elements or intangible qualities or traditions. By conserving the character-defining materials, forms, spatial configurations, uses and cultural associations of the cultural landscape, the heritage values are preserved.

Many elements within the Hornet's Snie Industrial Cultural Landscape are designated for their heritage values (figure 2.8), although the landscape as a whole is not officially recognized. The Rideau Canal World Heritage Site designation includes: the historic and replacement locks; stone arch dam; lockmaster's and canalman's houses; and a $30 \mathrm{~m}$ buffer zone. ${ }^{1}$ The East and West Mills of the Wood's Mill Complex are both recognized National Historic Sites of Canada (see appendix D). ${ }^{2}$ The Waterworks Buildings are designated at the municipal level ${ }^{3}$ and it was proposed in 2016 to add the Beckwith Street Stone Arch Bridge

1 Parks Canada, Nomination of the Rideau Canal by the Government of Canada, 2006 for Inscription on the World Heritage List (Government of Canada, 2006).

2 Canada's Historic Places, "West Mill," Canadian Register of Historic Places, 2008.

3 "Heritage Smiths Falls - Protected Properties," accessed March 24, 2017.

4 Municipal Heritage Committee, "Heritage Properties of Interest Report" (Smiths Falls, June 22, 2016).

5 Koenraad van Balen, "The Nara Grid: An Evaluation Scheme Based on the Nara Document on Authenticity," APT Bulletin 39, no. $2 / 3$ (2008): $39-45$. to the Properties of Interest Registry. ${ }^{4}$

Figure 2.9 illustrates the character-defining elements of the Hornet's Snie Industrial Cultural Landscape. Additionally, this section includes many photos of the character-defining elements of the landscape and Wood's Mill Complex. Figure 2.21 illustrates the significance of the materials of the Wood's Mill Complex.

The Nara Grid is a tool to map out the different dimensions and aspects of value which define the authenticity of heritage buildings or landscapes. ${ }^{5}$ Table 2 uses the Nara Grid to analyze the values of the entire Hornet's Snit Industrial Cultural Landscape. Table 3 uses the Nara Grid to analyze the values of the Wood's Mill Complex. Refer to Appendix A for more information on the Nara Grid. 


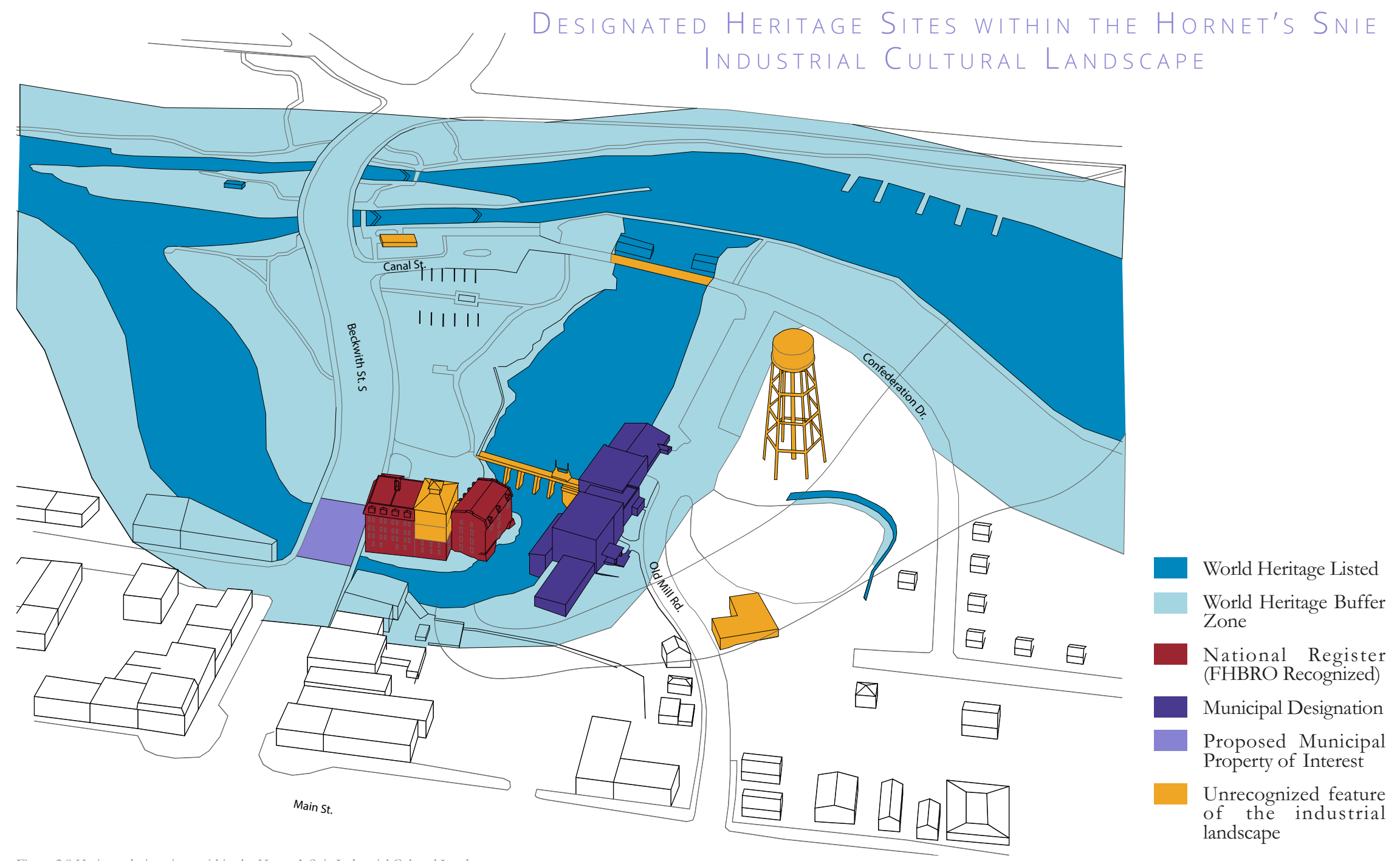




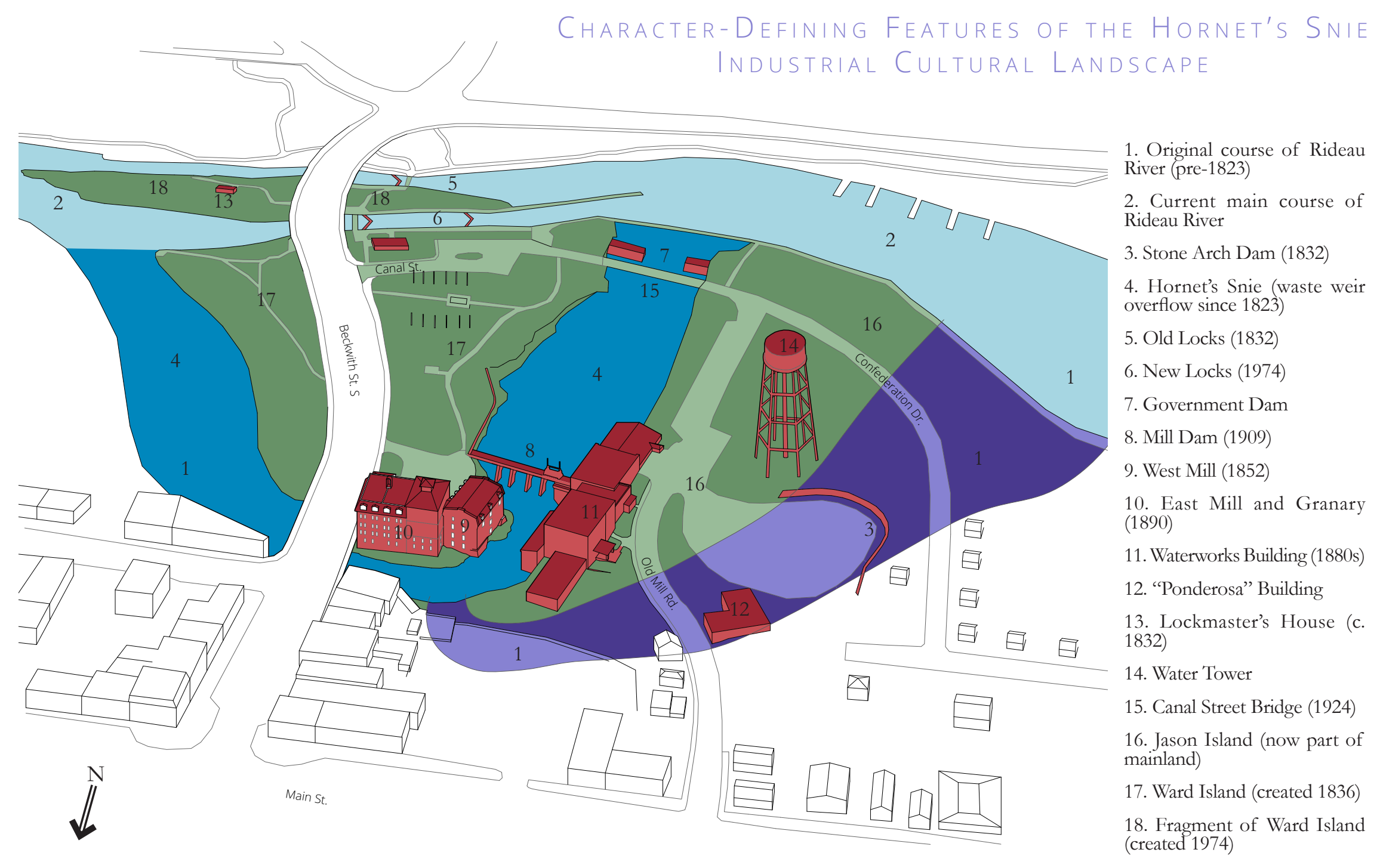

Figure 2.9 Inventory of character-defining features of the Hornet's Snie Industrial Cultural Landscape 


\begin{tabular}{|c|c|c|c|c|c|}
\hline & & \multicolumn{4}{|c|}{ DIMENSIONS } \\
\hline & & Artistic & Historic & Social & Scientific \\
\hline \multirow{6}{*}{$\begin{array}{l}\sim \\
\vdash \\
\cup \\
\sim \\
\sim \\
\leftarrow\end{array}$} & $\begin{array}{l}\text { Form \& } \\
\text { Design }\end{array}$ & $\begin{array}{l}\text { - West Mill based on } \\
\text { established vernacular and was } \\
\text { not designed by an architect }\end{array}$ & $\begin{array}{l}\text { - Alterations and additions } \\
\text { to the Wood's Mill Complex } \\
\text { reflect the changes in milling } \\
\text { technology and scale of } \\
\text { production in Canada }\end{array}$ & $\begin{array}{l}\text { - West Mill built by A. R. Ward, the } \\
\text { first permanent settler in S. Falls } \\
\text { - East Mill built by A. Wood, a } \\
\text { prominent manufacturer of farm } \\
\text { machinery }\end{array}$ & $\begin{array}{l}\text { - Construction of the locks for the } \\
\text { Rideau Canal required: the main path } \\
\text { of the river was dammed; Ward Island } \\
\text { was created; and the waste water was } \\
\text { redirected through the Hornet's Snie }\end{array}$ \\
\hline & $\begin{array}{l}\text { Materials \& } \\
\text { Substance }\end{array}$ & $\begin{array}{l}\text { - most of the industrial } \\
\text { structures have a patina } \\
\text { which enhances the nostalgic } \\
\text { qualities of the landscape }\end{array}$ & $\begin{array}{l}\text { - use of local materials for } \\
\text { construction of buildings and } \\
\text { 19th century structures }\end{array}$ & $\begin{array}{l}\text { - use of found objects in building } \\
\text { repairs such as old license plates to } \\
\text { patch holes in floor }\end{array}$ & $\begin{array}{l}\text { - the limestone } 1832 \text { lock and } \\
\text { stone arch dam has fissures which } \\
\text { compromise water levels }\end{array}$ \\
\hline & $\begin{array}{c}\text { Use \& } \\
\text { Function }\end{array}$ & $\begin{array}{l}\text { - stone arch dam and arc of } \\
\text { trees border the parking lot on } \\
\text { Jason Island }\end{array}$ & $\begin{array}{l}\text { - Aboriginal uses?? } \\
\text { - Maj. T. Smyth built first mill } \\
\text { in } 1810 \text { northwest of stone } \\
\text { arch dam } \\
\text { - owned by the United } \\
\text { Farmers of Ontario }\end{array}$ & $\begin{array}{l}-25+\text { year legal dispute between } \\
\text { millers and Ordinance over land } \\
\text { and water rights } \\
\text { - park is a social and lively place of } \\
\text { recreation }\end{array}$ & $\begin{array}{l}\text { - Jason Island re-integrated into } \\
\text { the mainland to improve access and } \\
\text { parking for the mills } \\
\text { - Rideau Canal Museum in Wood's Mill } \\
\text { Complex }\end{array}$ \\
\hline & $\begin{array}{l}\text { Tradition, } \\
\text { Techniques, } \\
\text { \& Workman- } \\
\text { ship }\end{array}$ & $\begin{array}{l}\text { - careful workmanship is } \\
\text { evident in the integration of } \\
\text { new masonry on West Mill } \\
\text { gable ends }\end{array}$ & & & - stone arch dam \\
\hline & $\begin{array}{l}\text { Location \& } \\
\text { Setting }\end{array}$ & $\begin{array}{l}\text { - industrial landscape } \\
\text { integrated with linear park } \\
\text { along entire waterfront }\end{array}$ & $\begin{array}{l}\text { - A } 11 \mathrm{~m} \text { fall of water over a } \\
400 \mathrm{~m} \text { of limestone prior to } \\
\text { canal }\end{array}$ & $\begin{array}{l}\text { - construction of the Rideau Canal } \\
\text { altered landscape and settlement } \\
\text { patterns }\end{array}$ & $\begin{array}{l}\text { - significant change in elevation mad } \\
\text { the location suitable for water power } \\
\text { and also necessary to build locks }\end{array}$ \\
\hline & $\begin{array}{l}\text { Spirit \& } \\
\text { Feeling }\end{array}$ & $\begin{array}{l}\text { - lively park contrasts with } \\
\text { the decaying, vacant and } \\
\text { overgrown structures } \\
\text { - dam in a parkinglot creates } \\
\text { a sense of mystery and } \\
\text { curiousity }\end{array}$ & $\begin{array}{l}\text { - prominent location of } \\
\text { the Wood's Mill Complex at } \\
\text { south end of downtown core } \\
\text { contributes to commercial } \\
\text { streetscape and edge of } \\
\text { industrial complex }\end{array}$ & $\begin{array}{l}\text { - Watertower, mills, dams and } \\
\text { locks are established landmarks } \\
\text { appearing in murals } \\
\text { - Water Tower visible from } \\
\text { everywhere in town }\end{array}$ & \\
\hline
\end{tabular}



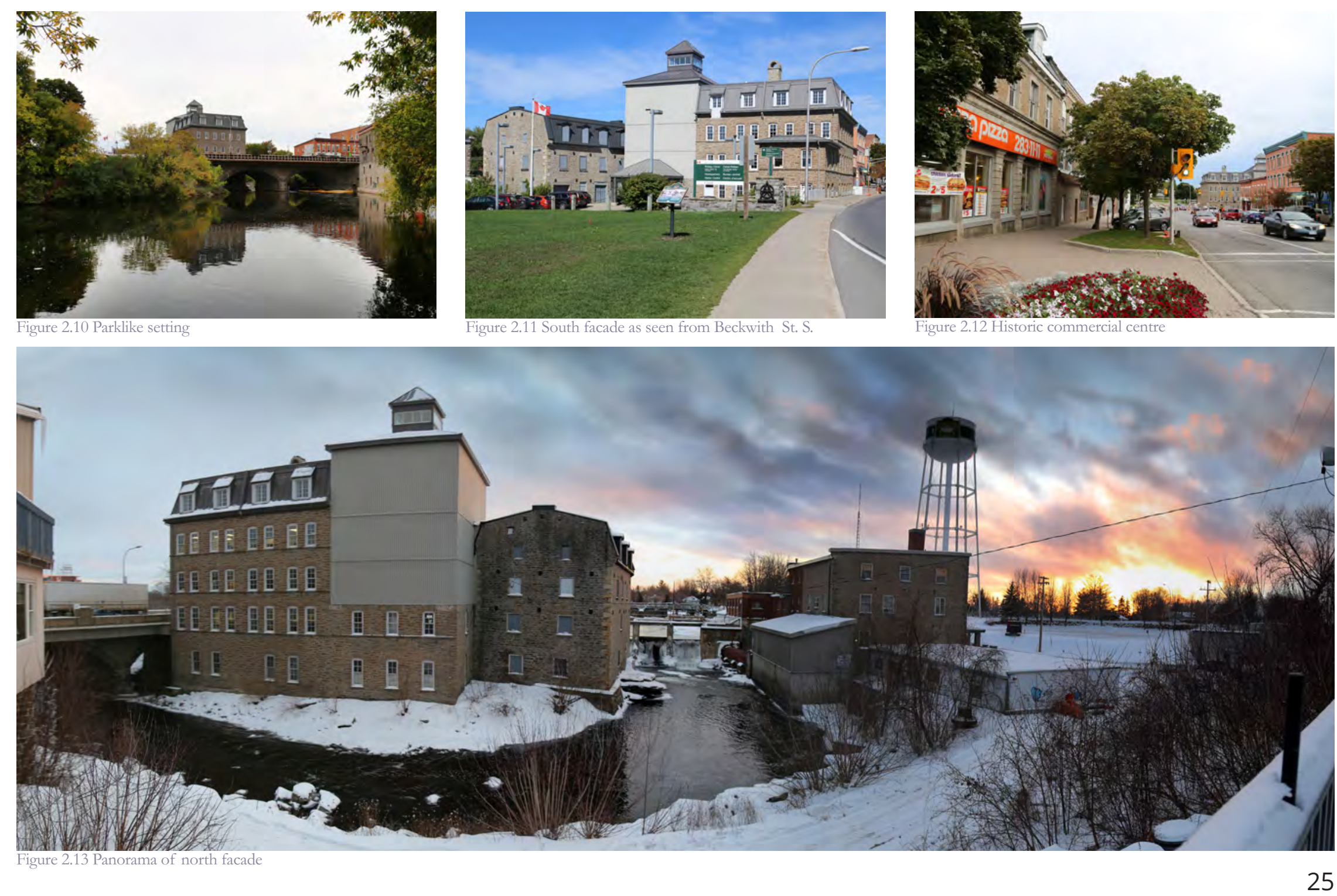

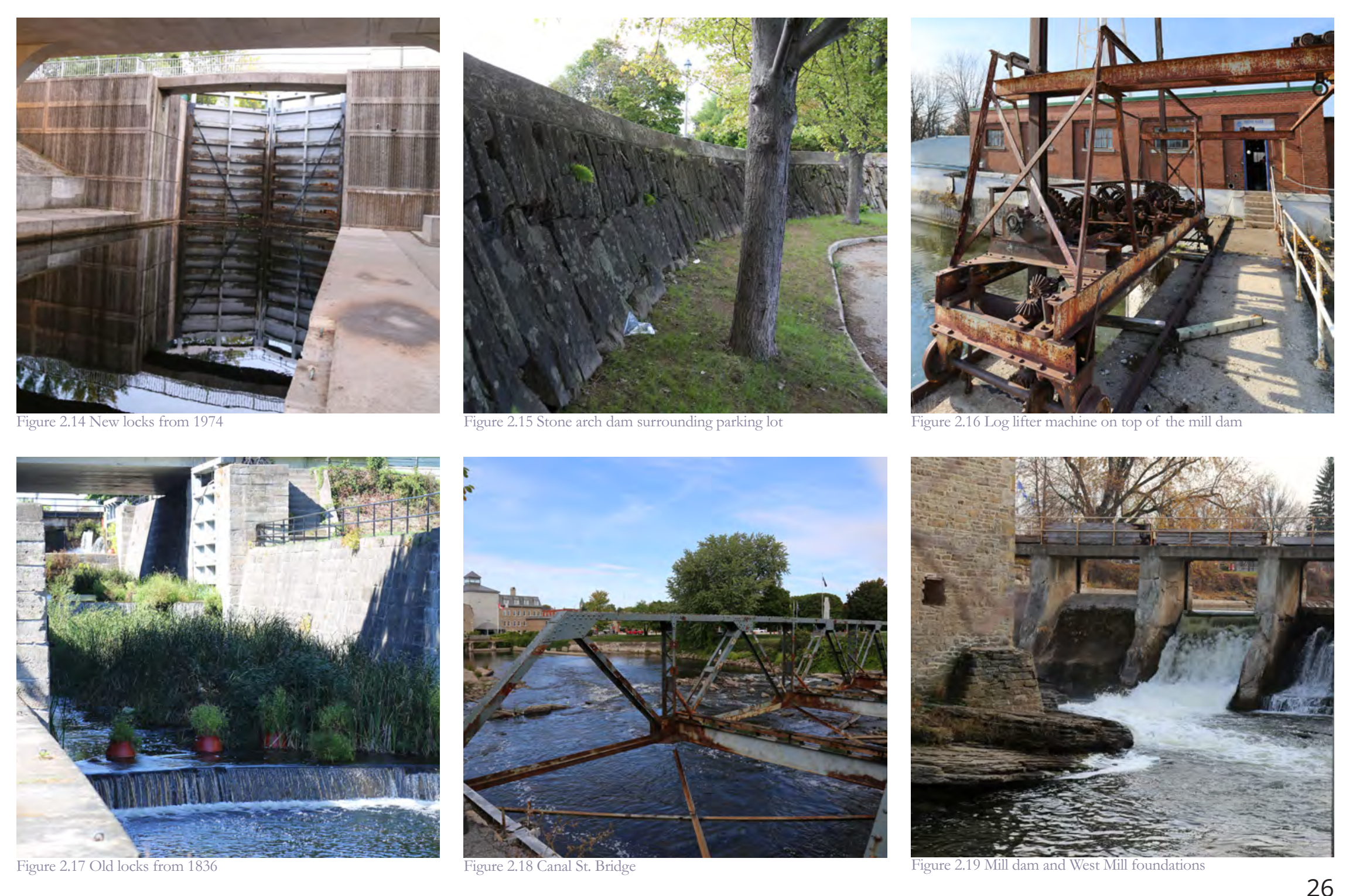


\begin{tabular}{|c|c|c|c|c|c|}
\hline & \multicolumn{4}{|c|}{ DIMENSIONS } \\
\hline & & Artistic & Historic & Social & Scientific \\
\hline \multirow{6}{*}{$\begin{array}{l}\sim \\
\vdash \\
\cup \\
\square \\
\sim \\
\leftarrow\end{array}$} & $\begin{array}{l}\text { Form \& } \\
\text { Design }\end{array}$ & $\begin{array}{l}\text { - two-and-a-half storey massing } \\
\text { - rare mansard roofs } \\
\text { - gable roofed dormers } \\
\text { - West Mill based on established } \\
\text { vernacular, no architect }\end{array}$ & $\begin{array}{l}\text { - West Mill roof converted from } \\
\text { gable to mansard in } 1887 \text { with } \\
\text { parapets and corbelled eaves. }\end{array}$ & $\begin{array}{l}\text { - West Mill built by Abel } \\
\text { Russell Ward, the first } \\
\text { permanent settler of Smiths } \\
\text { Falls } \\
\text { - East Mill built by } \\
\text { Alexander Wood, a } \\
\text { prominent manufacturer of } \\
\text { farm machinery }\end{array}$ & $\begin{array}{l}\text { - enlarged dormer on east } \\
\text { facade of West Mill for hoisting } \\
\text { grain } \\
\text { - interior layout and additional } \\
\text { structural elements for } \\
\text { machinery }\end{array}$ \\
\hline & $\begin{array}{l}\text { Materials \& } \\
\text { Substance }\end{array}$ & $\begin{array}{l}\text { - exterior limestone walls } \\
\text { - wood casement and double hung } \\
\text { windows }\end{array}$ & $\begin{array}{l}\text { - millstone technology followed by } \\
\text { roller-milling technology }\end{array}$ & $\begin{array}{l}\text { - calculations written on } \\
\text { structure } \\
\text { - use of found materials } \\
\text { such as old license plates to } \\
\text { patch holes in floor }\end{array}$ & $\begin{array}{l}\text { - openings cut into the floors } \\
\text { for flumes and belts }\end{array}$ \\
\hline & $\begin{array}{l}\text { Use \& Func- } \\
\text { tion }\end{array}$ & & $\begin{array}{l}\text { - closely related to evolution of } \\
\text { grain milling in Canada from small } \\
\text { scale pioneer to larger merchant } \\
\text { mills }\end{array}$ & $\begin{array}{l}\text { - owned by the United } \\
\text { Farmers of Ontario } \\
\text { cooperative from 1919-1923, } \\
\text { a political party in Ontario }\end{array}$ & $\begin{array}{l}\text { - West Mill basement used a } \\
\text { water powered turbine from } \\
1880 \mathrm{~s}\end{array}$ \\
\hline & $\begin{array}{l}\text { Tradition, } \\
\text { Techniques, } \\
\text { \& Workman- } \\
\text { ship }\end{array}$ & $\begin{array}{l}\text { - careful workmanship is evident in } \\
\text { the integration of new masonry on } \\
\text { West Mill gable ends }\end{array}$ & & $\begin{array}{l}\text { - West Mill } 1881 \text { renovation } \\
\text { done by Matthew Ryan, } \\
\text { prominent builder of public } \\
\text { buildings and residences in } \\
\text { Smiths Falls }\end{array}$ & \\
\hline & $\begin{array}{l}\text { Location \& } \\
\text { Setting }\end{array}$ & $\begin{array}{l}\text { - picturesque location within the } \\
\text { Hornet's Snie industrial cultural } \\
\text { landscape }\end{array}$ & $\begin{array}{l}\text { - powered by the water from the } \\
\text { waste weir of the lockstation } \\
\text { - west and north facades adjacent to } \\
\text { waste weir and remain unchanged } \\
\text { from } 1890 \text { s }\end{array}$ & $\begin{array}{l}\text { - prominent location at } \\
\text { south end of downtown } \\
\text { core contributes to } \\
\text { commercial streetscape and } \\
\text { edge of industrial complex }\end{array}$ & $\begin{array}{l}\text { - manipulation of water flow } \\
\text { for locks, industrial mill races } \\
\text { - stone arch dam }\end{array}$ \\
\hline & $\begin{array}{l}\text { Spirit \& Feel- } \\
\quad \text { ing }\end{array}$ & $\begin{array}{l}\text { - Ward's Island south of the } \\
\text { complex is landscaped and } \\
\text { integrated into park as part of } \\
\text { recreational development of } \\
\text { Rideau Canal }\end{array}$ & $\begin{array}{l}\text { - north and east facades part of the } \\
\text { urban character of the downtown } \\
\text { core }\end{array}$ & $\begin{array}{l}\text { - an established local } \\
\text { landmark and appears } \\
\text { in murals, posters, and } \\
\text { promotional materials for } \\
\text { Smiths Falls }\end{array}$ & \\
\hline
\end{tabular}




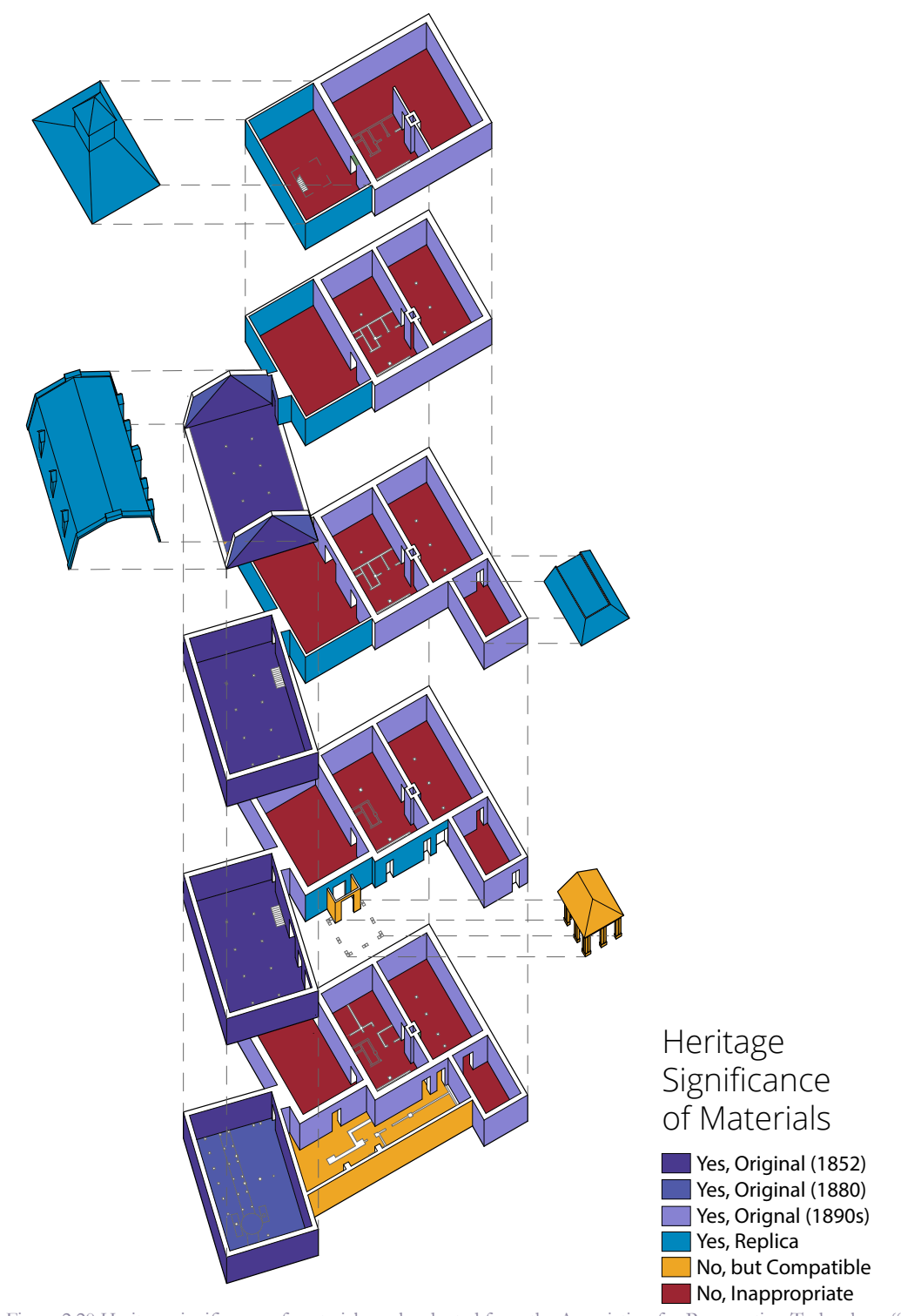



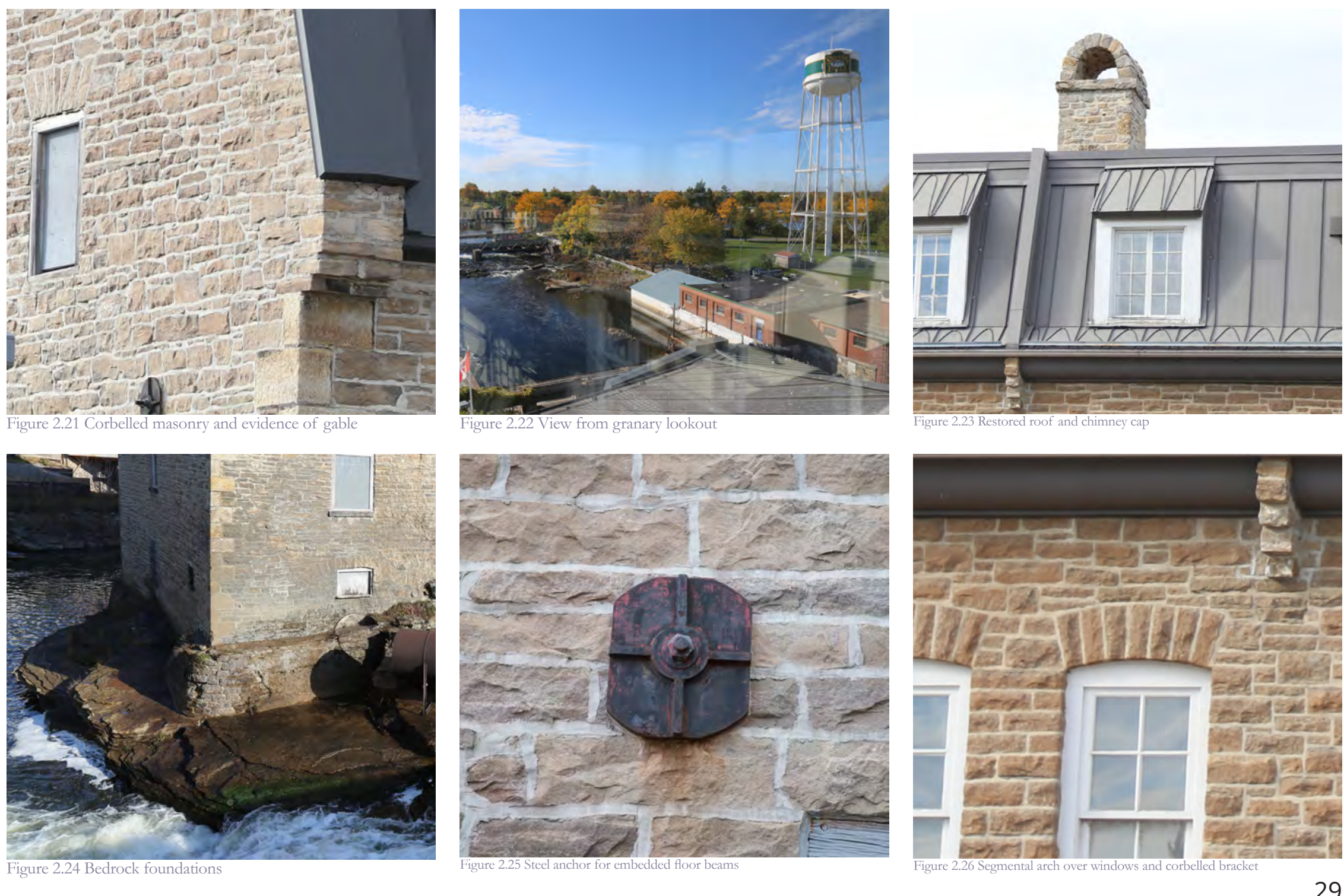

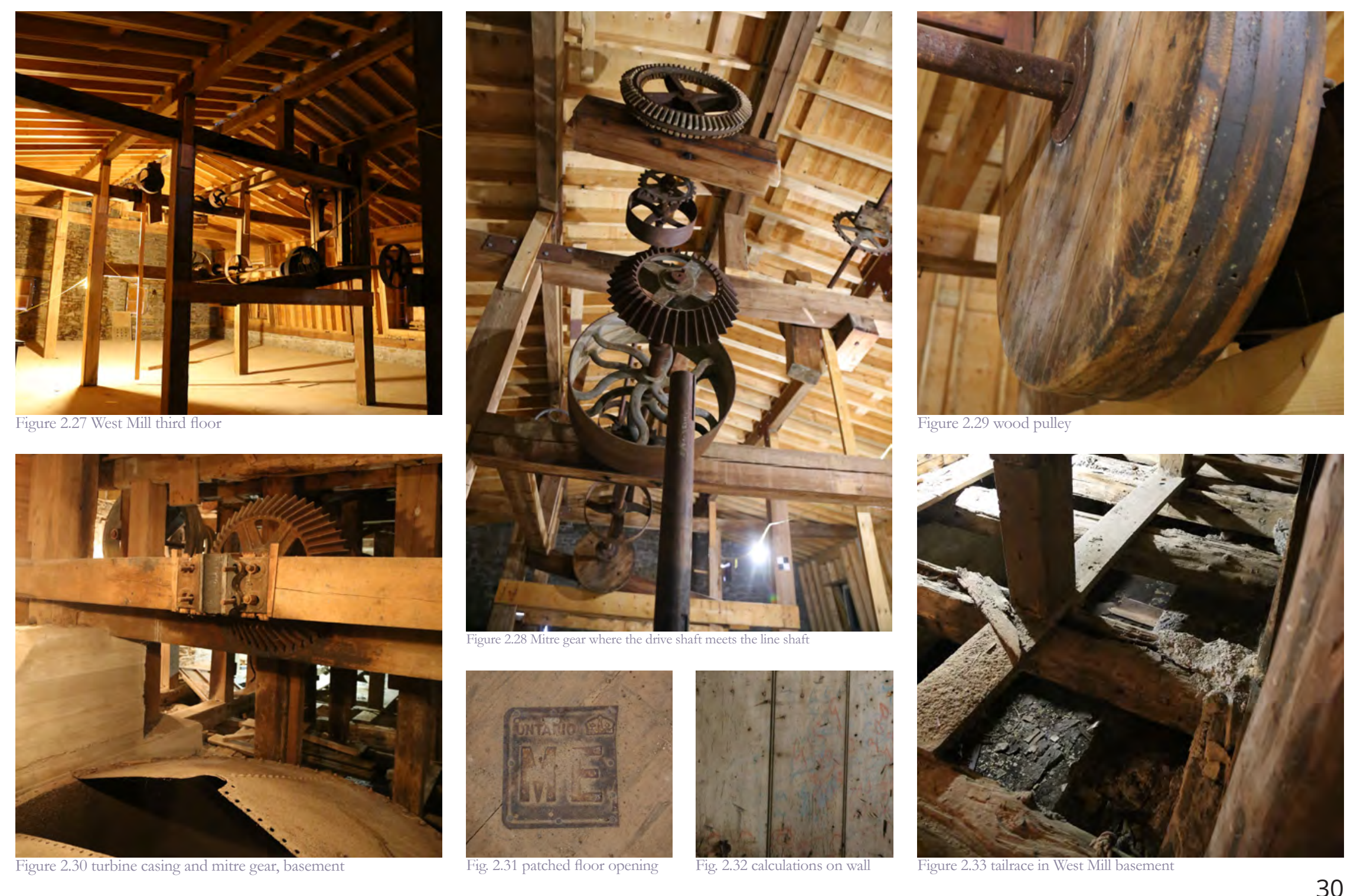


\subsection{DOCUMENT \& UNDERSTAND}

\section{SURVEY}

The Dublin Principles emphasize documentation and understanding of the site, because to understand why and how an individual structure was built the way it was, it is essential to understand the landscape in its entirety. In the case of the Hornet's Snie industrial cultural landscape, the mills were built in response to the engineering works which were built as a response to the topography.

In addition to photography, the a point cloud was created using creation of a point cloud through laser scan and photogrammetric data. See Appendix E for more information about the documentation workflow.
Although limited in accuracy, the resulting point cloud is useful in visualizing the relationship between the Wood's Mill Complex, the Hornet's Snie, and the topography. This relationship is essential to understanding why the landscape was modified the way it was and how the water was harnessed to power the equipment. Taking sections through the West Mill revealed the alignment of the remaining equipment on the third floor to the turbine in the basement, as well as deflections in the structure. Figures 2.34, 2.35, and 2.36 are the result of tracing over the point clouds. 


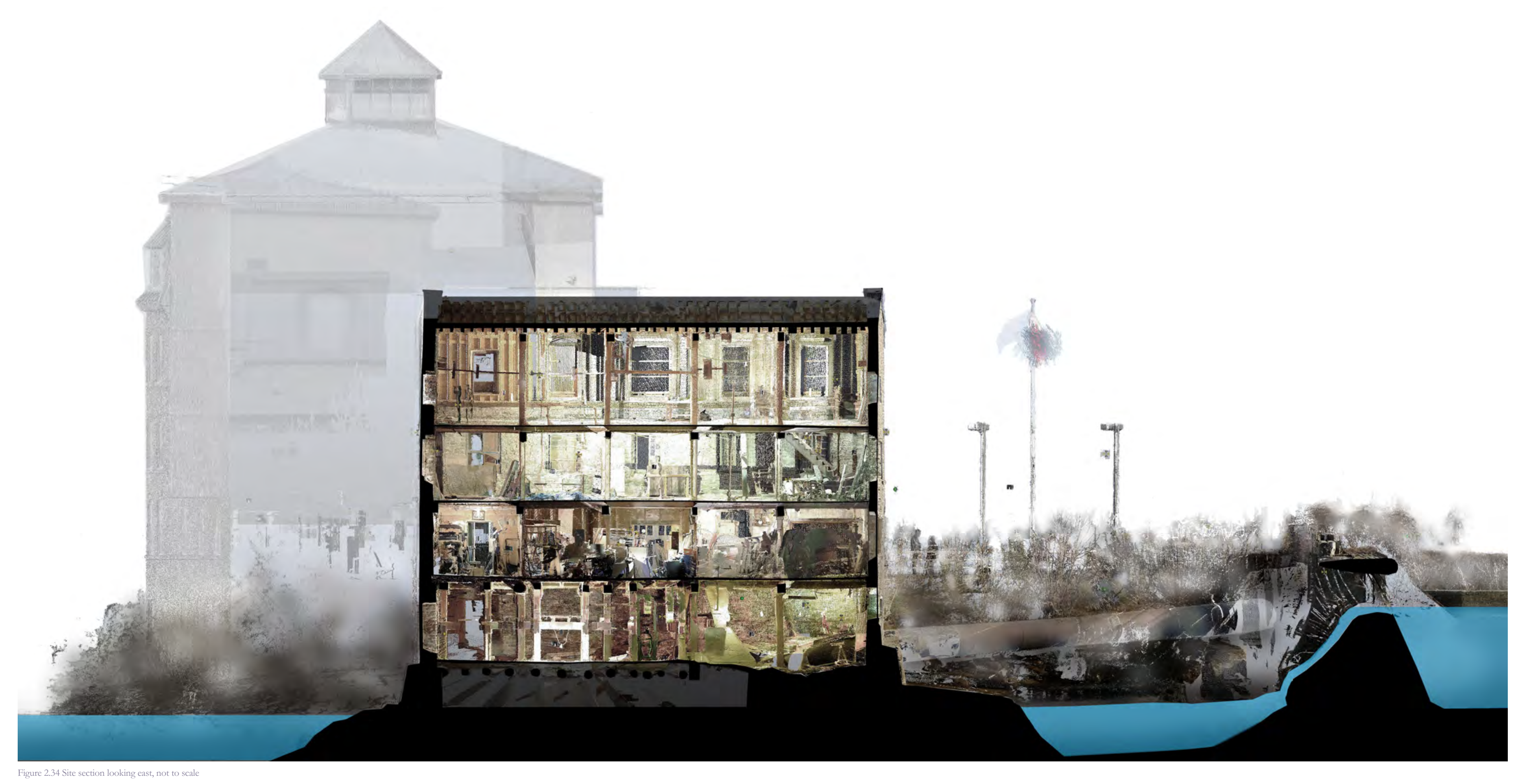




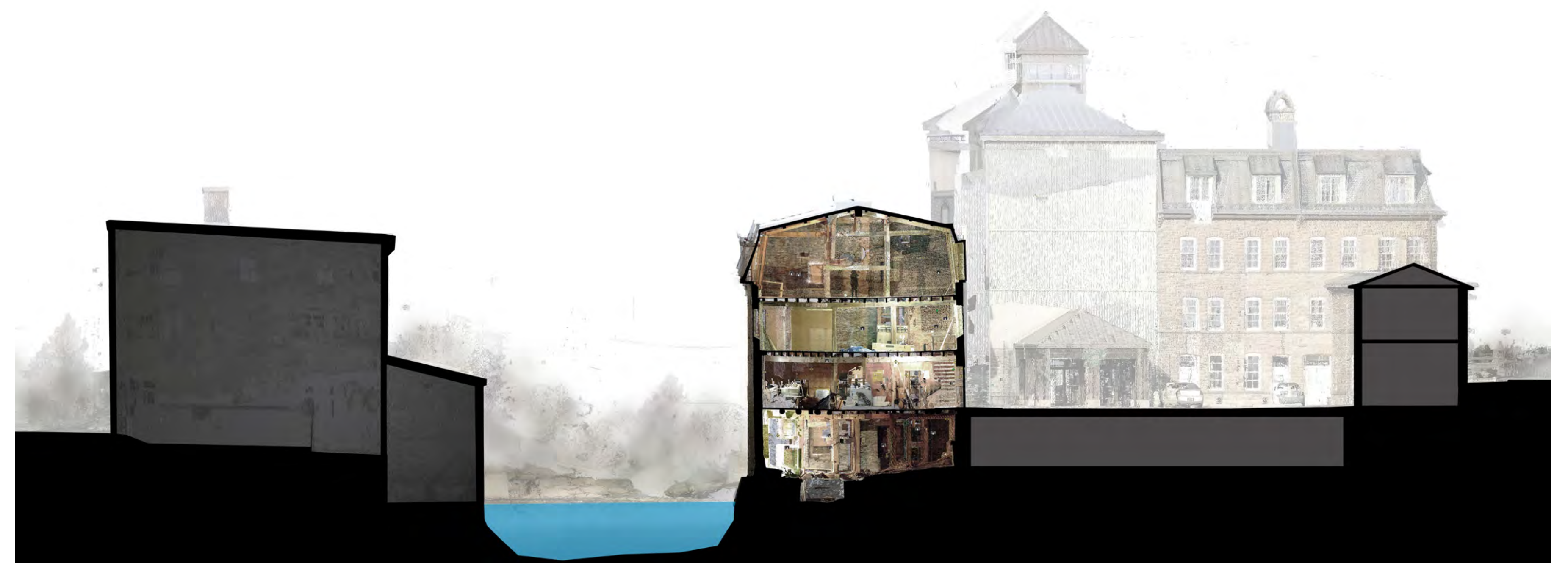




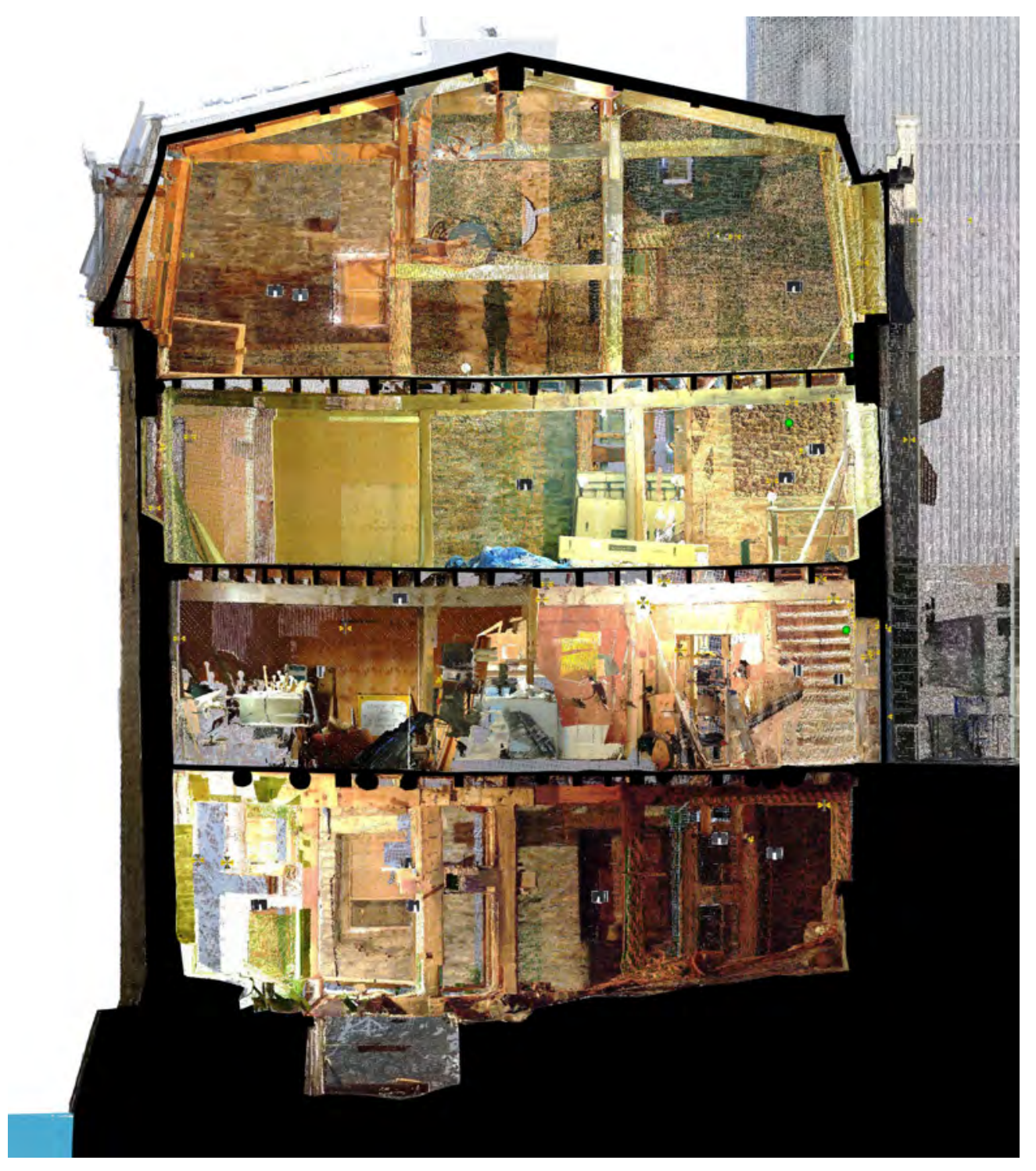




\section{Existing Conditions}

A basic preliminary condition assessment was conducted for the Wood's Mills Complex by means of visual inspection and infrared thermography. Scope of the investigation was mainly limited to the exterior of the complex and the interior of the West Mill. Overall, the buildings appear to be good condition. This section of the report focuses on the observations which influence the project design decisions, including opportunities to improve sustainable performance.

Although the structure was recently stabilized, the columns of the West Mill are not aligned and the floors show deflections of approximately $10 \mathrm{~cm}$. Also, there are numerous holes in the floors (approximately $15 \mathrm{~cm}$ by $15 \mathrm{~cm}$ ) due to past configurations of milling equipment. See figures 2.37 and 2.38 .

Plaster is peeling off of the interior of the masonry walls, likely due to moisture damage. It is assumed that the source of moisture has been eliminated with the installation of a new roof in 2010. Parks Canada employees observed that some of the offices are very cold in the winter and very hot in the summer, likely due to the exposed masonry walls. Interior insulation was installed in the East Block in one area on the south façade by the exit stairs. The insulated masonry appears to be in equally good condition as the uninsulated. This is discussed more in Appendix F. See figures 2.39 and 2.40.

The West Mill has not been heated for many years and there is no insulation in the roof. Thermography reveals that air seems to be leaking out of the joints in the corrugated metal façade of the granary and from the roof of the East Mill. See figures 2.41, 2.42 and 2.43.

Conditions observed in the surrounding industrial landscape include: severe corrosion of the Canal Street steel truss bridge (figure 2.19); spalled concrete of the mill dam (figure 2.20); displaced retaining walls (figure 2.46); and overgrown culvert near the Waterworks Building. Also, the "Ponderosa Building" has many open joints, spalled and displaced masonry likely to due differential settlement seemingly caused by water flowing underground (figures 2.46 and 2.47). 

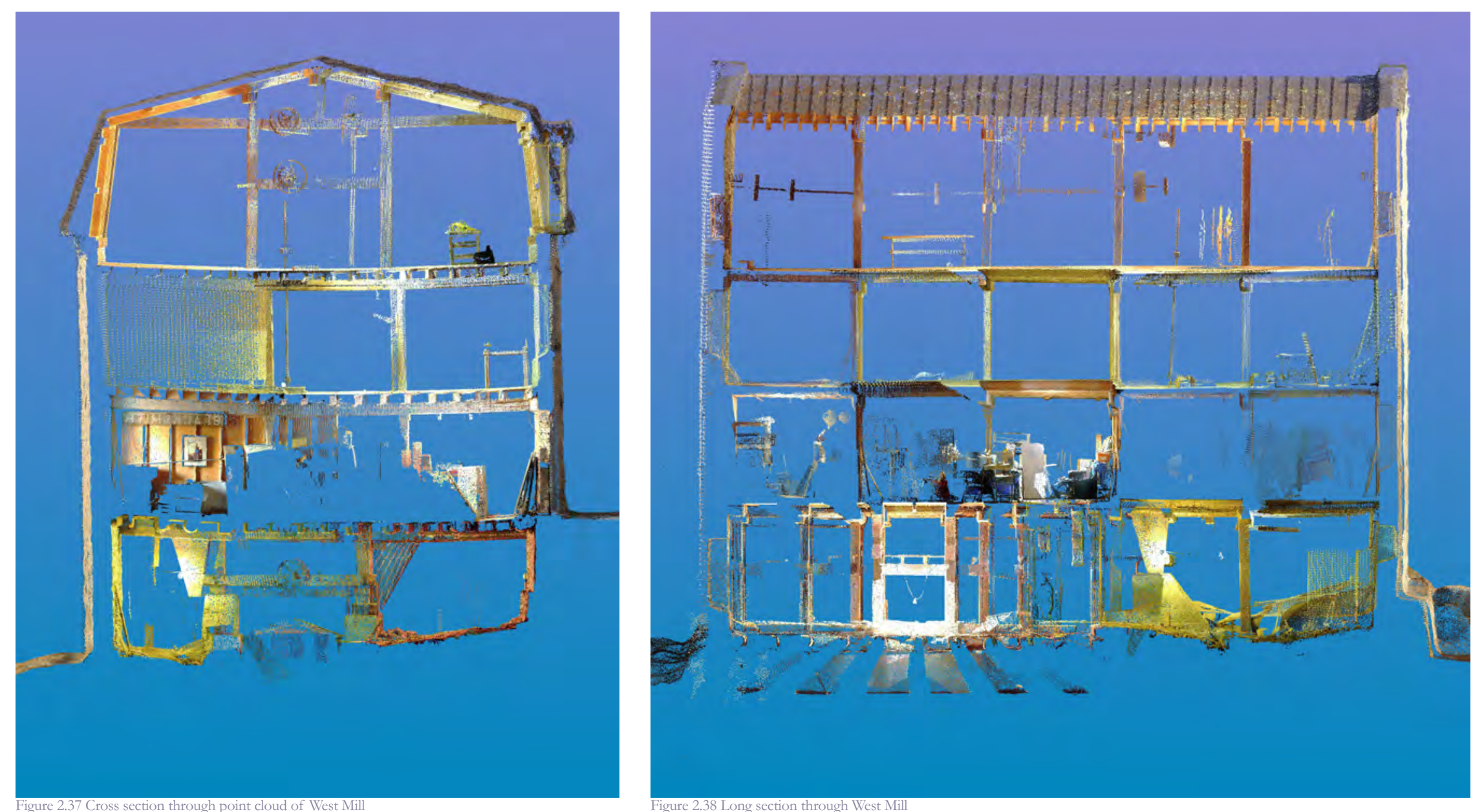

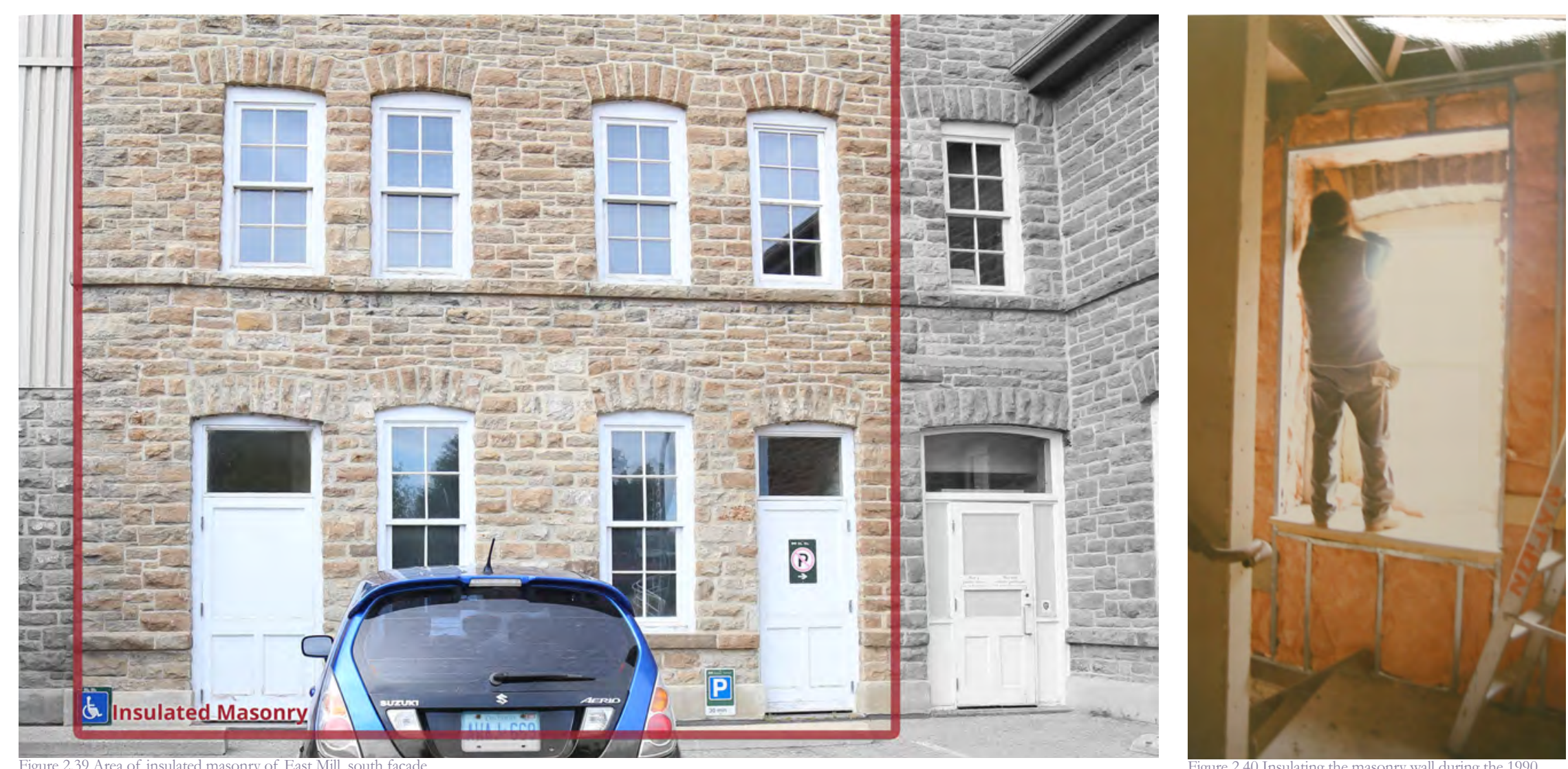

rehabilitation. Credit: Barry Padolsky Associates Inc., 1990 

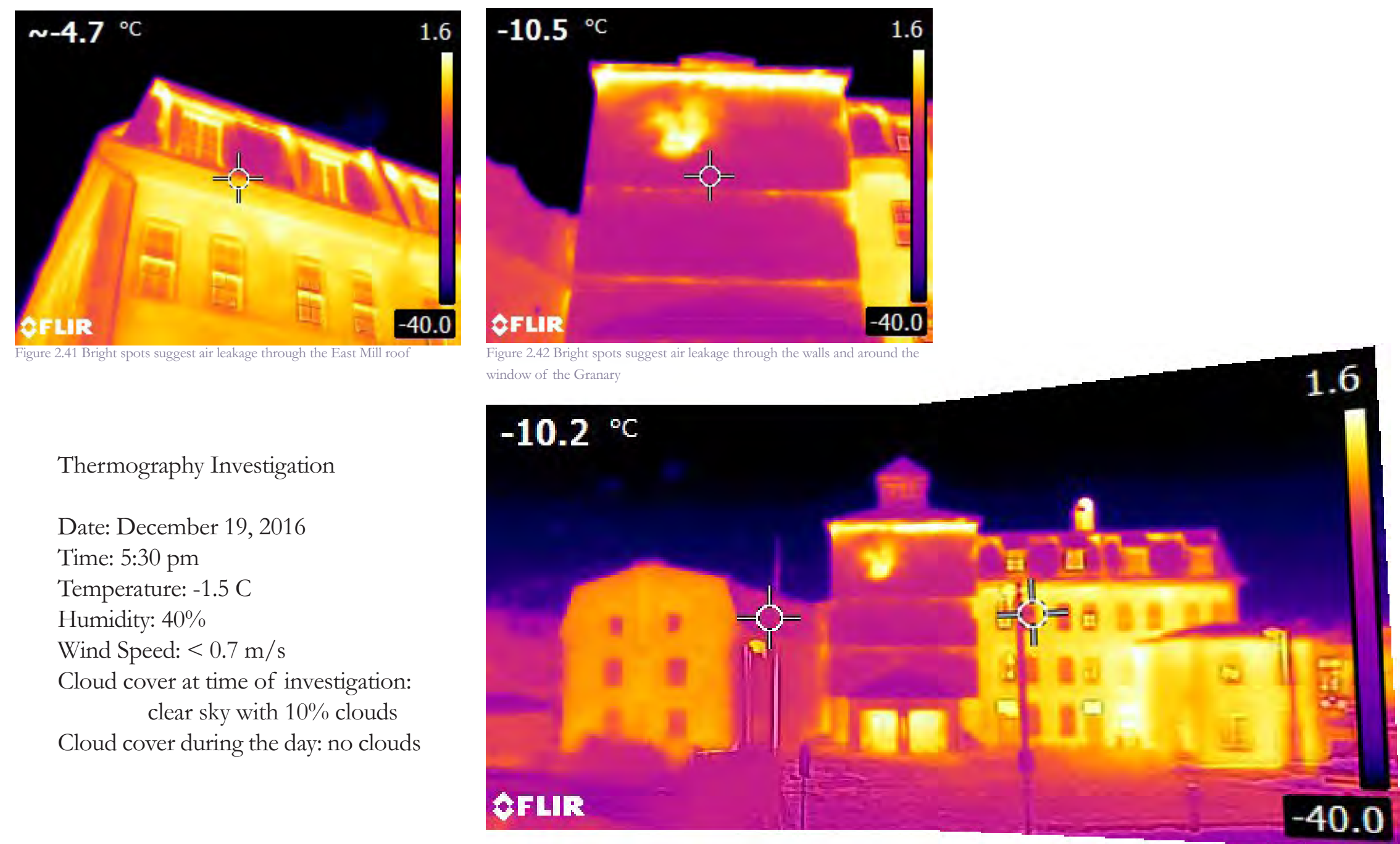

Date: December 19, 2016

Time: 5:30 pm

Temperature: $-1.5 \mathrm{C}$

Humidity: $40 \%$

Wind Speed: $<0.7 \mathrm{~m} / \mathrm{s}$

Cloud cover at time of investigation: clear sky with $10 \%$ clouds

Cloud cover during the day: no clouds 


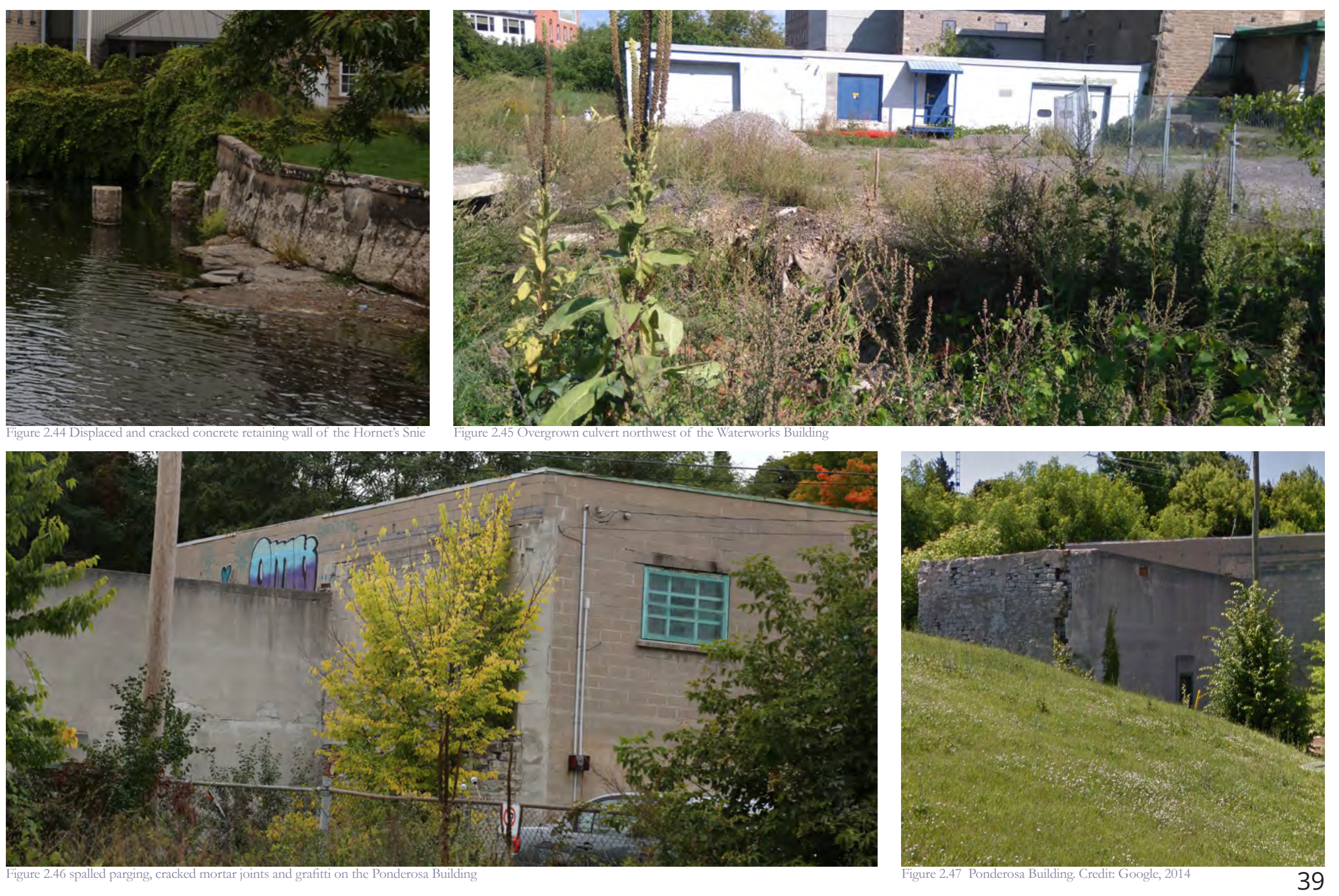


3.

Plan to Protect \& Conserve 
Concept: Regenerating the Heart

Water is the lifeblood of the Rideau Canal. ${ }^{1}$ And the Mill is the heart of the town. In the beginning, it harnessed water to provide food and timber to the early settlers. The village grew up around the mill because it was the source - it pumped life, energy and ingenuity into its surroundings.

The heart pumps blood along the pulmonary circuit to exchange carbon dioxide for oxygen and then through the systemic circuit to deliver oxygen to the rest of the body so it can function. If someone only inhales, they drown. If they only exhale, they suffocate. In the same way that the circulatory system requires this dynamic balance, a healthy community must give and take, lead and serve; it must sustain locals and reach out to visitors (figures 3.1 and 3.2).
Culture arises from these daily exchanges, from interaction between people which promotes well-being and creativity. Furthermore, addressing the needs of the locals promotes social equity while providing a destination for visitors increases material prosperity through a more diverse economy. The natural environment is sustained by adapting historic buildings to support contemporary values and needs. Striving to enhance these dimensions or pillars of sustainability encourages innovation and promotes resilience. "An innovative society is openminded, curious, compassionate and lively; it respects and embraces difference. In so being, it is able to meet every challenge and adapt to changing circumstances."

1 Kim Whytock \& Associates Inc., "Rideau Canal Heritage Corridor Visitor Experience Opportunities Concept: Executive Summary," 2013.

2 Hawkes, 2001. 

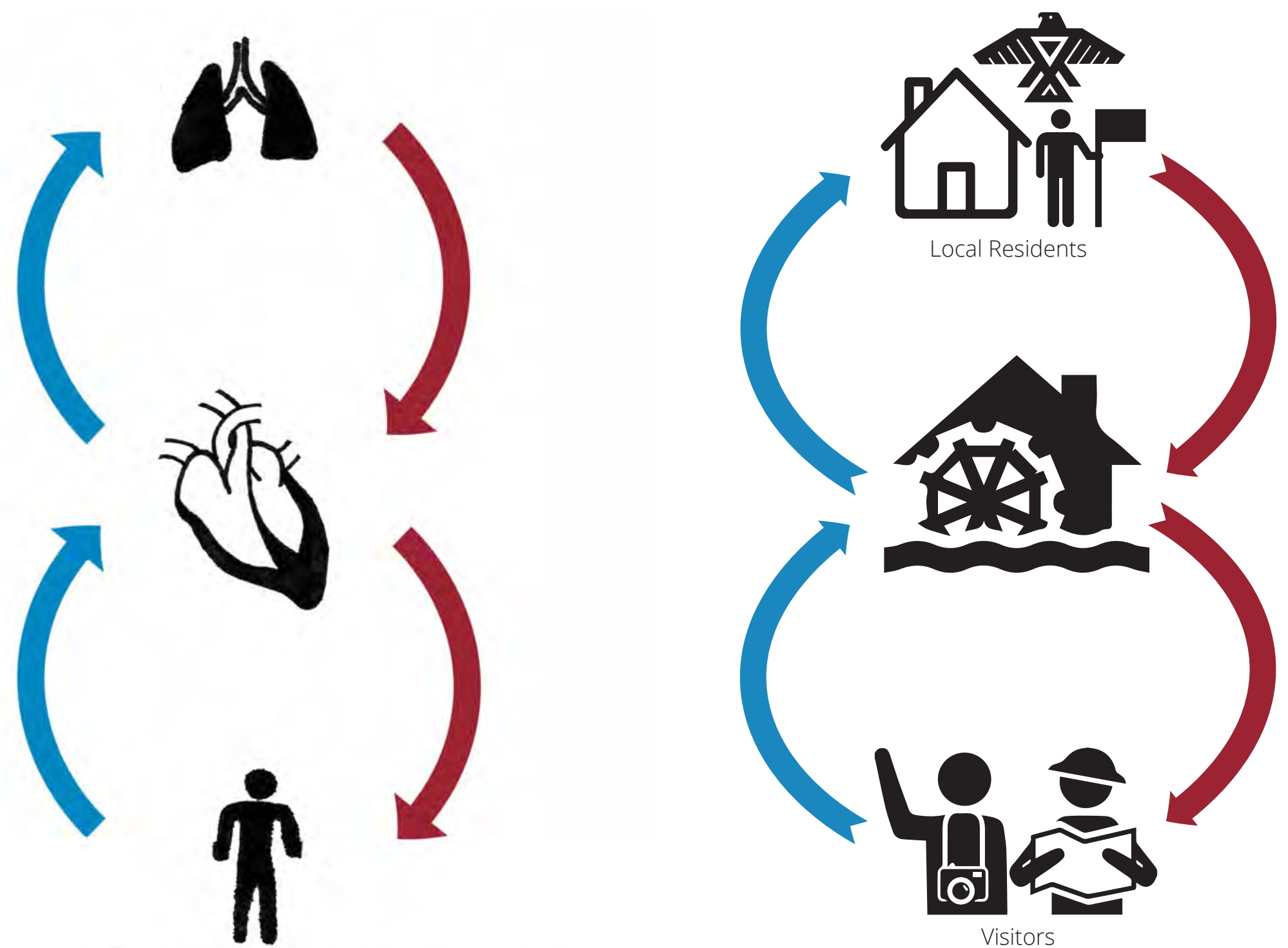


\section{Design Strategies: Circulation \& Access}

Located at the edge of an island surrounded by water on two sides and a busy highway on the other, accessibility and parking have always been a challenge for the site. Restoring the Canal Street bridge for vehicular use; adapting the mill dam for pedestrians; and expanding the existing pedestrian network running through Smiths Falls' waterfront encourages people to pause and explore the Wood's Mills Complex as seen in figure 3.3.

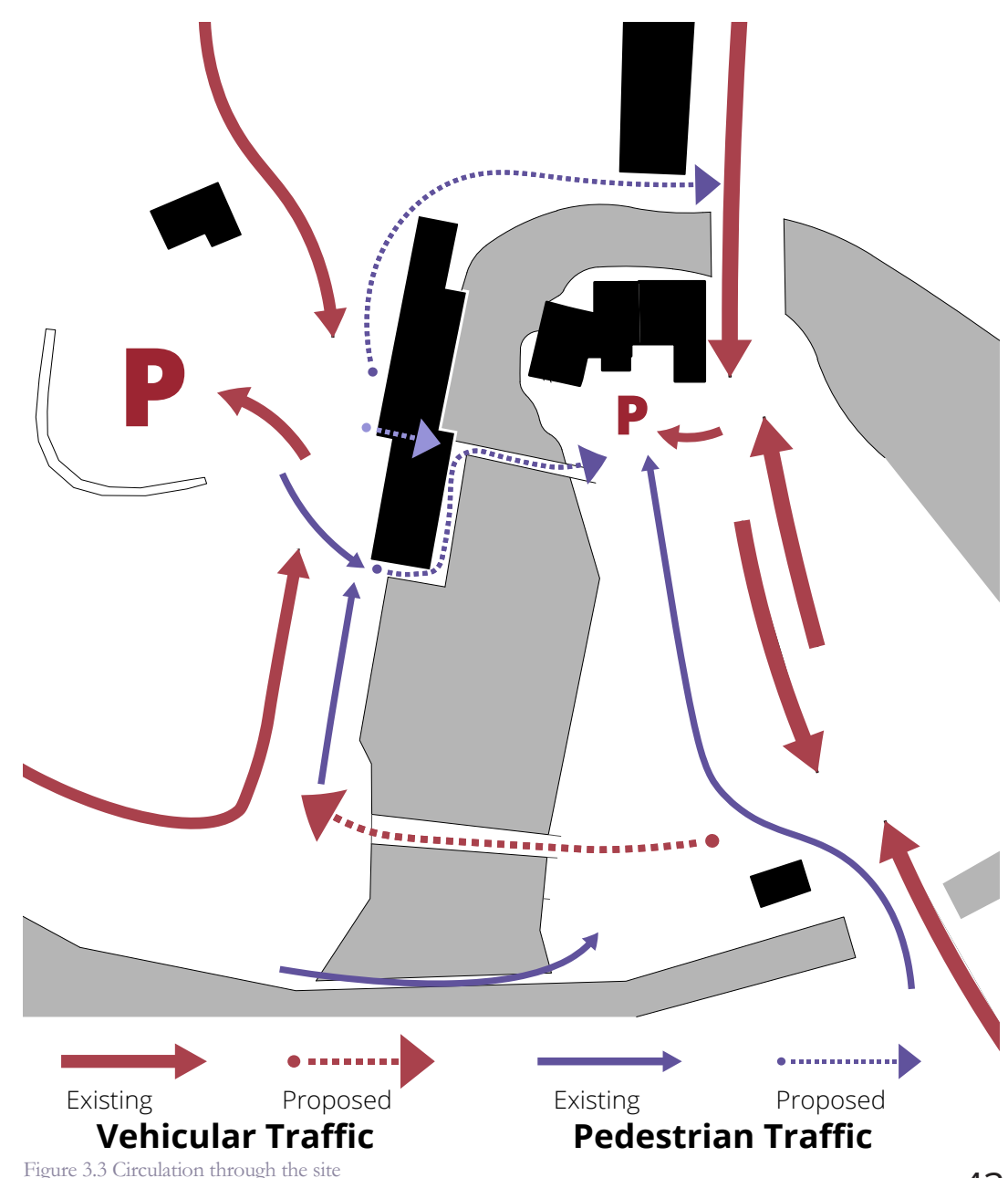




\section{Design Strategies: Movement of Water}

Falling water is the reason why it was here that the mills, locks, dams and town were built; the reason why Smiths Falls became the industrial centre of the region. Honouring this movement of water is a central theme to the design. Rainwater captured from the roofs and parking lots is funneled over the main entrance into a series of gullies, swales and stormwater planters where it is filtered before re-entering the river.

Water is diverted from the main branch of the Rideau Canal into the headrace. Via the penstock, it enters the West Mill where it generates electricity by flowing through the turbine. Then the water exits the building through the tailrace to rejoin the Hornet's Snie.
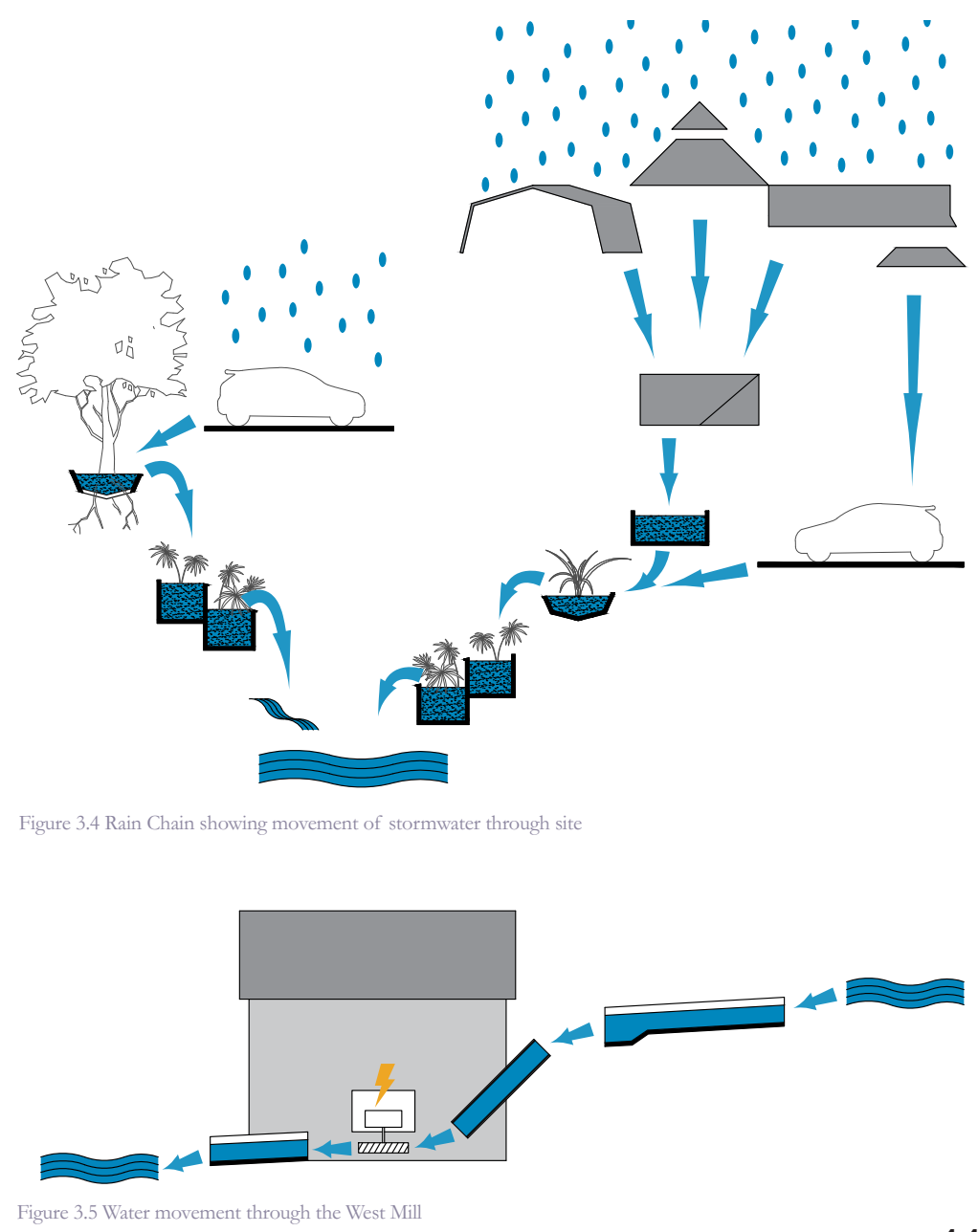


\section{Design Strategies: Materials}

The reflective, translucent and vertical qualities of falling water guide the choice of new materials in the design. Channel glass (figure 3.6) is used for interior partitions. The Granary is clad in highly reflective glass curtain wall and spandrel panels with exterior wood louvers (figure 3.8). Instead of downspouts, local artists can create decorative rain chains and sculptures which feature the movement of water (figure 3.7). All these elements can be enhanced with accent lighting.

Eastern white cedar is the preferred wood in exterior and interior applications because of its durability, significance to indigenous people and can be sourced locally.
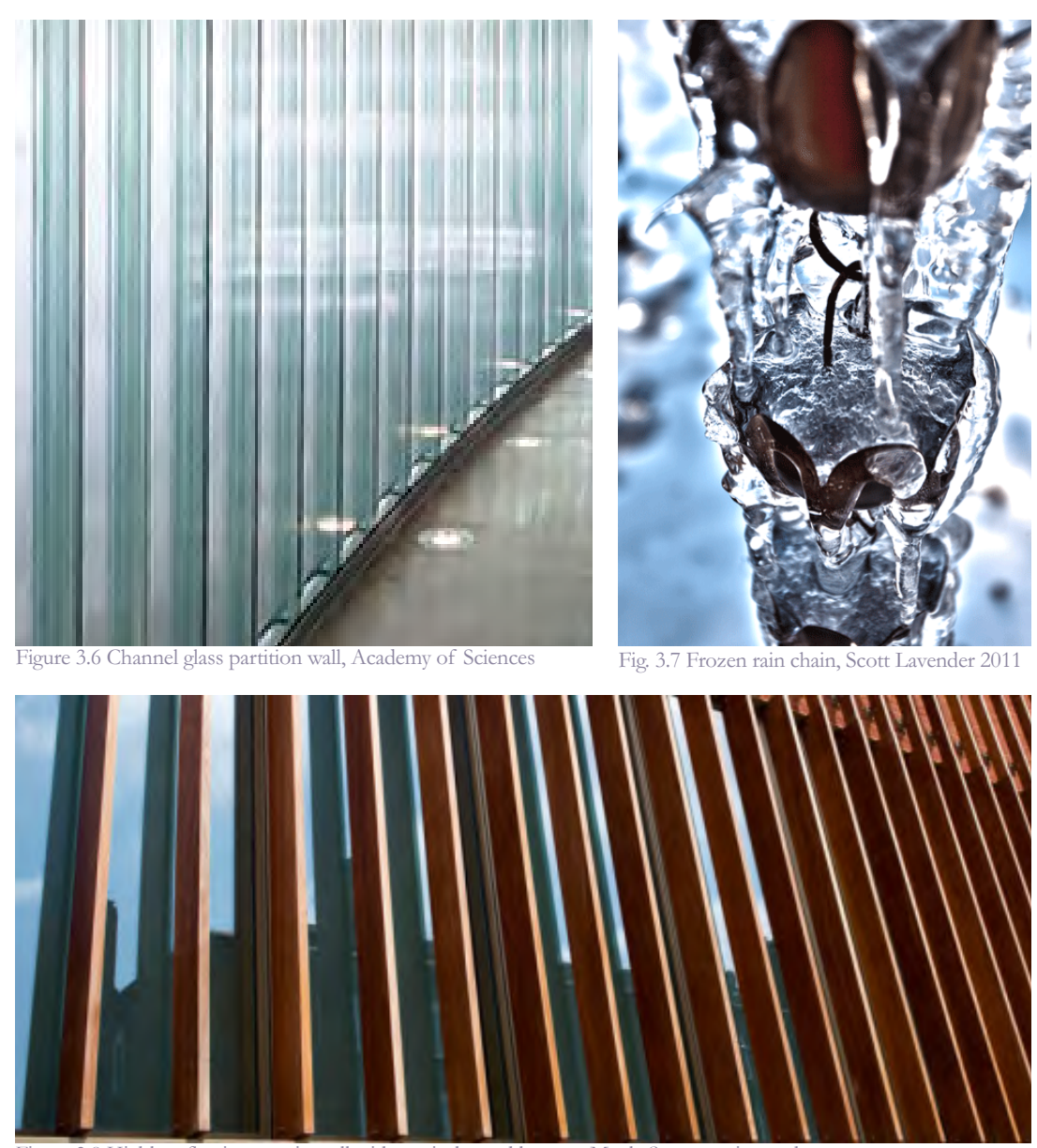


\section{Design Strategies: InCRementalism}

Given the size and complexity of the site, an incremental "phased" approach to development allows the project to adapt and grow with the town. A phased approach is cost effective, reduces risk of the capital investment, and is easier to manage. Additionally, it allows the project to integrate better into the social and cultural identity of the community. The first phase is adapting the West Mill and granary for community use and reorganizing the museum (figure 3.8, dark purple). The mill dam and Canal St. bridge would need to be rehabilitated at this time to meet parking requirements. Subsequent phases (order to be determined based on community needs) include: expanding community and museum functions into the East Mill; hydroelectric power in West Mill; other landscaping interventions; development or deconstruction of the Ponderosa Building and development of the Waterworks Building.

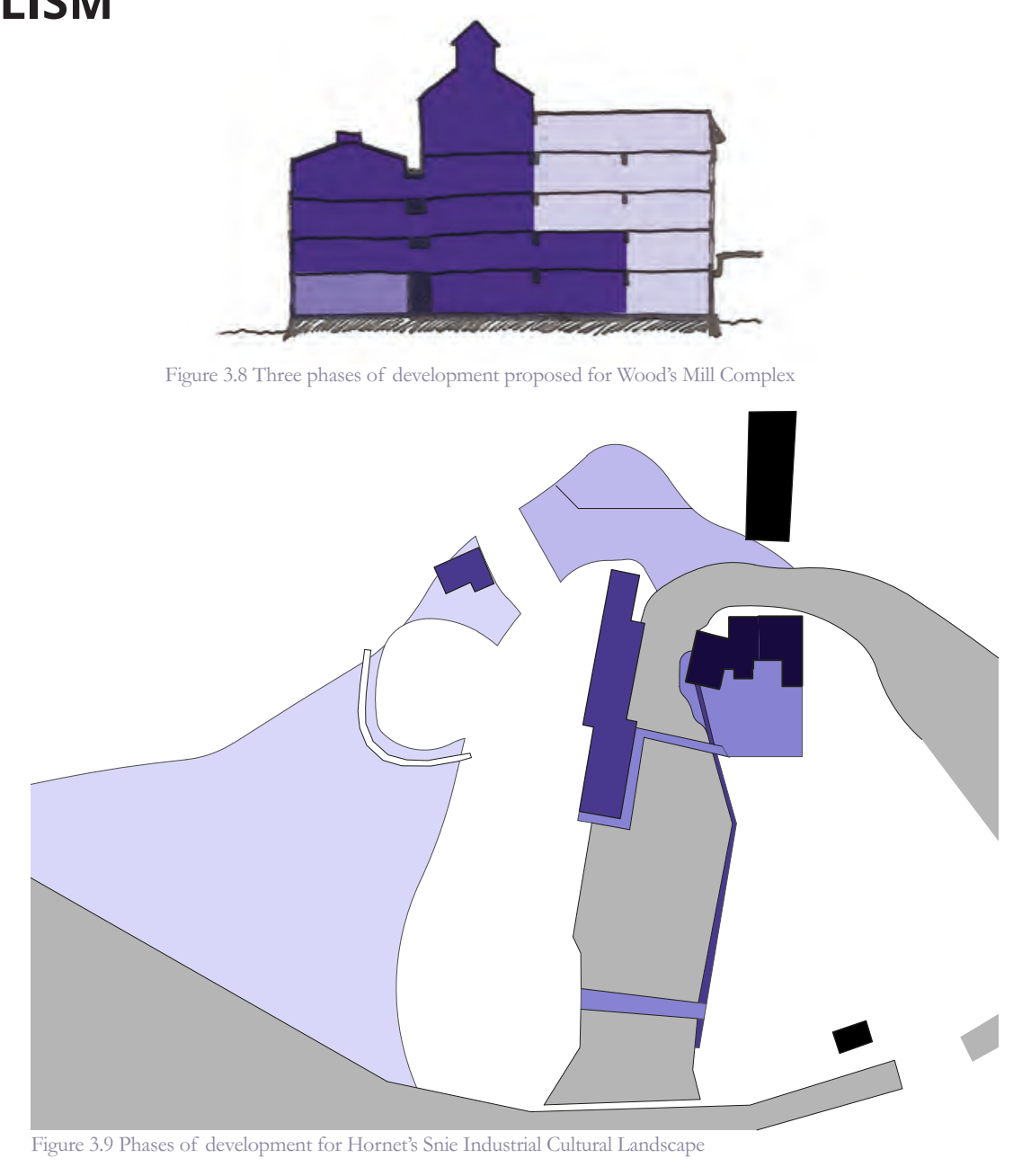




\section{Design Strategies: Minimal Intervention}

Minimal intervention is considered best practice in conservation because it poses the least risk to the heritage fabric and also often costs less. For this reason, it is important to maintain the historic load bearing masonry walls, wood frame and circulation cores (figure 3.10). All milling equipment on the third floor will remain in place. While renovating the West Mill basement for electricity generation, the extant milling equipment should be protected in place or temporarily removed and then reinstated. Although the façade of the granary will be replaced, the structure and roofing materials can be retained in situ. Additionally, the concrete mill dam will be repaired and converted into a pedestrian bridge.

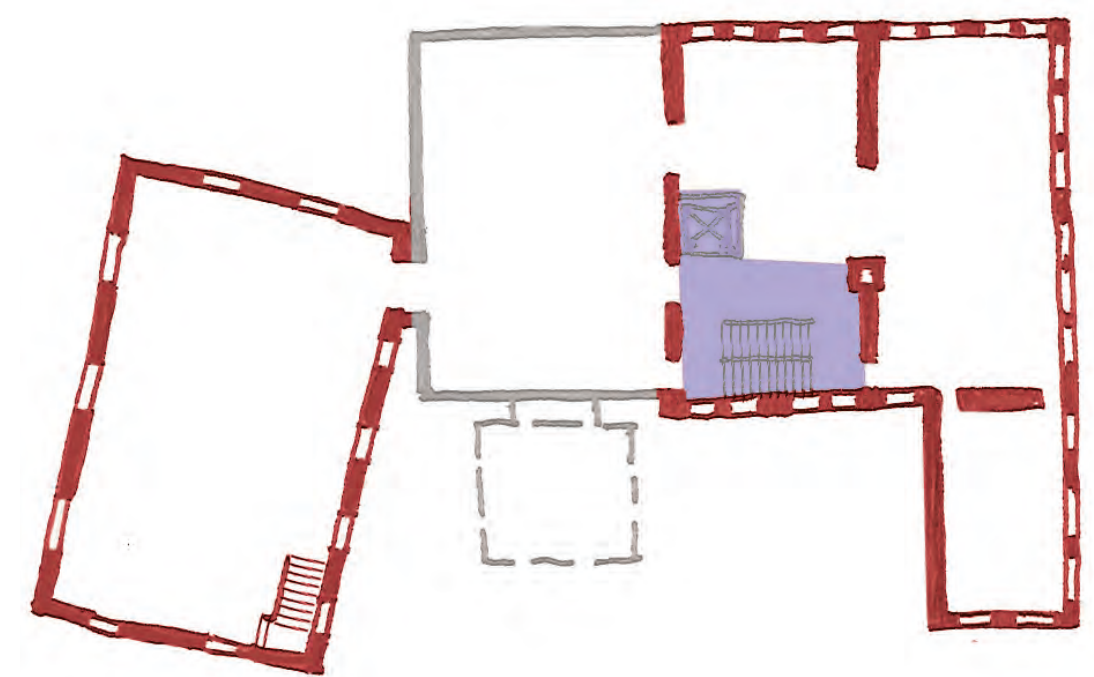




\section{Design Strategies: Locals and Visitors}

Since the ground floor is the most accessible it should be the most socially vibrant and welcoming for visitors. The museum is relocated to the ground floor and basement for this reason. Quieter working spaces and private offices are better suited for the top floors.

Residents of Smiths Falls, the surrounding areas and visitors were surveyed to determine their needs and desires for the site. Respondents are most interested in the following options: art gallery or studios; banquet and events facility; makerspace; community centre; and a microbrewery/restaurant. Additionally, there is a great need to support the youth and reduce youth homelessness, drug and alcohol use. The results of the survey are included in Appendix G.

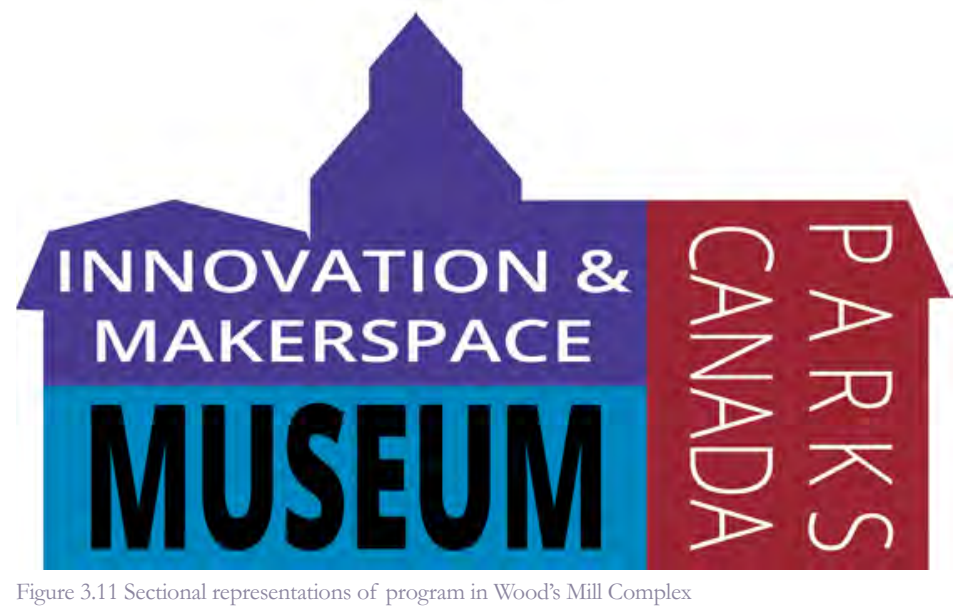

Projects with multiple uses have been shown to attract tourists and encourage residents to return often. ${ }^{1}$ Therefore, it is proposed to redevelop the mills to accommodate a variety of uses as shown in table 4. The proposed changes are shown in figures 3.3.11, 3.12 an 3.13.

1 Carol Berens, Redeveloping Industrial Sites: A Guide for Architects, Planners, and Developers (Hoboken, N.J: Wiley, 2010). 


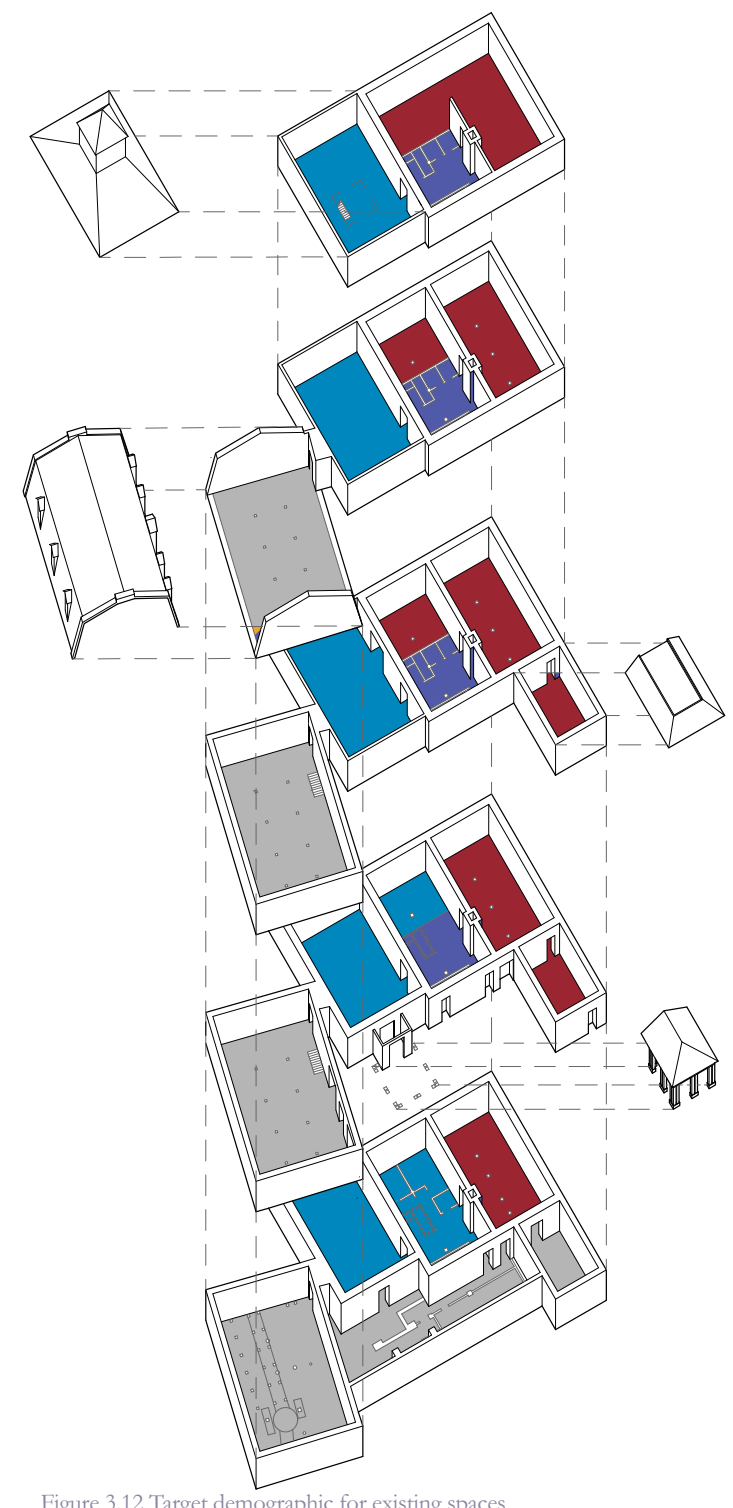

Building

Inhabitants

(Existing)

Mainly Locals

Mainly Visitors
Both Equally

Not Accessible

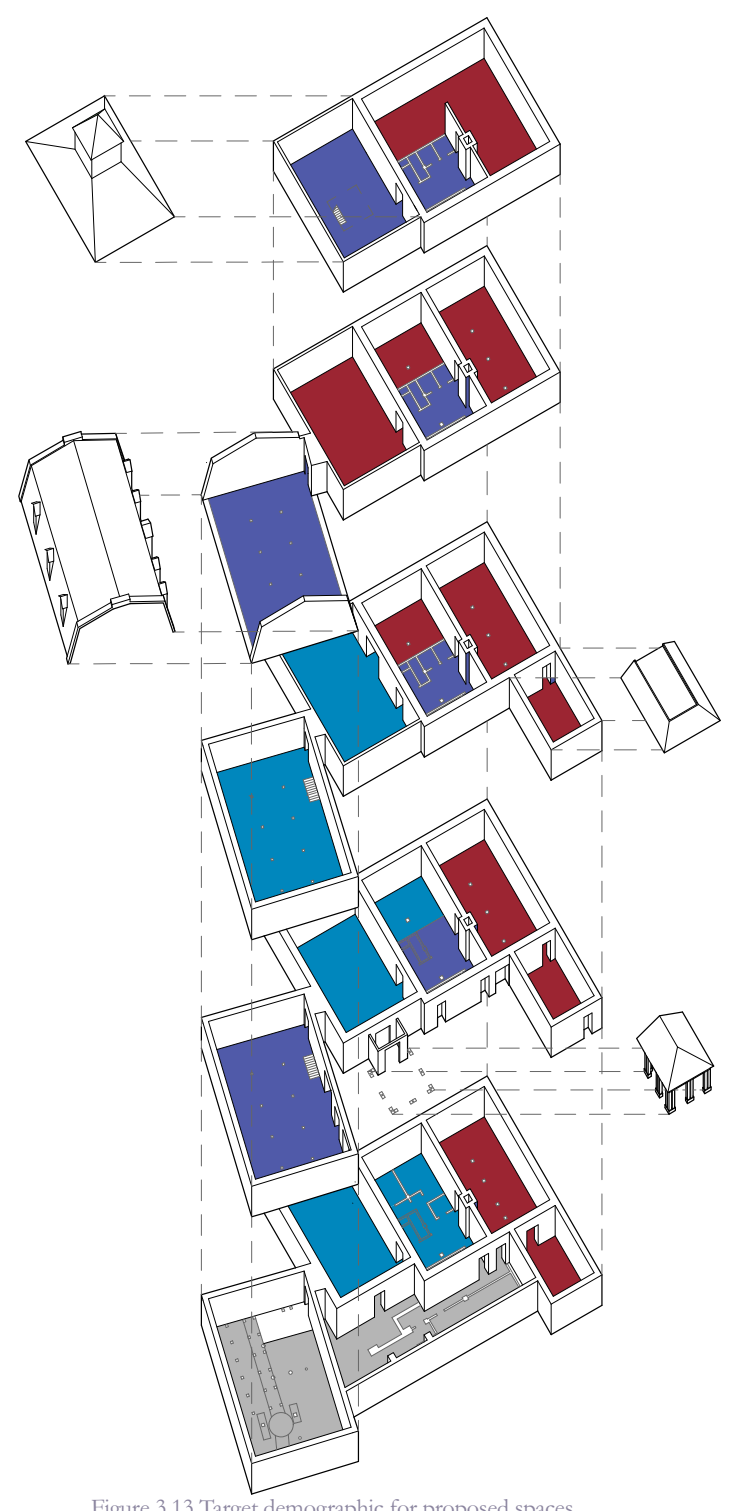

Figure 3.13 Target demographic for proposed spaces
Building

Inhabitants

(Proposed)

Mainly Locals

Mainly Visitors

Not accessible 
Table 4. Proposed programs for the Wood's Mill Complex

\begin{tabular}{|c|c|c|c|}
\hline$P R O G R A M$ & LOCATION & $\begin{array}{c}\text { TARGET } \\
\text { DEMOGRAPHIC }\end{array}$ & OVERLAP \\
\hline Art gallery and shop & West Mill, ground floor & visitors & Locals can exhibit and sell their work \\
\hline $\begin{array}{l}\text { Canoe- and snowshoe- } \\
\text { building workshop }\end{array}$ & West Mill, ground floor & visitors & Hands-on museum exhibit run by local craftspeople; locals can also participate \\
\hline Museum exhibits & $\begin{array}{l}\text { West Mill and granary, } \\
\text { ground floor and basement }\end{array}$ & visitors & Museum can be a "client" for local makers and entrepreneurs \\
\hline $\begin{array}{l}\text { Hydroelectric power } \\
\text { station }\end{array}$ & West Mill, basement & locals & Viewing area where visitors can see how electricity is generated \\
\hline Parks Canada Offices & East Mill, all floors & locals & $\mathrm{n} / \mathrm{a}$ \\
\hline $\begin{array}{l}\text { Banquet and events } \\
\text { facility }\end{array}$ & $\begin{array}{l}\text { West Mill and granary, } \\
\text { second floor }\end{array}$ & locals and visitors & Depends on the event \\
\hline Private offices & West Mill, third floor & locals & $\mathrm{n} / \mathrm{a}$ \\
\hline Co-working spaces & West Mill, third floor & locals & $\begin{array}{l}\text { Great for freelance workers and visitors working on short-term projects in the } \\
\text { area }\end{array}$ \\
\hline $\begin{array}{l}\text { Makerspace, workshop } \\
\text { and assembly area }\end{array}$ & Granary, third floor & locals & $\begin{array}{l}\text { Great for freelance workers and visitors working on short-term projects in the } \\
\text { area }\end{array}$ \\
\hline $\begin{array}{l}\text { Digital fabrication } \\
\text { laboratory }\end{array}$ & Granary, third floor & locals & Visitors can come to town to use specialized equipment \\
\hline $\begin{array}{l}\text { Computer and } \\
\text { technology laboratory }\end{array}$ & Granary, fourth floor & locals & $\begin{array}{l}\text { Great for freelance work and visitors working on short-term projects in the } \\
\text { area }\end{array}$ \\
\hline $\begin{array}{l}\text { Virtual Simulation } \\
\text { room }\end{array}$ & Granary, fourth floor & visitors & Locals can design content for this part of the museum \\
\hline
\end{tabular}




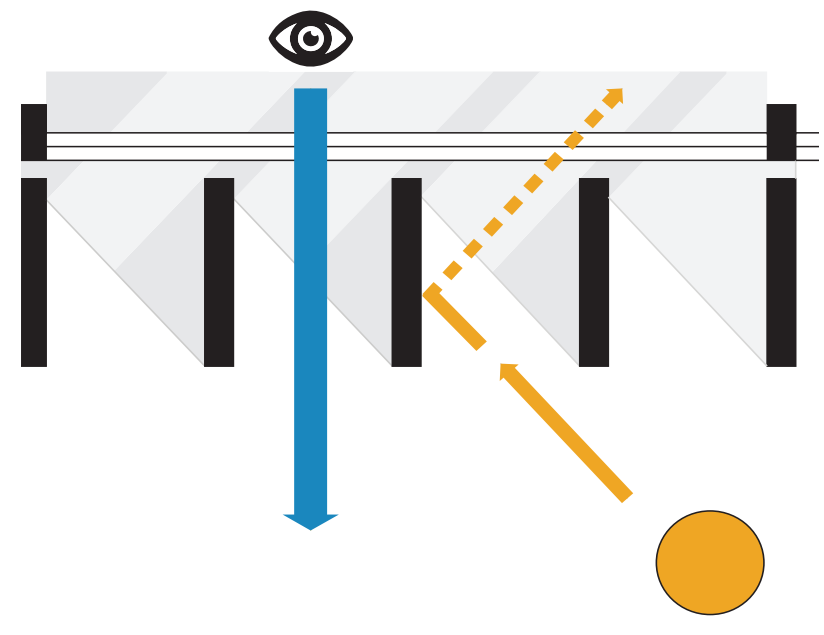

The corrugated metal façade of the reconstructed granary maintains its historic monolithic appearance but fails to take advantage of the spectacular views of its surroundings or allow natural light to the building interior. The proposed façade consists of a transparent curtain wall with vertical wood louvers on the exterior to maintain a solid monolithic appearance during the day while still allowing views out. The louvers on the south façade are programmed to rotate according to the position of the sun (figure 3.14). In addition to minimizing heating and cooling costs, the louvers frame different views of the industrial cultural landscape throughout the day. The north and west facades have fixed louvers since there is not a significant solar benefit to justify the added cost of operable louvers. The louvers also reduce glare and unwanted solar heat gain in the summer and improving passive solar heating in the winter. At night, people can catch glimpses of the activity going on inside the building and lighting can give the granary the appearance of a waterfall.

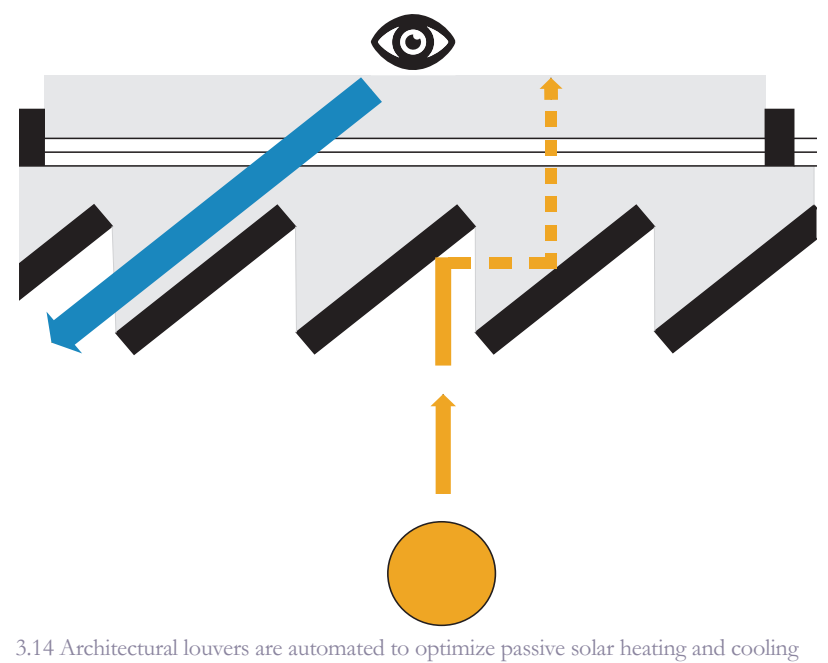




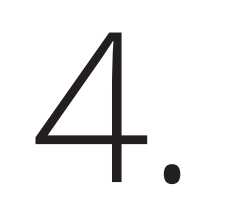

INTERVENE \& MAINTAIN 


\section{Conservation Treatments}

The primary conservation treatment for the Hornet's Snie Industrial Cultural Landscape is rehabilitation. This includes: adding infrastructure to transport water to the West Mill to generate electricity; adapting the mill dam to become a pedestrian bridge; installing rain gardens; installing a path behind the Water Works Building; daylighting the original path of the river; and planting flowers to interpret the of the site. Other treatments include restoration of the Canal Street Bridge and preservation of trees, parkland and parking lots. The bird's eye view (figure 4.2), site plan (figure 4.3) and site section (figure 4.4) illustrate the proposed changes to the landscape.

Rehabilitation is also the primary treatment of the Wood's Mill Complex as illustrated in figure 4.1. Major alterations include: replacing the granary façade; a new entrance vestibule; and refitting the basement for hydroelectric power. Other minor rehabilitation treatments include: levelling the West Mill floors, improving airtightness and insulation of the roofs and exterior masonry walls. The proposed changes are shown in elevation (figure 4.5), plans (figures 4.6 through 4.10), vignettes (figures 4.11 through 4.16) and model (figures .

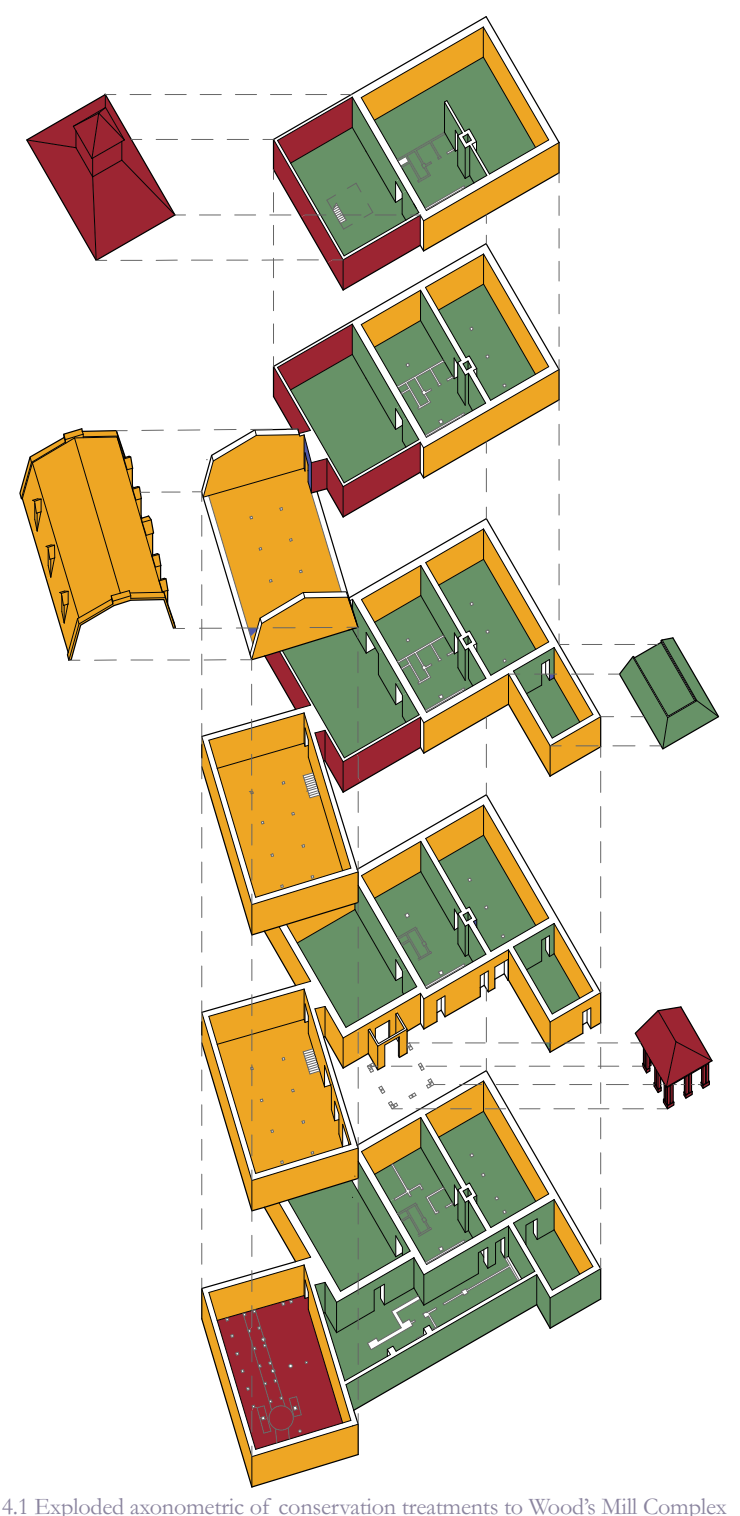

Conservation

Treatments

Preservation

Rehabilitation (Minimal) Rehabilitation (Extensive) 


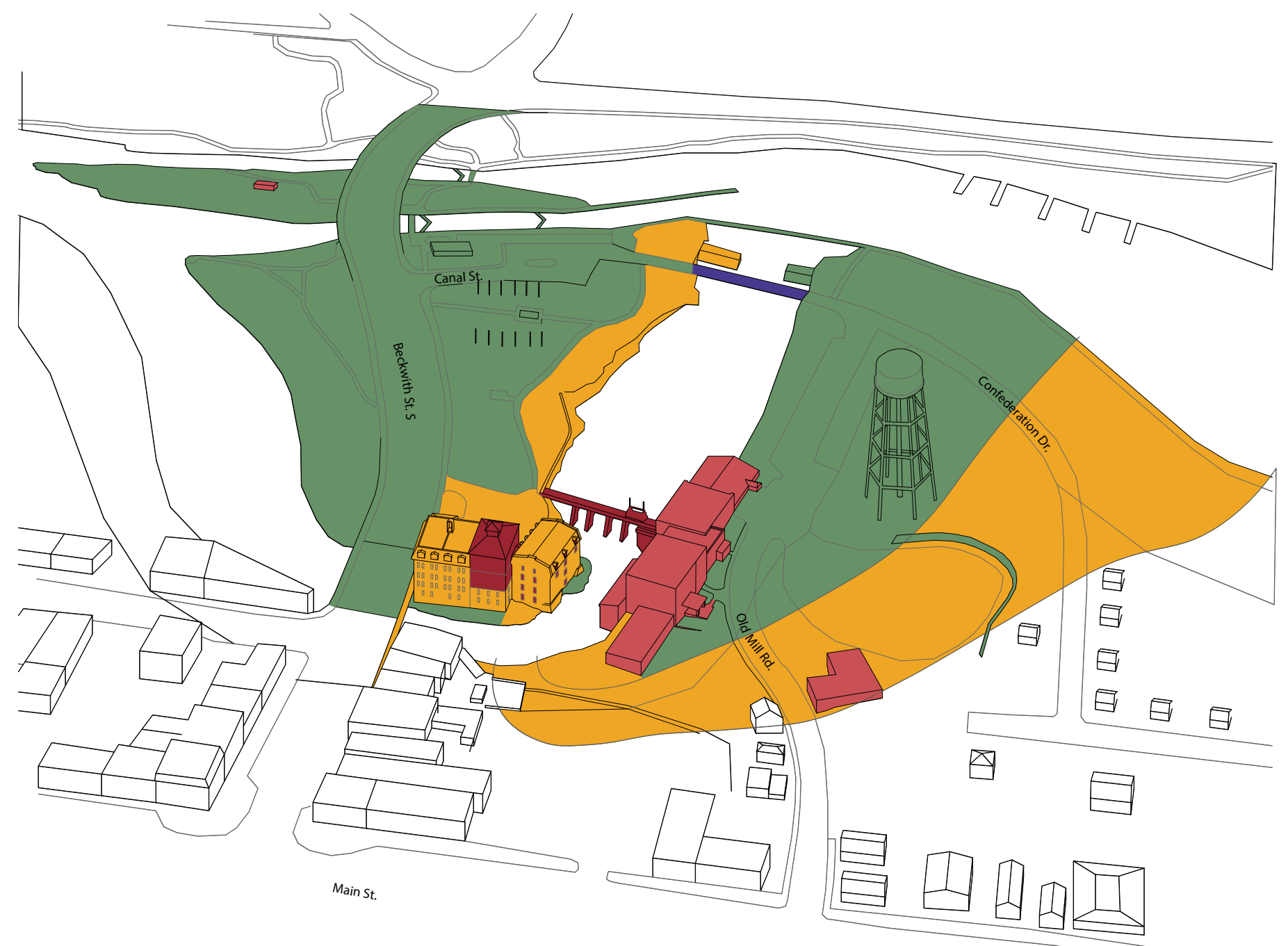

Preservation

Minor Rehabilitation

Major Rehabilitation (Phase 1)

Major Rehabilitation (later phase) 


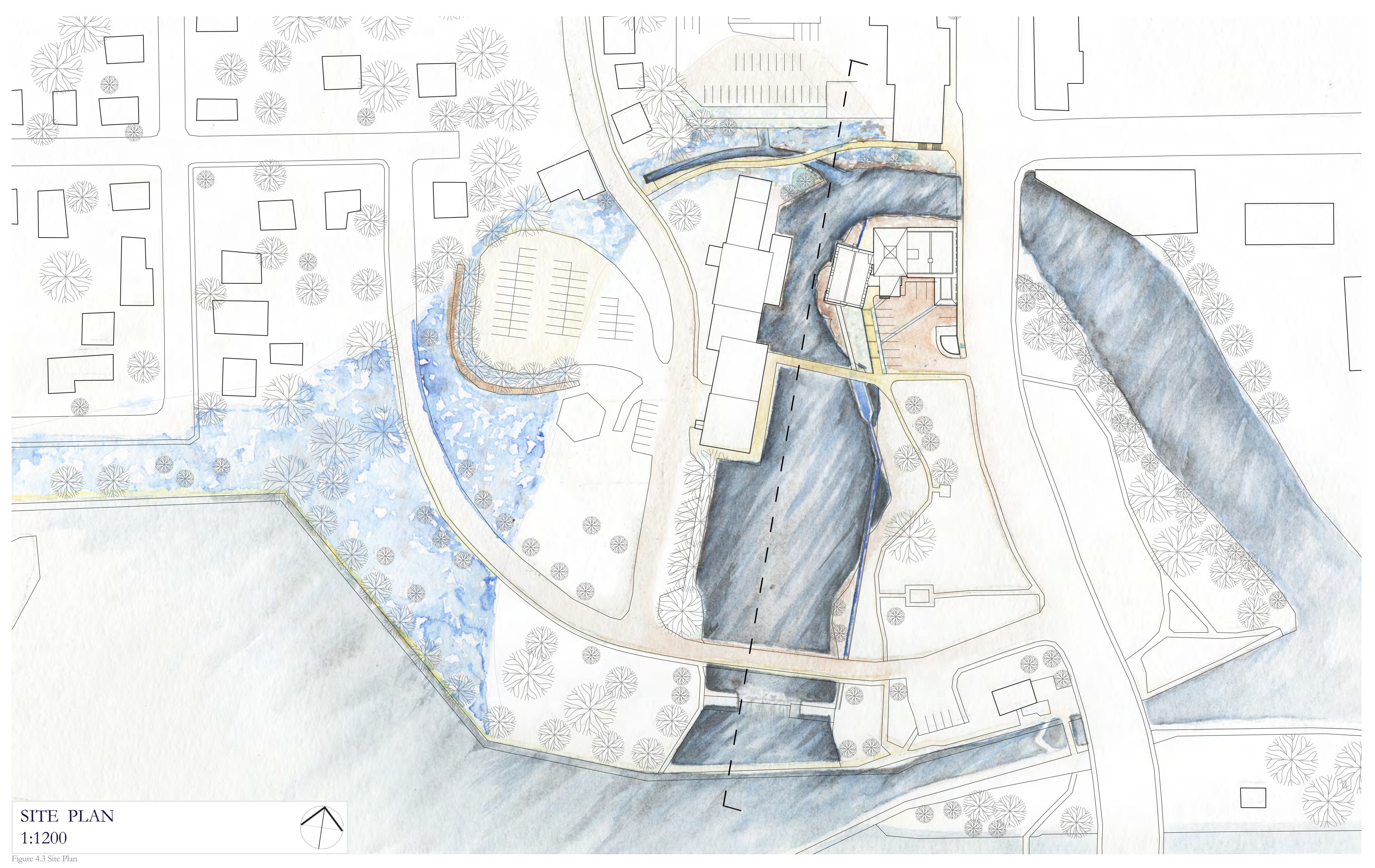




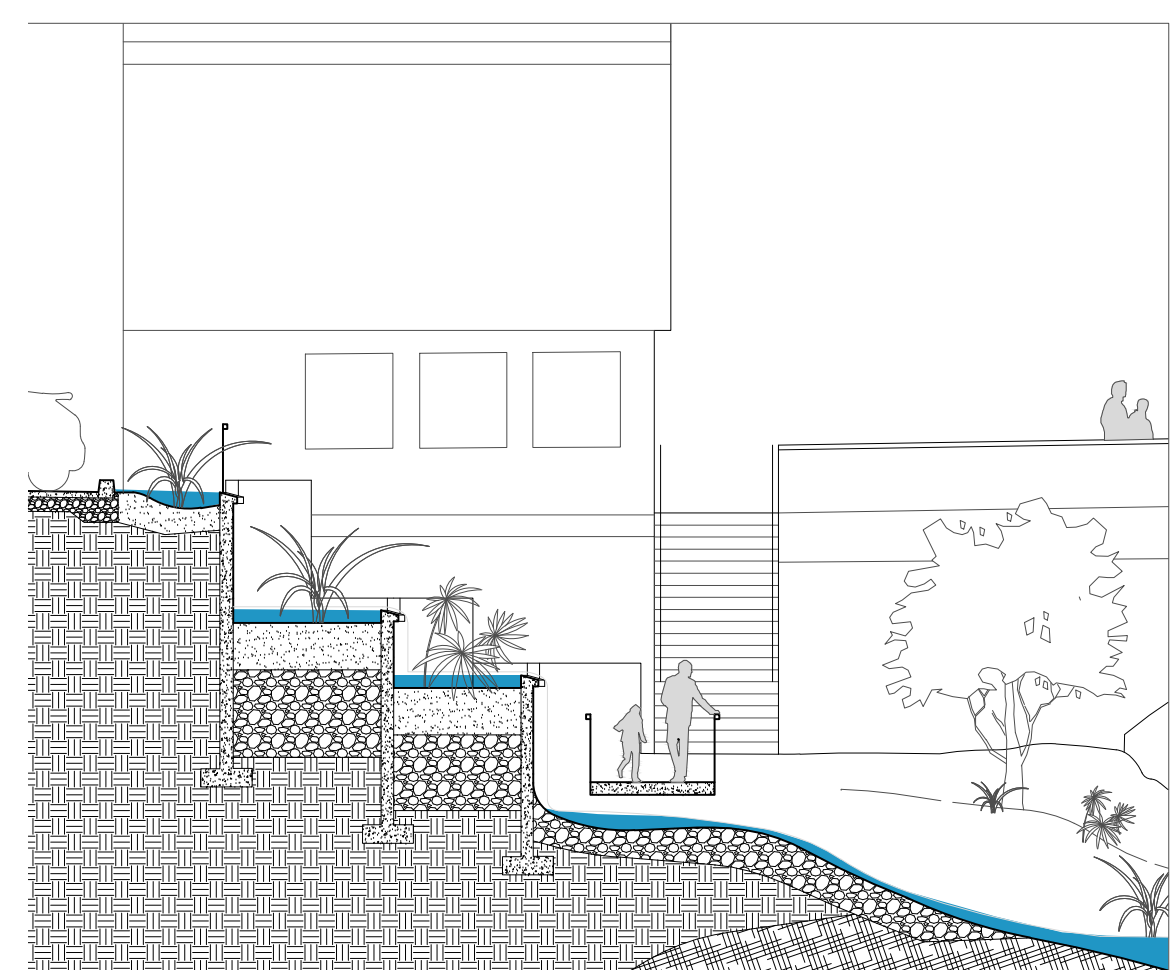

SITE SECTION

$1: 150$

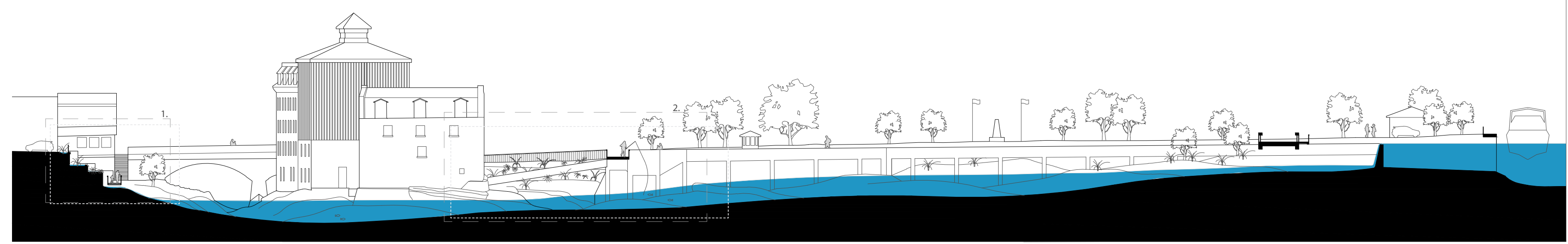

SITE SECTION

1:600

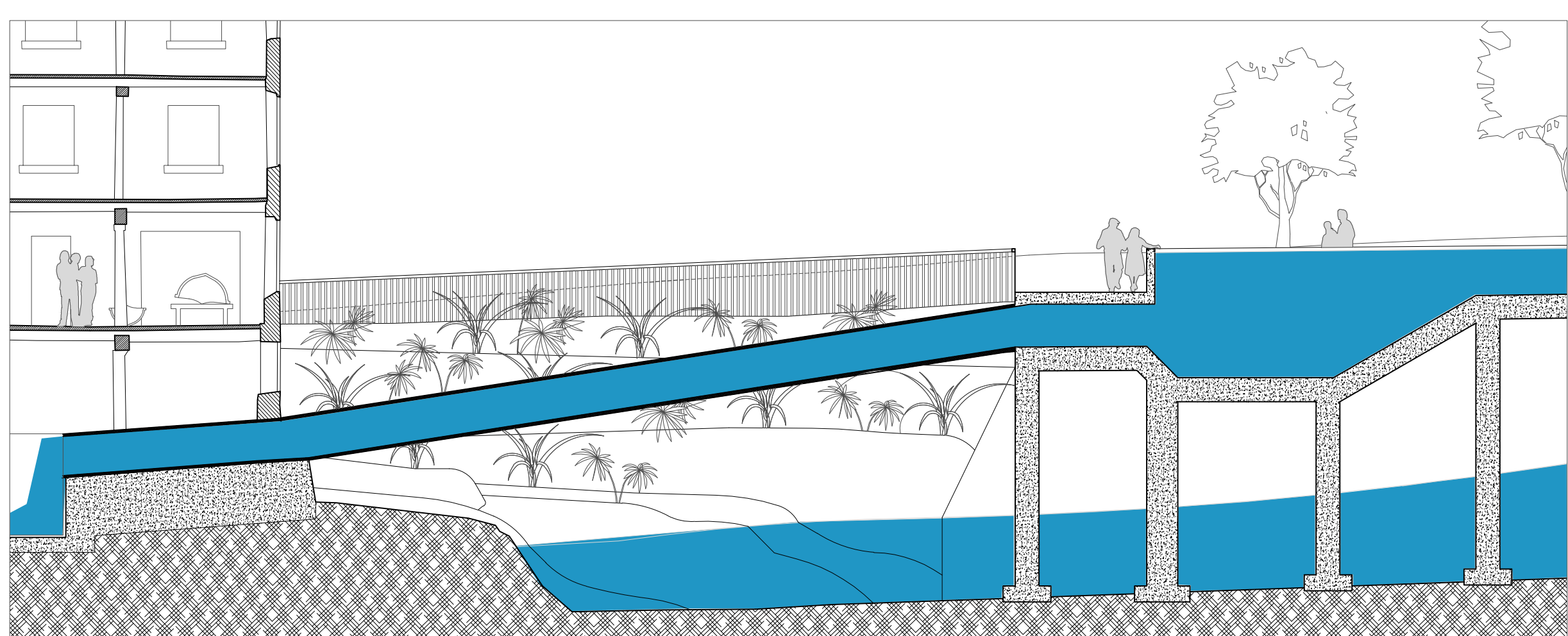

SITE SECTION

1:150 

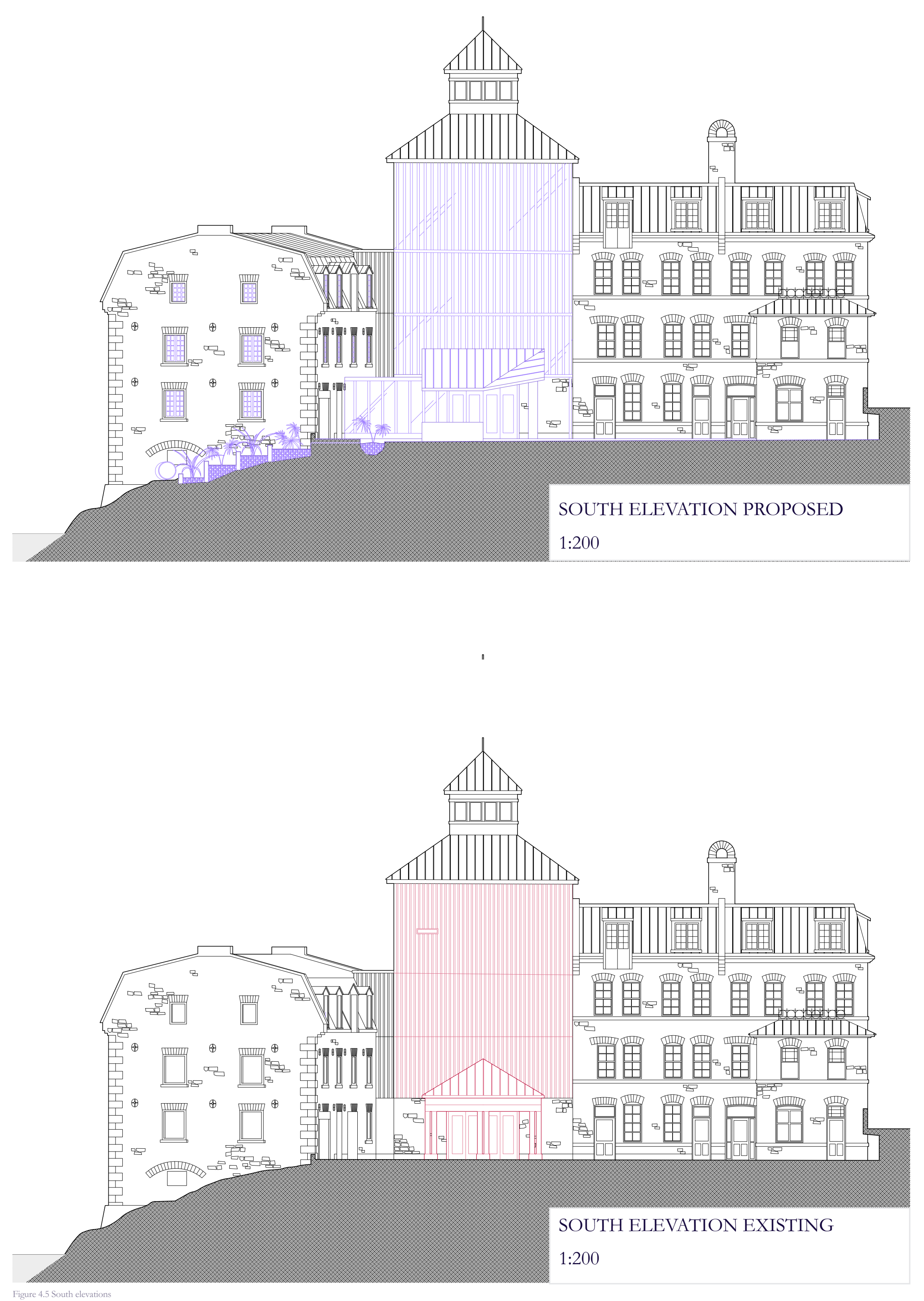


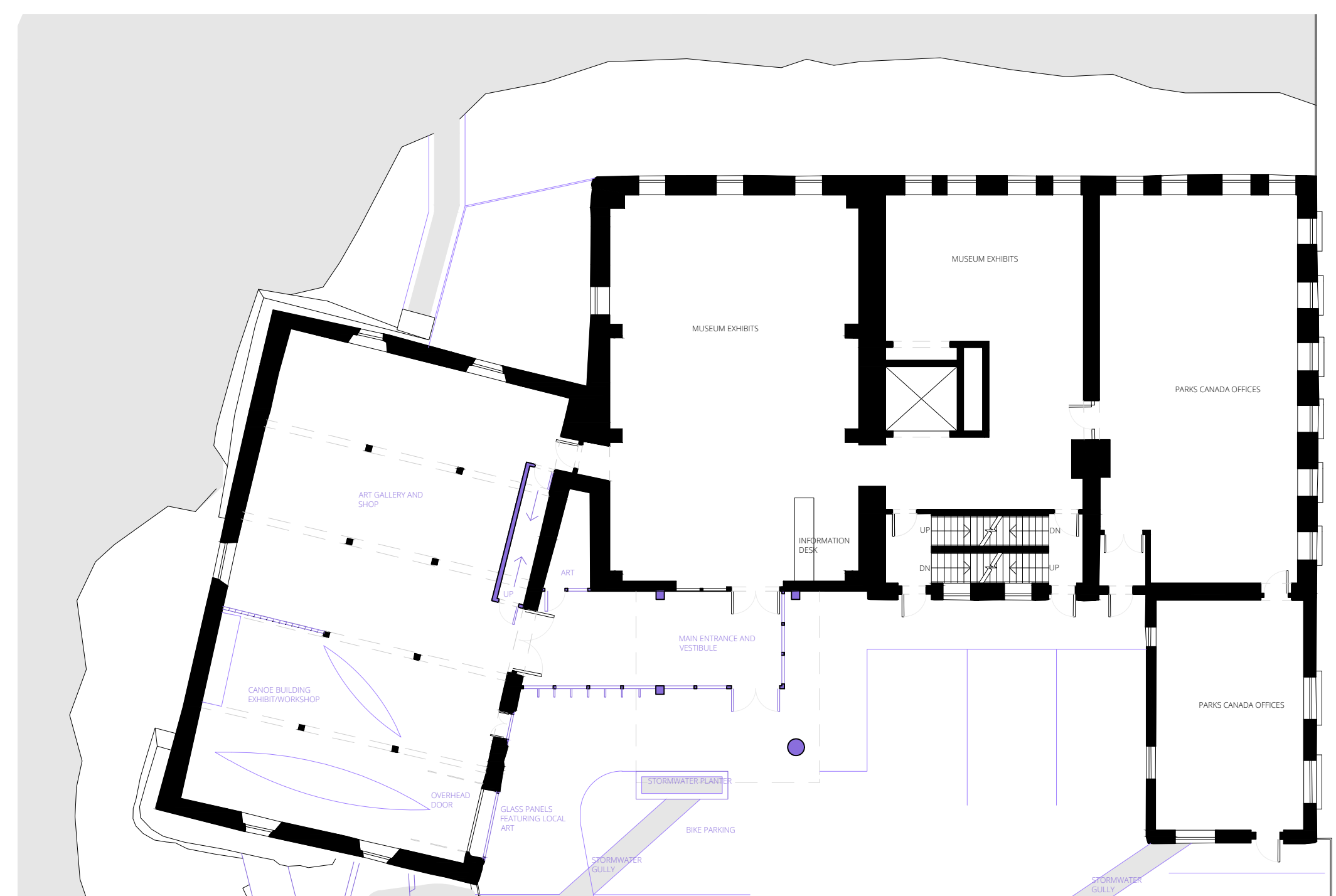

GROUND FLOOR PROPOSED 1:200

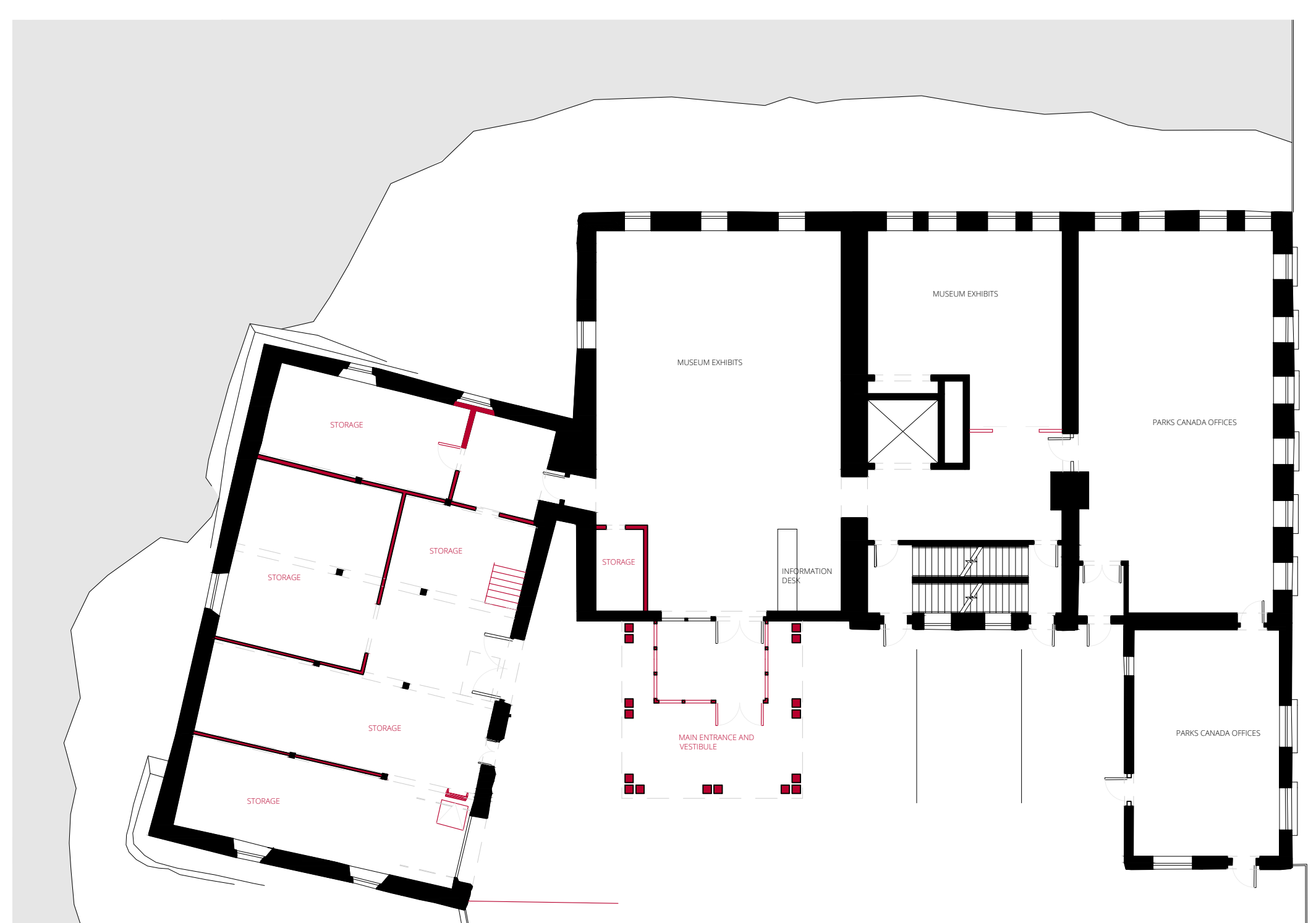

GROUND FLOOR EXISTING 1:200 

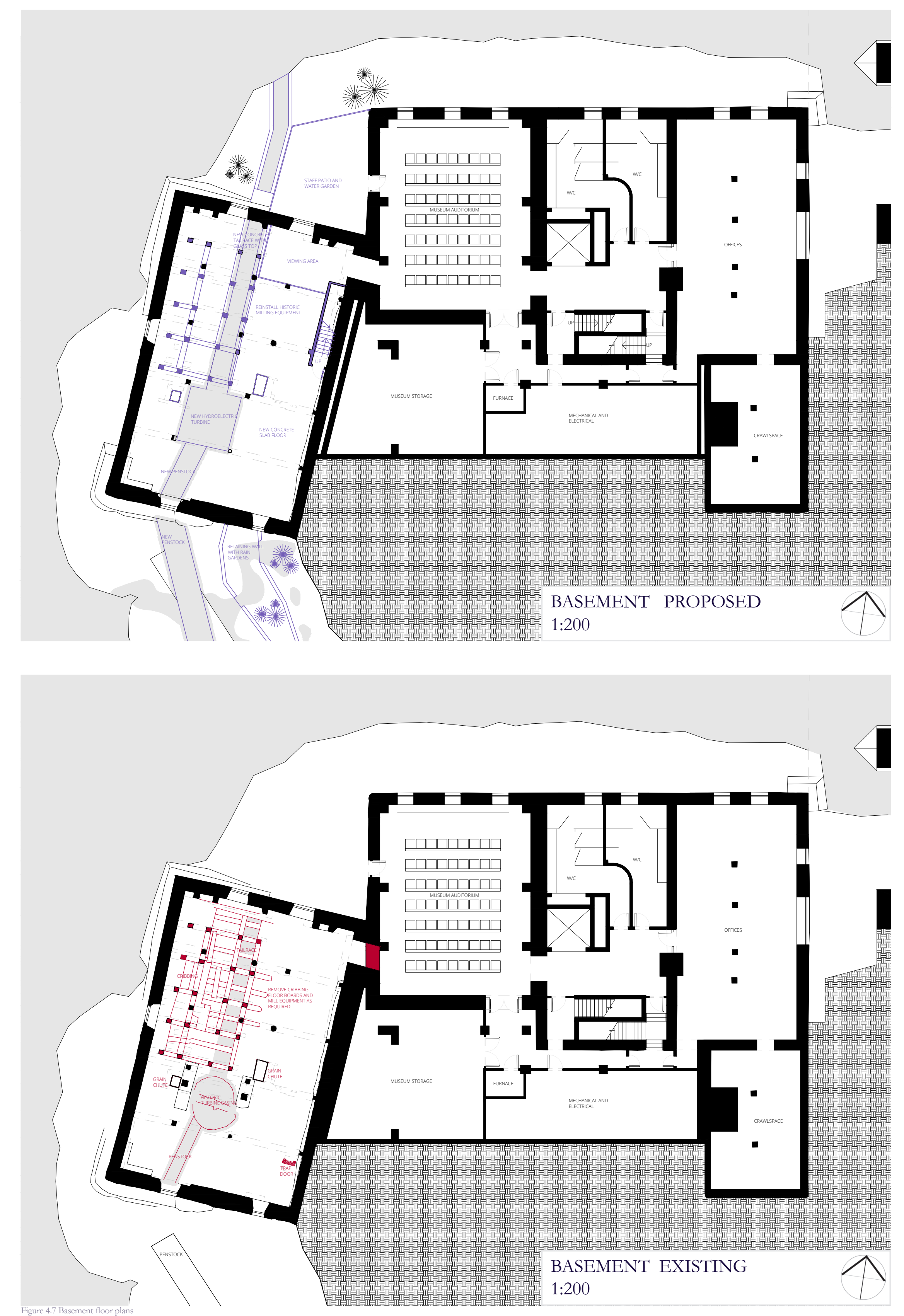

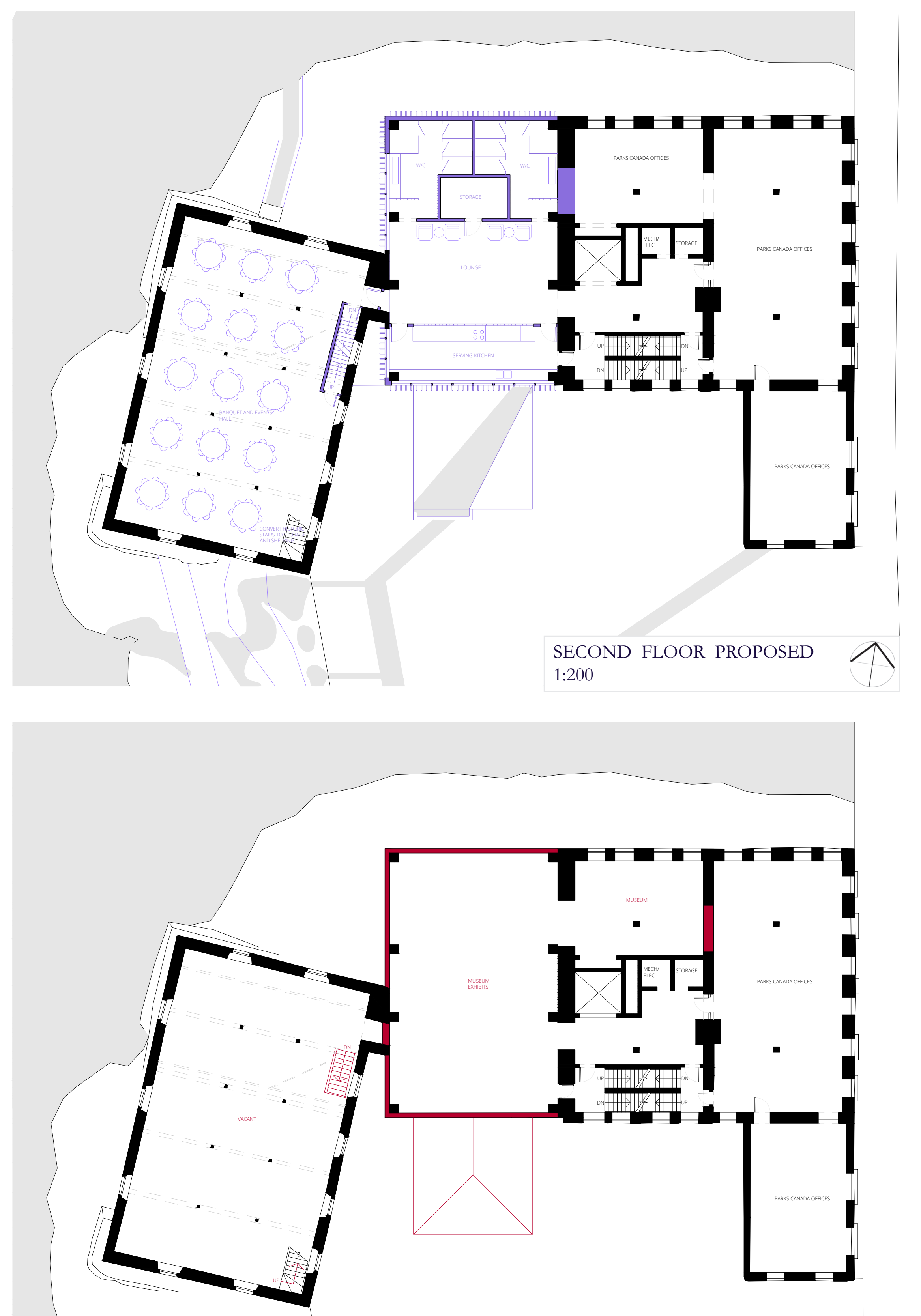

SECOND FLOOR EXISTING 1:200 

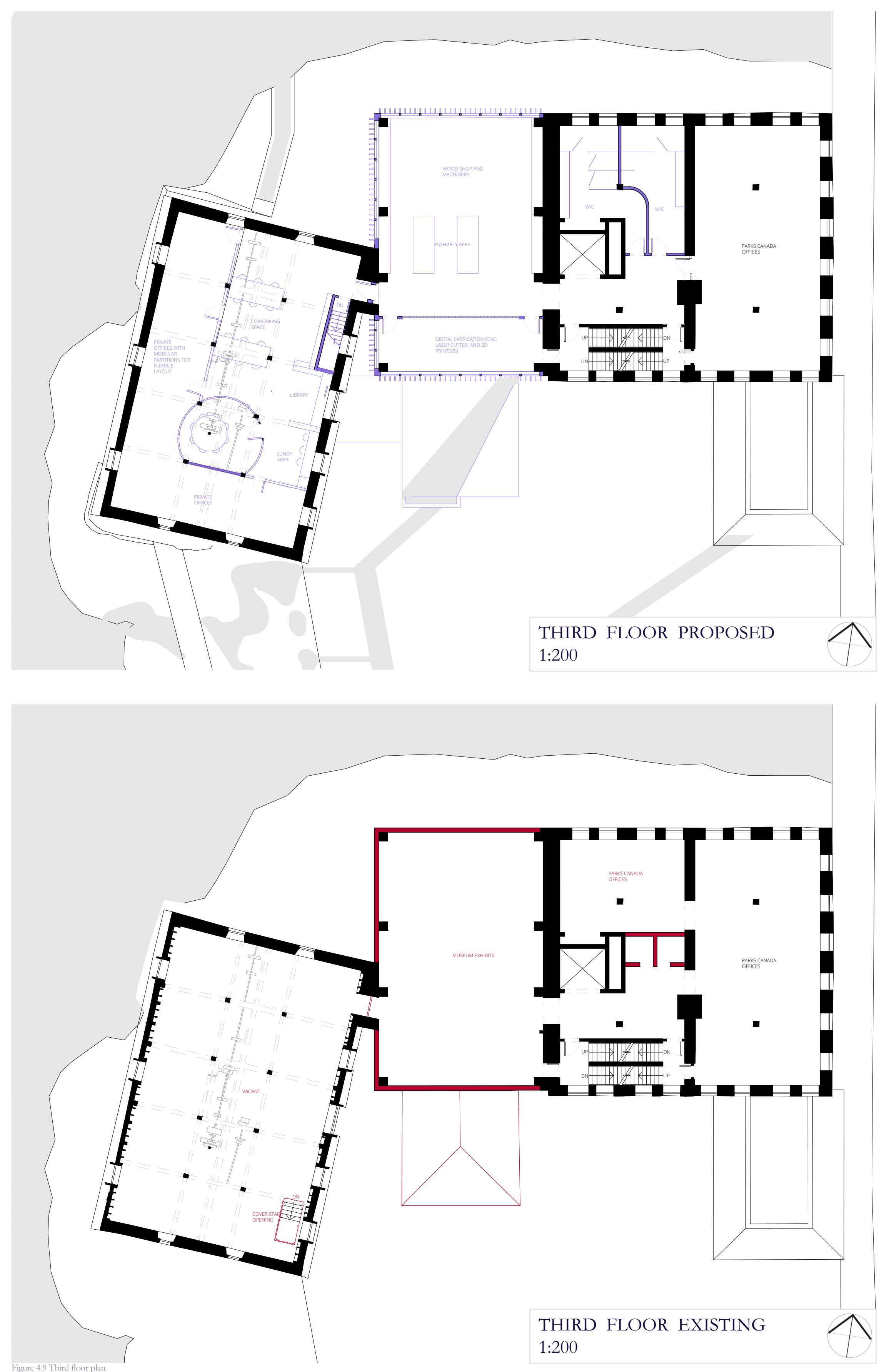


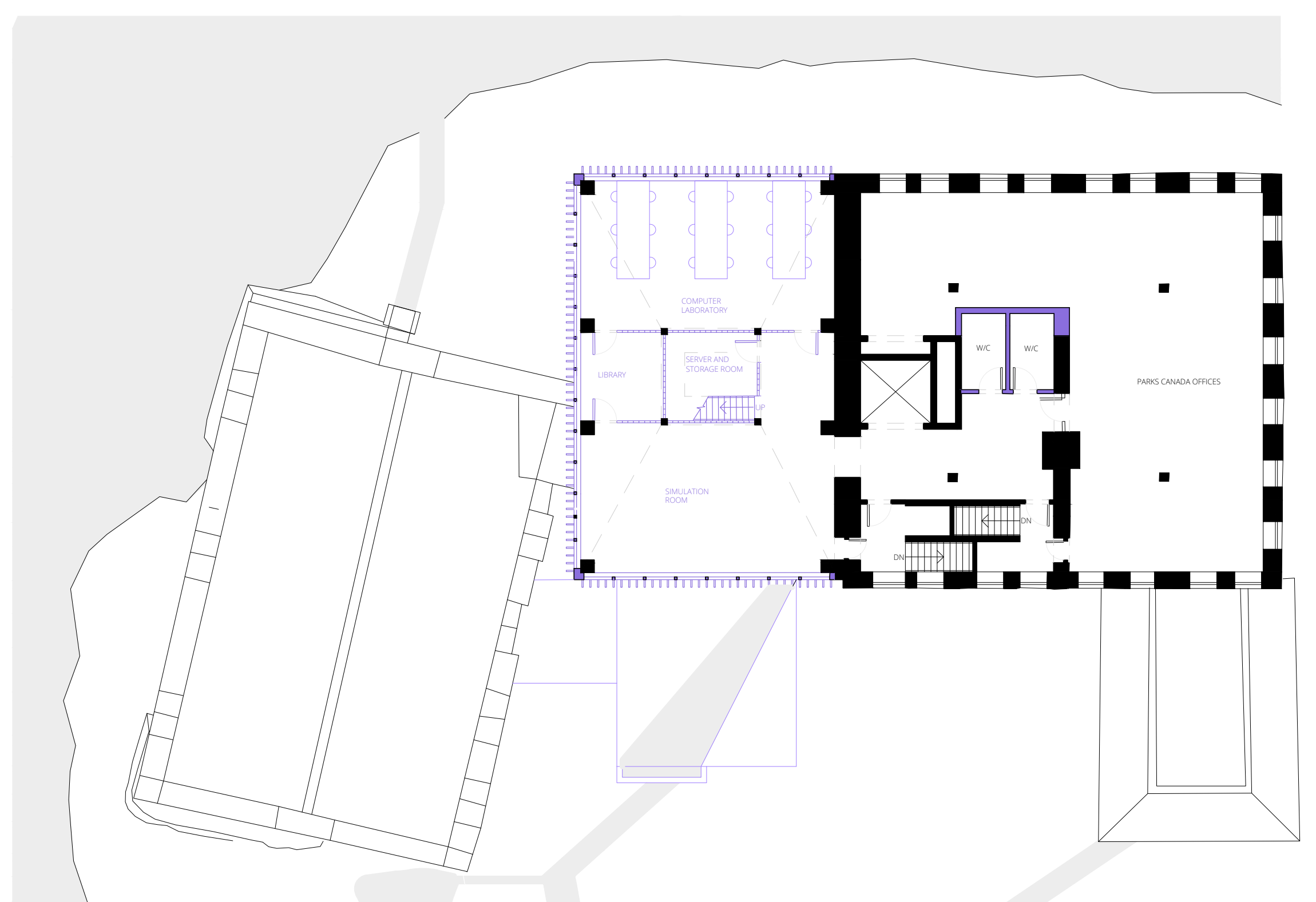

FOURTH FLOOR PROPOSED 1:200
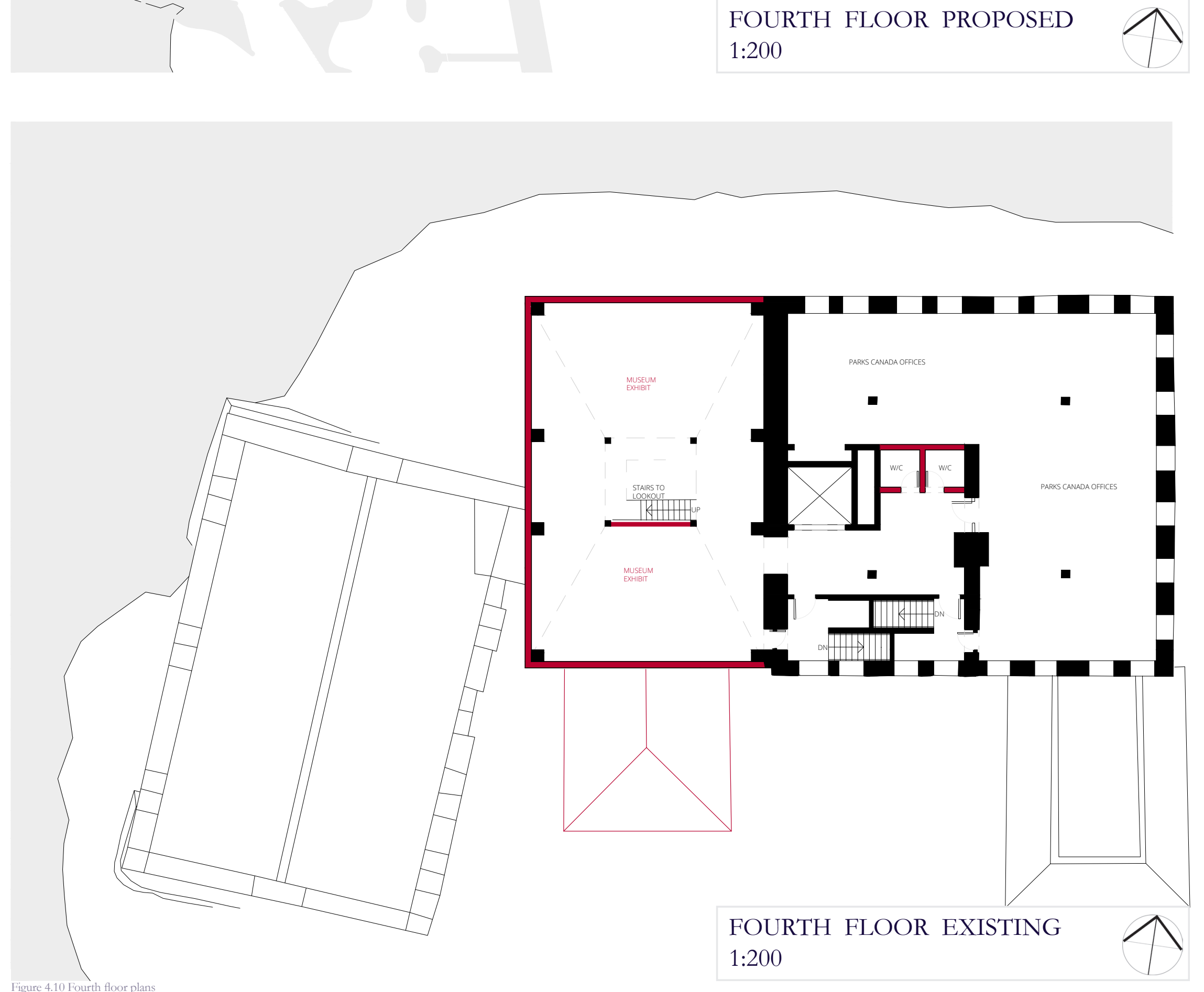


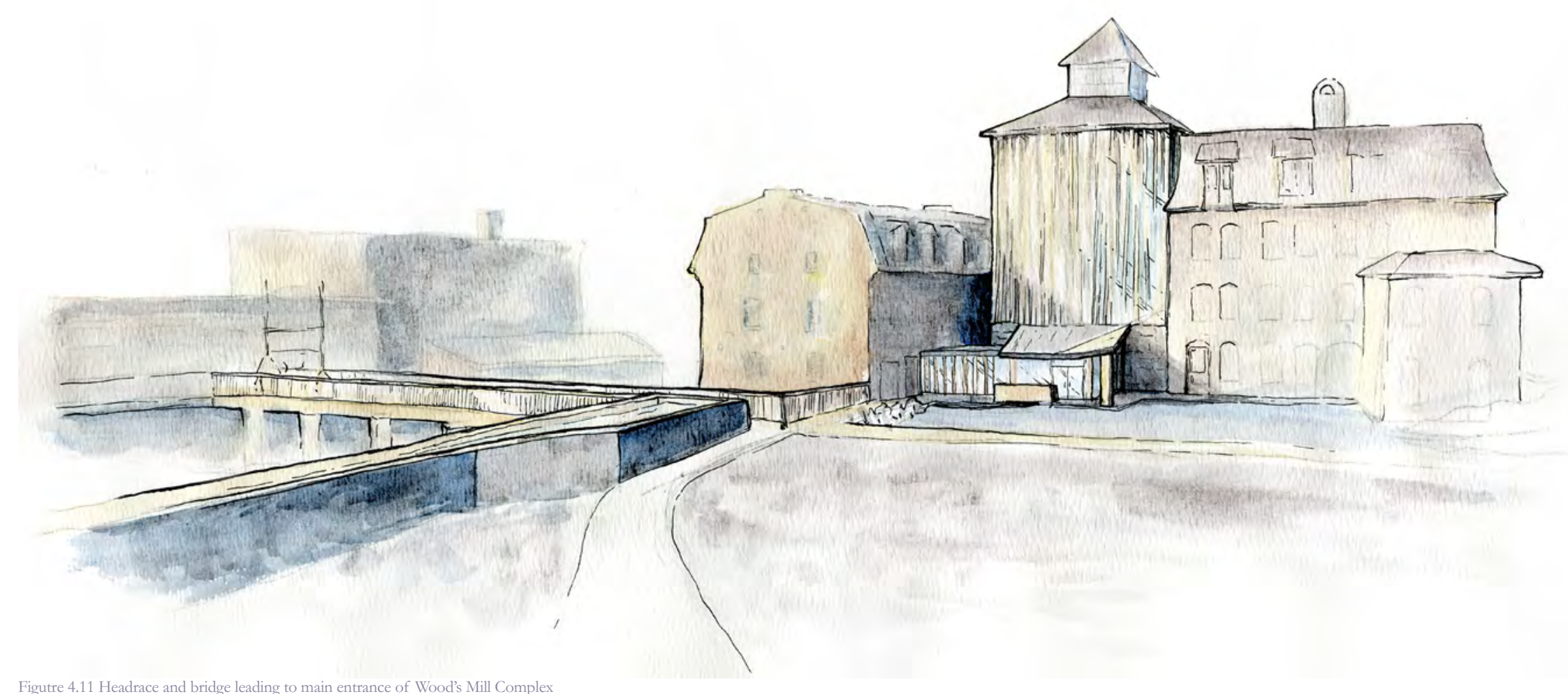



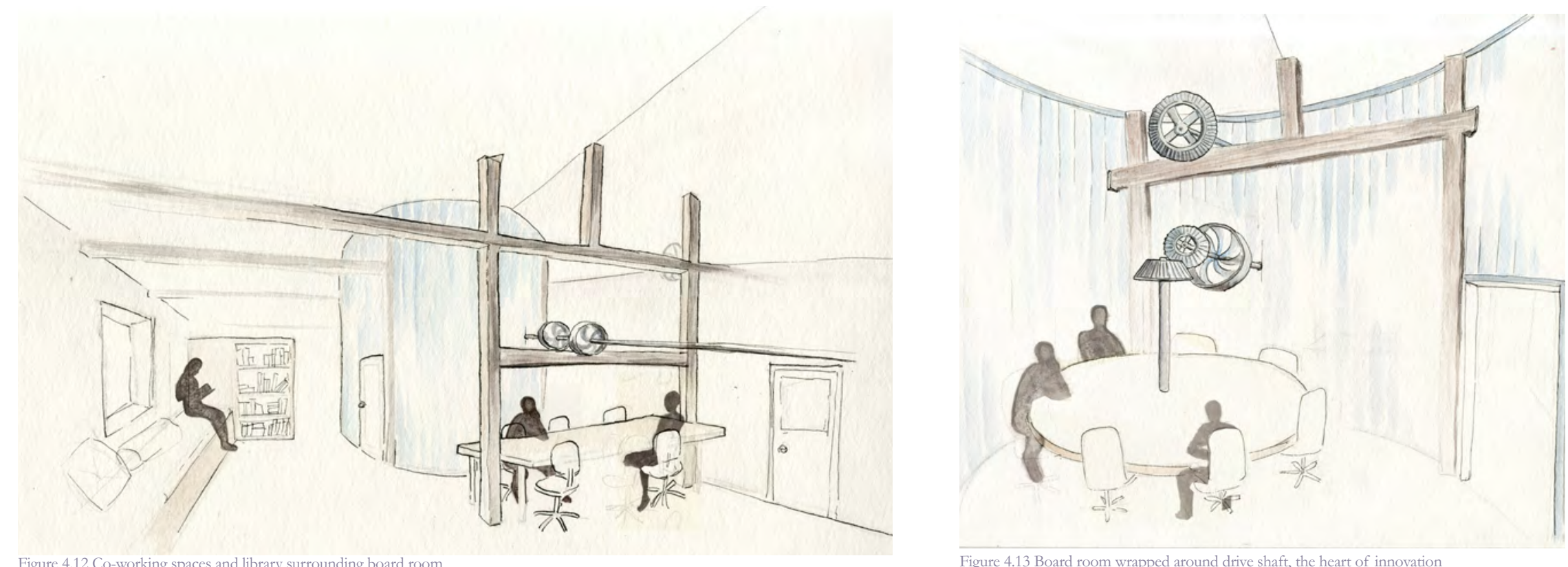


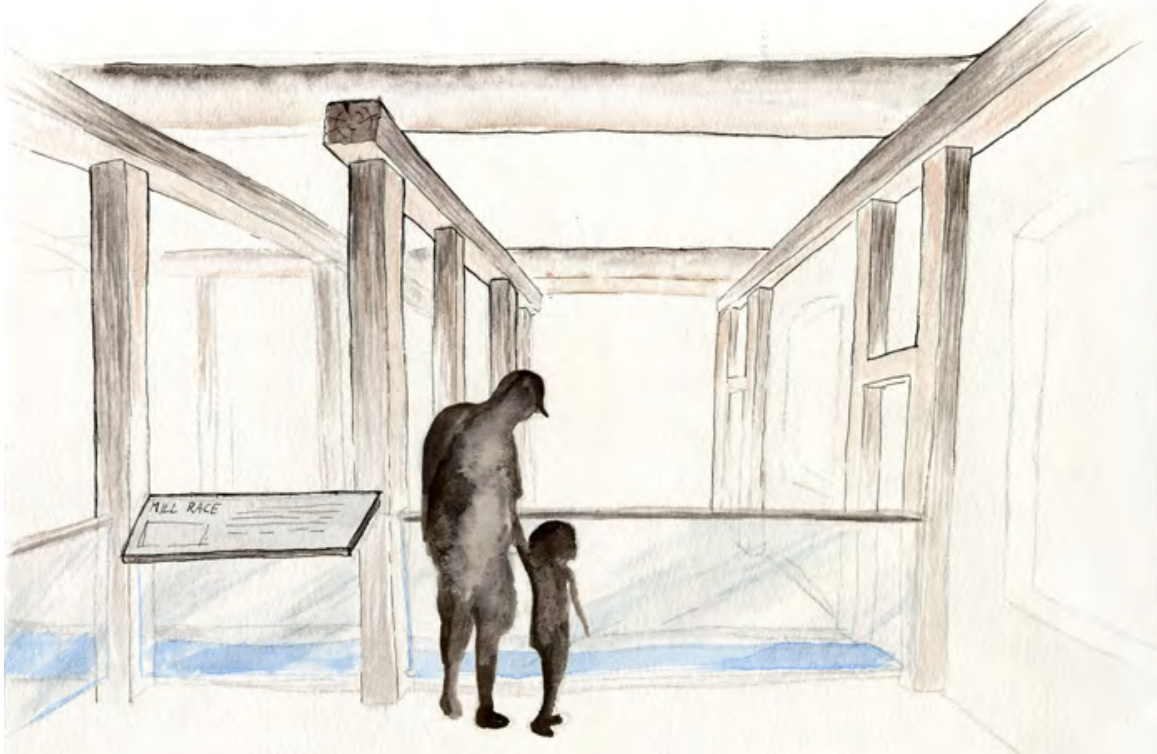

Figure 4.14 Interpretive area of West Mill basement with views to water exitng the tailrace

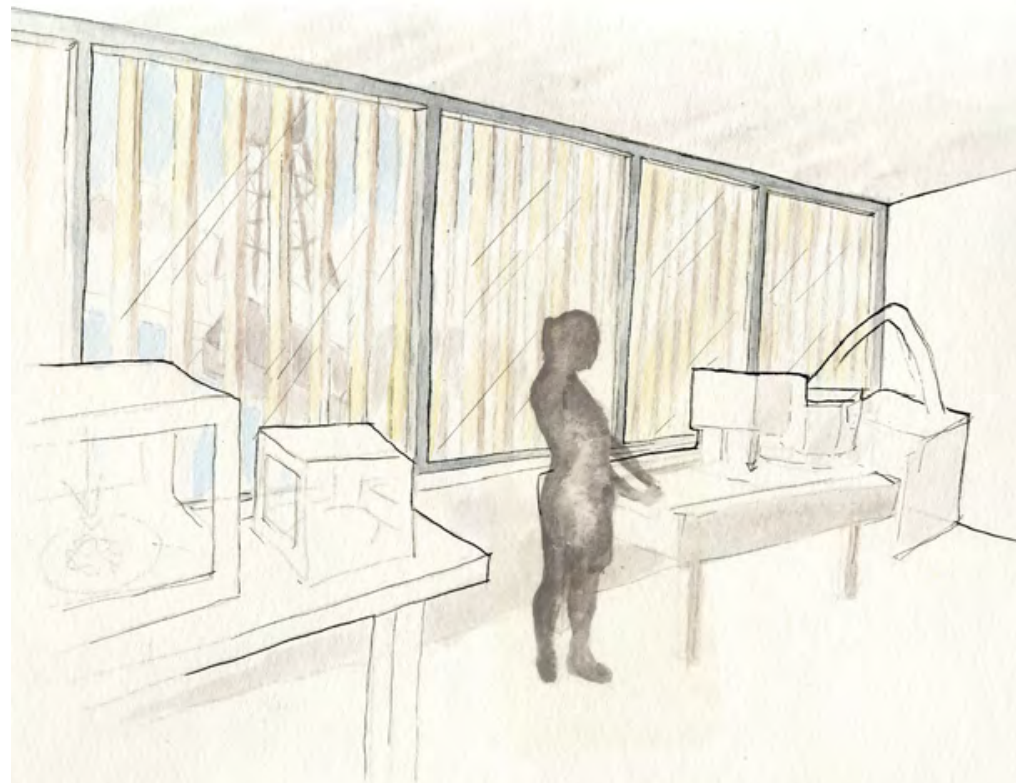

Figure 4.15 Digital fabrication lab with views to Water Works Building 

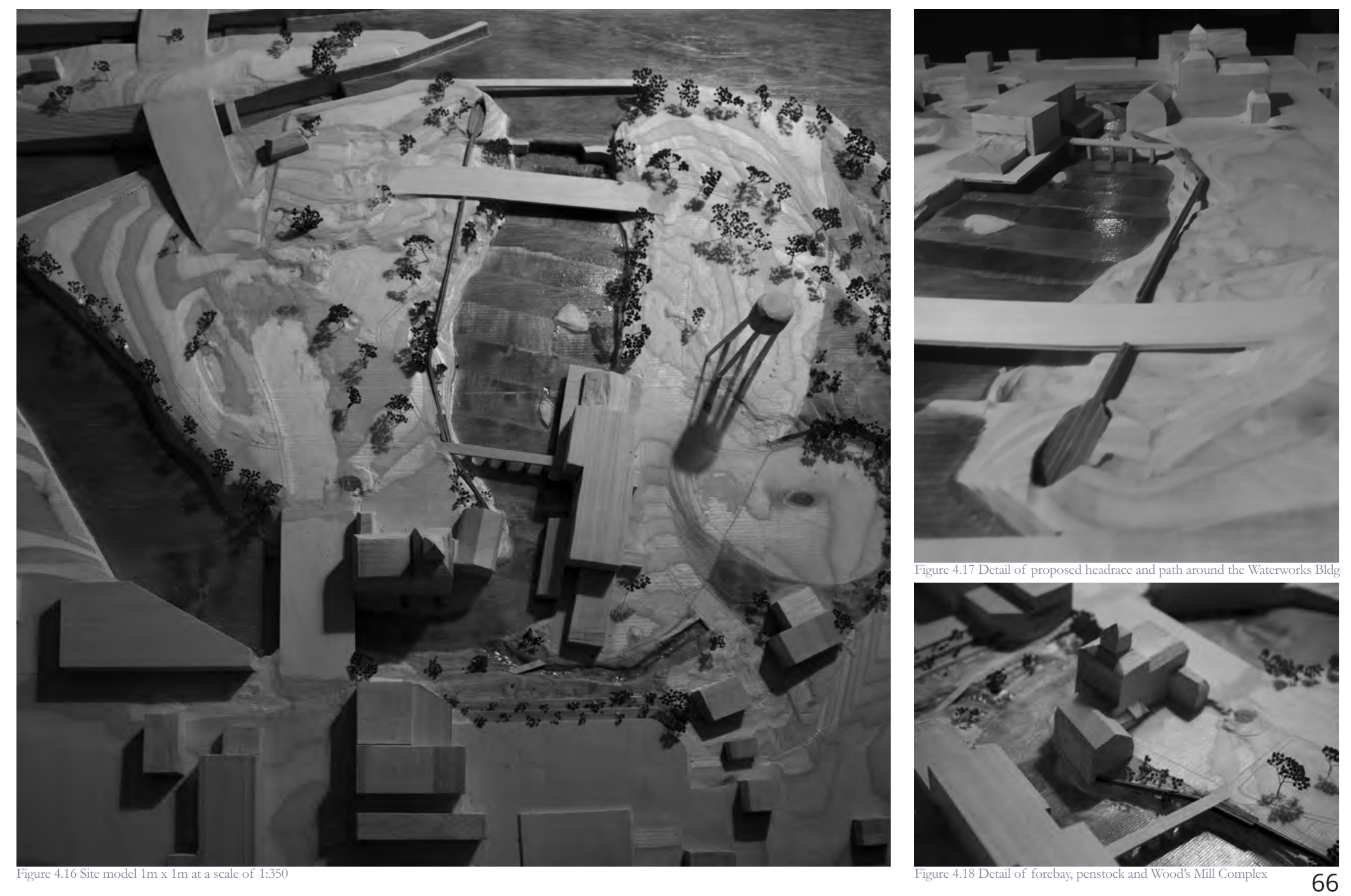

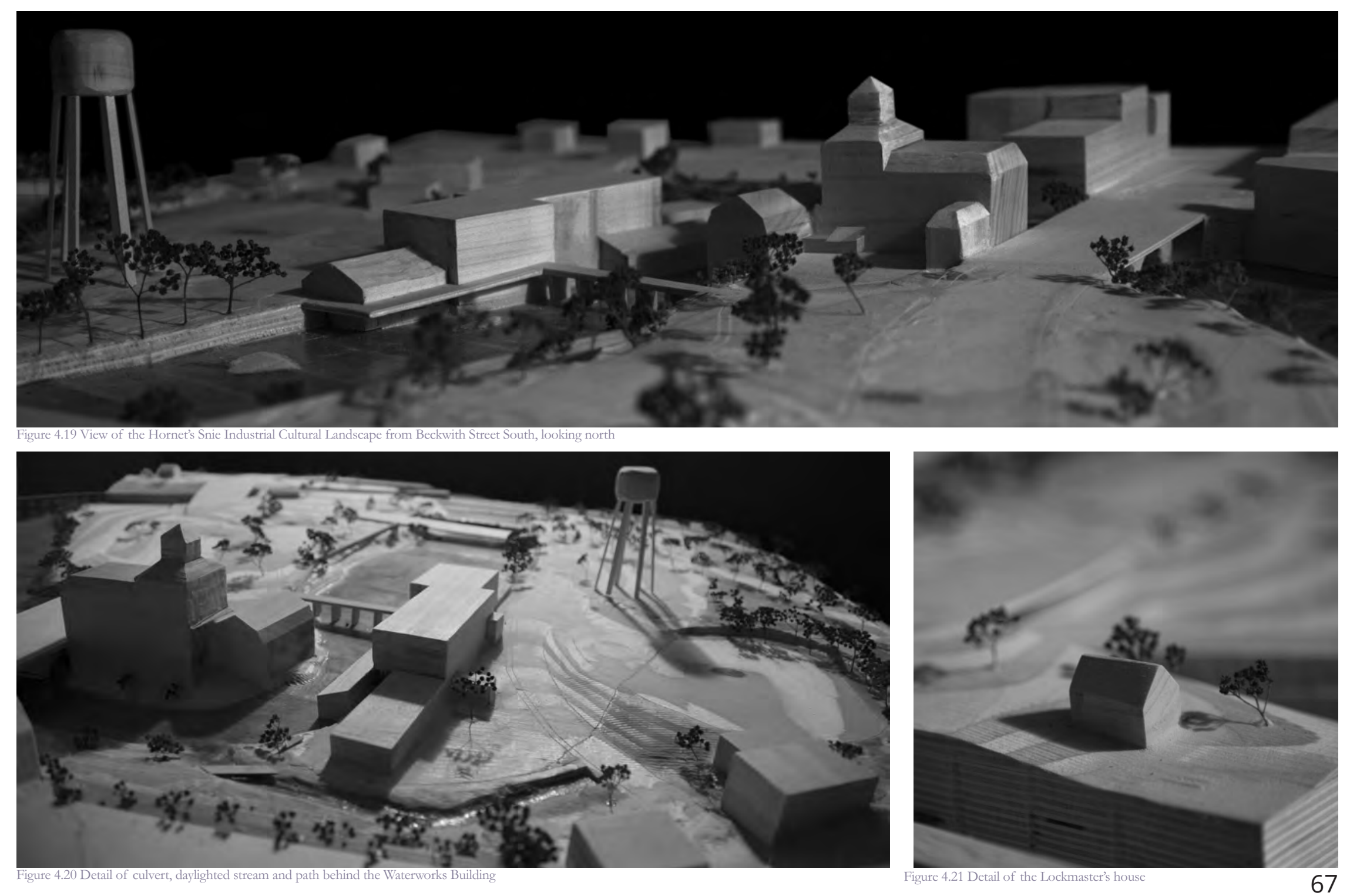


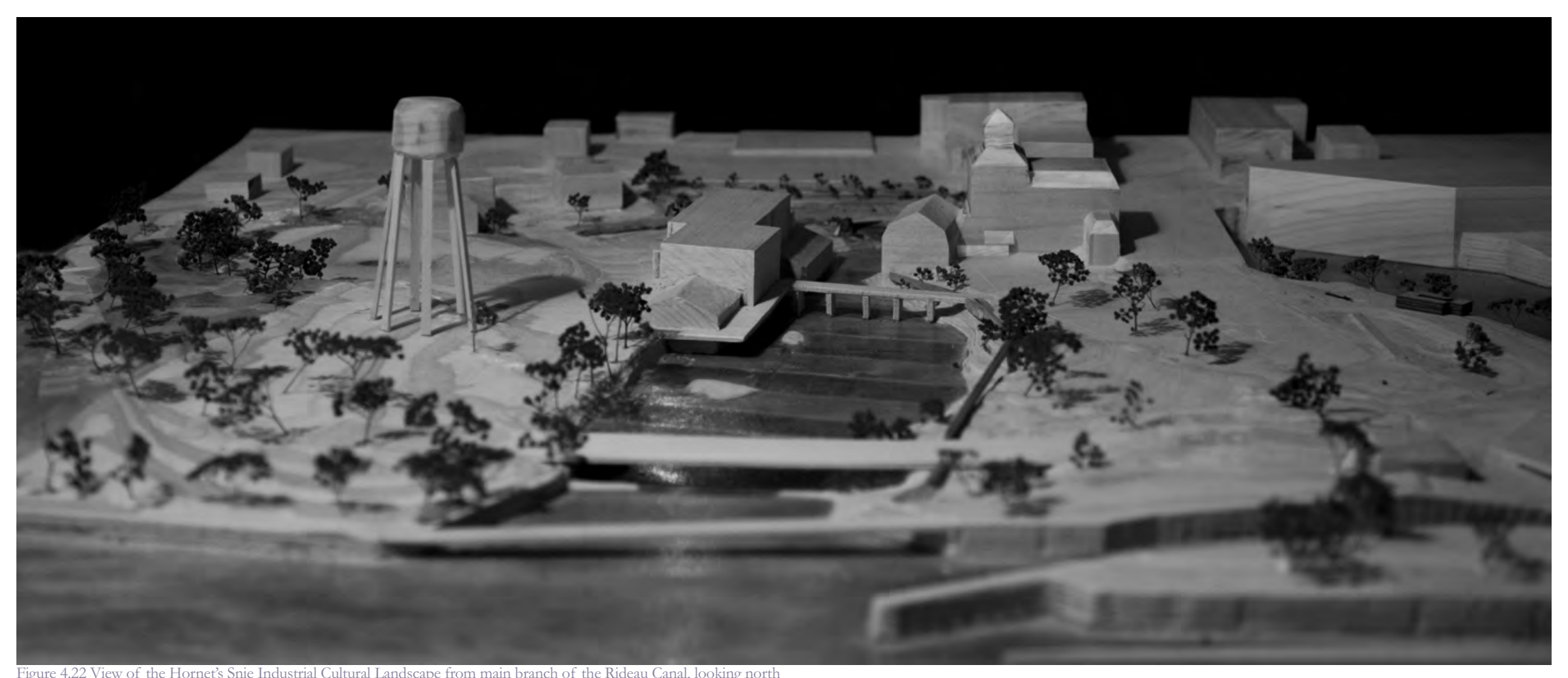


The floor of the West Mill has significant deflections and many openings to accommodate historic machinery (refer to chapter 2.4 Existing Conditions). The proposed rehabilitation involves installing a new level and soundproof floor on top of the historic floor (see figure 4.21). In addition to being reversible, this intervention allows the character-defining holes in the floor to become a feature of the ceiling below. Openings which have been patched with interesting materials (such as license plates) can be seen from above through glass openings in the new floor. 


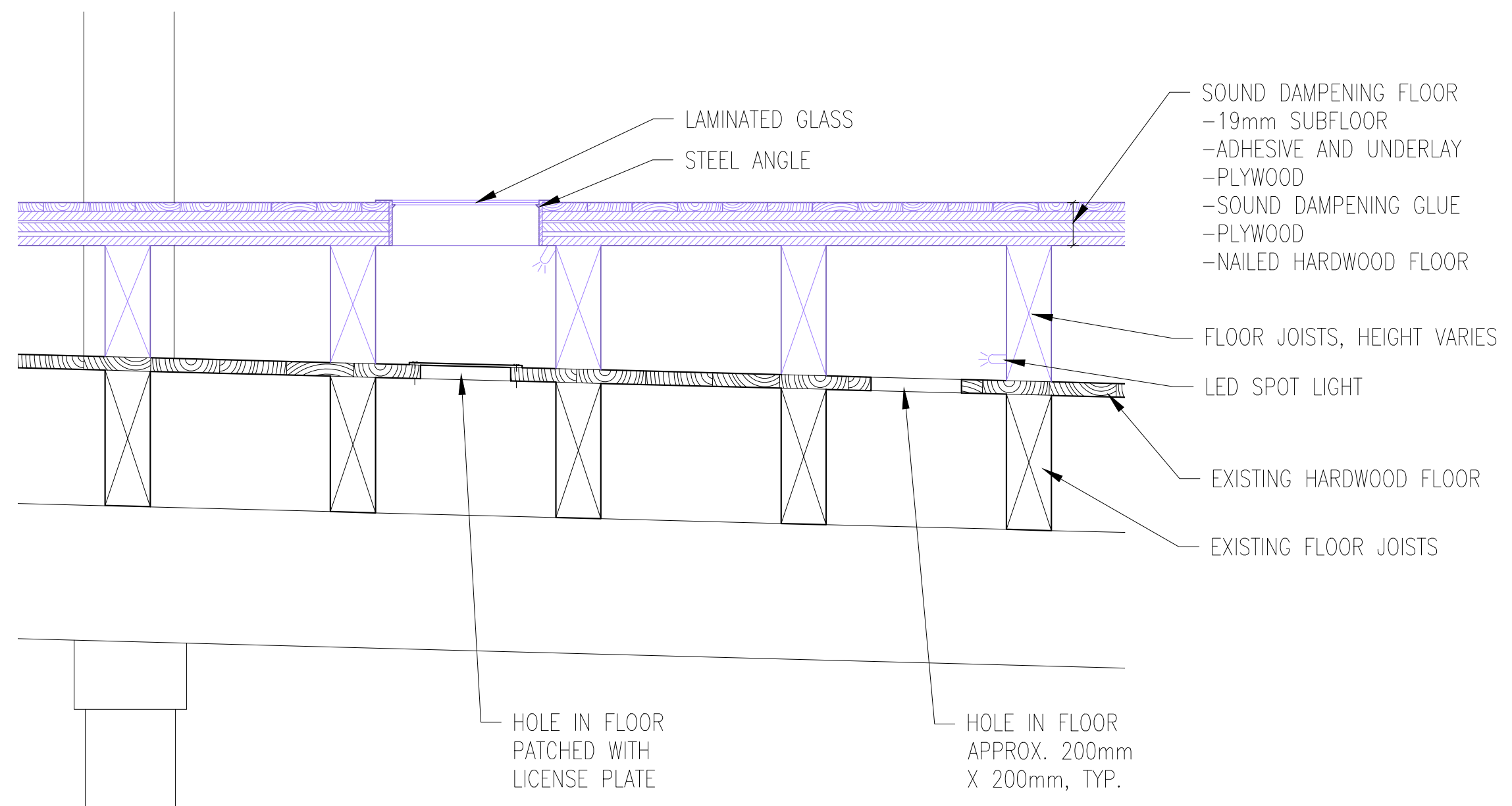

FLOOR REHABILITATION DETAIL

Figure 4.23 West Mill floor detail 1:15 


\section{Granary FaÇAde Replacement}

The granary was reconstructed in 1990 to accommodate the museum while appearing historically accurate from the exterior (with the exception of one small window). The values of this reconstruction lie mainly in its volume rather than the material fabric. Therefore, it is proposed to keep the existing concrete frame and replace the façade with a curtain wall and operable wood louvers (figure 4.22). This improves the quality of the work spaces by opening up views to the surrounding landscape and bringing daylight into the tower (refer to chapter 3.2.7 Design Strategies: Solar Shading). The façade is composed of $50 \%$ triple glazed windows and 50\% insulated spandrel panels to balance the benefits of daylighting with heating efficiency. Insulation and thermally broken connections minimize heat loss through the support frame cantilevered from the concrete frame. 

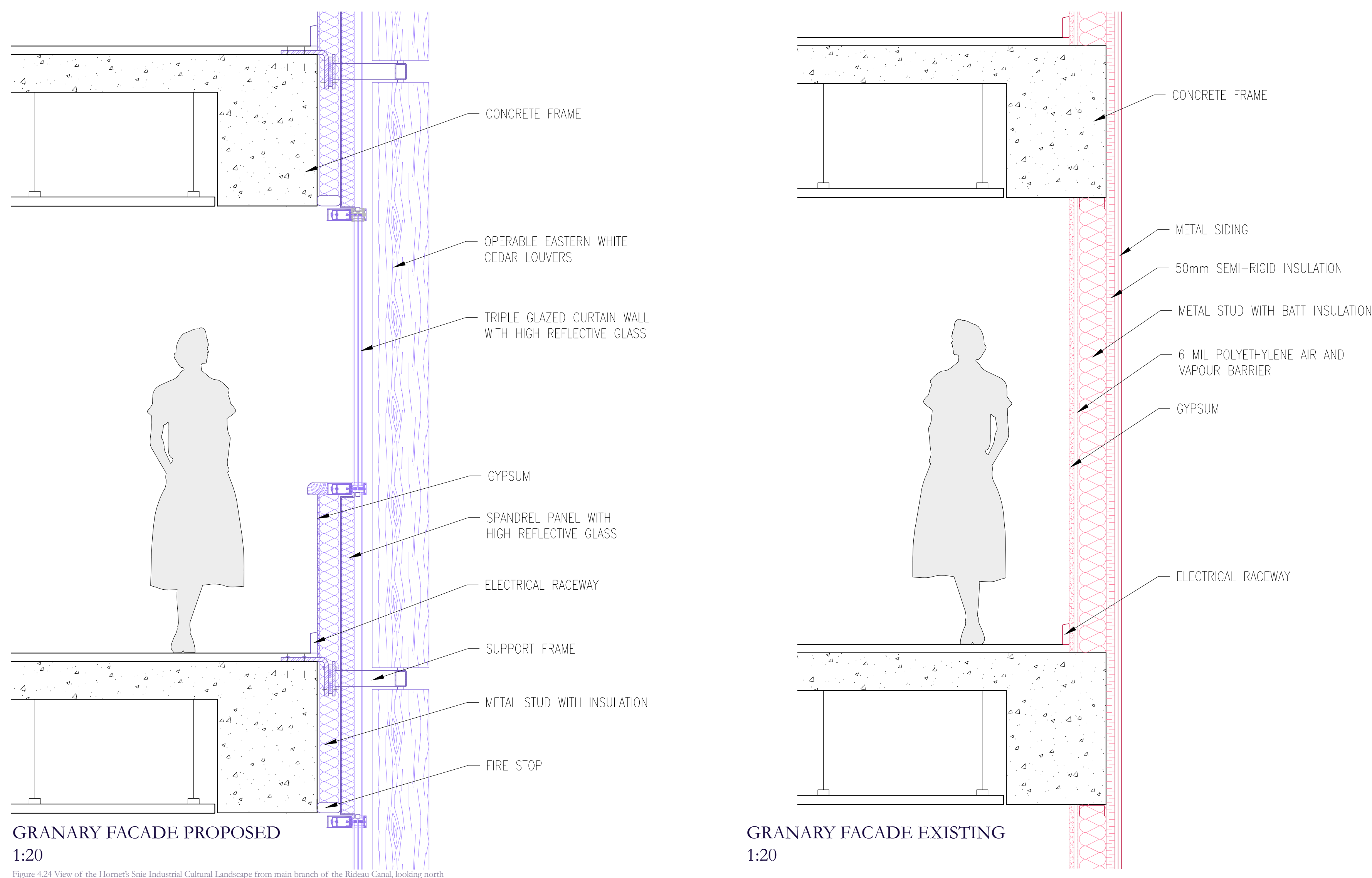


\section{Masonry Wall Rehabilitation}

Preliminary analysis suggests that interior insulation may be an appropriate strategy to improve energy efficiency of the Wood's Mill Complex. The masonry seems to perform well in the absence of heat and the insulated portion of the East Mill does not seem to have any issues (refer to chapter 2.4 Existing Conditions).

Historic England suggests using a vapour permeable wall assembly which does not rely on a vapour barrier which could be easily damaged (see figure 4.23). ${ }^{1}$ This means it is critical that the insulation and interior finishes use materials which allow vapour to move freely and that can absorb and release moisture.

Furthermore, this assembly can be installed in phases beginning with replacing the lime plaster and improving airtightness. This first phase should be applied to the interior of all masonry walls which are part of the building envelope. This will improve comfort and energy

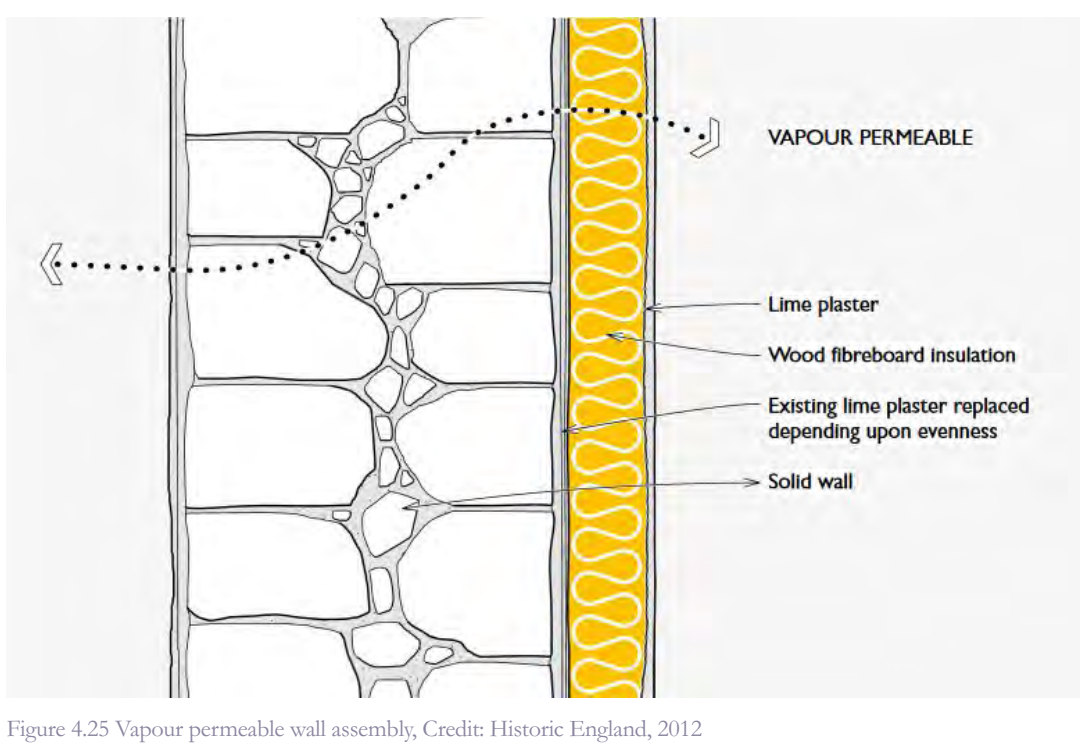
efficiency at minimal cost and be more historically accurate than the exposed masonry walls. The decision to add insulation to requires further analysis (see appendix F) to ensure compatibility.

1 Historic England, "Energy Efficiency and Historic Buildings: Insulating Solid Walls" (Historic England, March 30, 2012). 


\section{Maintenance, Monitoring, Commissioning \& Risk Mitigation}

Although it is not within the scope of this thesis to go in depth with these topics, they are integral components of the Dublin Principles (see figure 1.3 and appendix B). As with any heritage building, it is recommended to prepare and use a conservation plan which details maintenance, monitoring, and commissioning procedures and frequency.

Building maintenance is essential for environmental and economic efficiency since keeping components in good condition reduces energy consumption and need for major capital projects. ${ }^{1}$ Maintaining the character-defining elements optimizes the life of materials and preserves the cultural heritage values. ${ }^{2}$ Historic buildings which are well-maintained are better able to withstand the impacts of climate change such as flooding and extreme climatic incidents. ${ }^{3}$ (Horowitz et al., 2016)

Monitoring the performance and behaviour of a building can help such as whether or not to insulate masonry walls (appendix F). Periodic commissioning of mechanical systems ensures they are working as intended thereby increasing efficiency and reducing operating costs. Monitoring should be built into the rehabilitation project as well as a strategy (such as an art installation) to educate building users and encourage sustainable behaviour.

A formal risk analysis can be useful in mitigating impacts to heritage values of the site such as floods, earthquakes or high numbers of tourists. It should be noted that in 1990, the historic wood frame and floors of the East Mill and granary were replaced with a concrete frame structure. This could be problematic in the case of a severe earthquake (as shown in buildings with similar interventions in Italy and South America). ${ }^{4}$ Although Eastern Ontario is in an active seismic zone, the earthquakes with a magnitude above 5 are rare. ${ }^{5}$

to identify appropriate strategies to improve sustainable performance,

\footnotetext{
1 Federal Provincial Territorial Ministers of Culture and Heritage in Canada, Building Resilience

2 Ibid.

3 "Climate Change and Cultural Heritage Conservation: A Literature Review" (Association for Preservation Technology International, June 30, 2016),

4 Mariana Esponda, personal communication, 2017

5 Natural Resources Canada, "Earthquake Zones in Eastern Canada," February 10, 2016.
} 


$$
5 .
$$

Present \&

Communicate 


\section{INTERPRETATION StRategy}

Interpretation contributes to the sustainable conservation of heritage sites by promoting public understanding and participation in ongoing conservation efforts. The goal of interpretation is to communicate the meaning and facilitate appreciation of the Hornet's Snie Industrial Cultural Landscape for a wide audience while safeguarding its tangible and intangible values. ${ }^{1}$ Successful conservation requires public and corporate understanding of the site.

The Rideau Canal Visitor Centre is the primary facility dedicated to interpreting the outstanding universal values of the Rideau Canal. Bridging the gap between the history of the entire Rideau Canal and the former manufacturing landscapes of Smiths Falls, visitors can participate in the act of making by building canoes and snowshoes. Furthermore, the history of milling technology and waterpower can be explained in the basement of the West Mill, in the presence of the historic and modern equipment while watching the water enter and exit the building (figure 4.13).
The building itself can be thought of as a laboratory, a place of experimentation, observing, refining, and improving. Art installations created by building users can help visualize energy generation and use to raise awareness and promote efficient use of resources. Furthermore, installations monitor the movement of moisture through the walls to facilitate understanding of the hygrothermal properties of traditional building materials (such as stone) and the impacts of interventions such as adding insulation.

A river of flowers planted as a groundcover through the municipal parkland illustrates the original course of the river. Little blue star creeper (figure 5.1 and 5.2) is a low-maintenance perennial groundcover which blooms for 3 weeks in the spring and blends in with turf grass the rest of the year. Furthermore, since water is still flowing along this branch underground, the portion behind the Waterworks Building can be daylighted as it is released back into the Hornet's Snie (figure 5.3).

1 ICOMOS, "ICOMOS Ename Charter for the Interpretation and Presentation of Cultural Heritage Sites," 2008. 

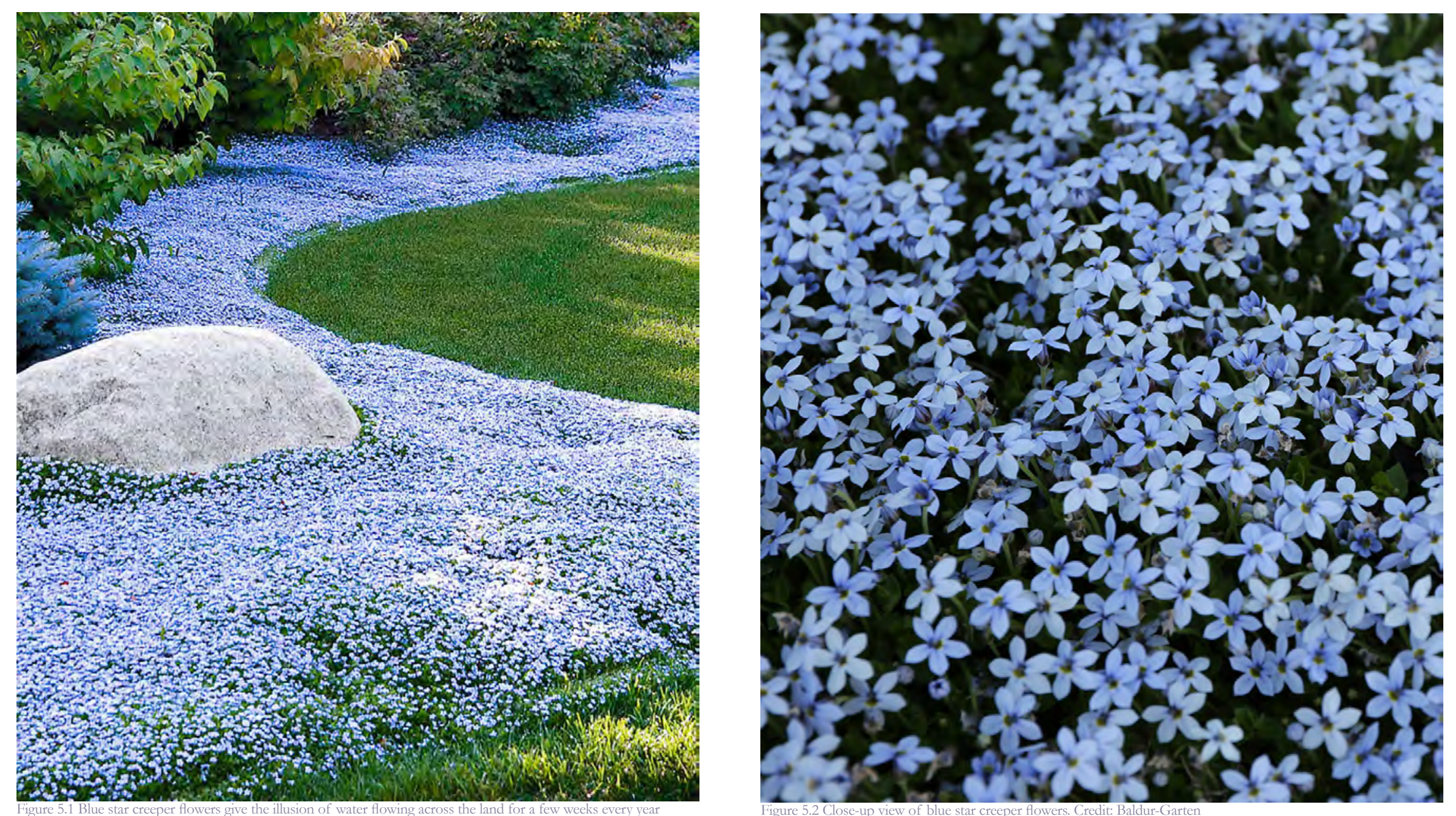


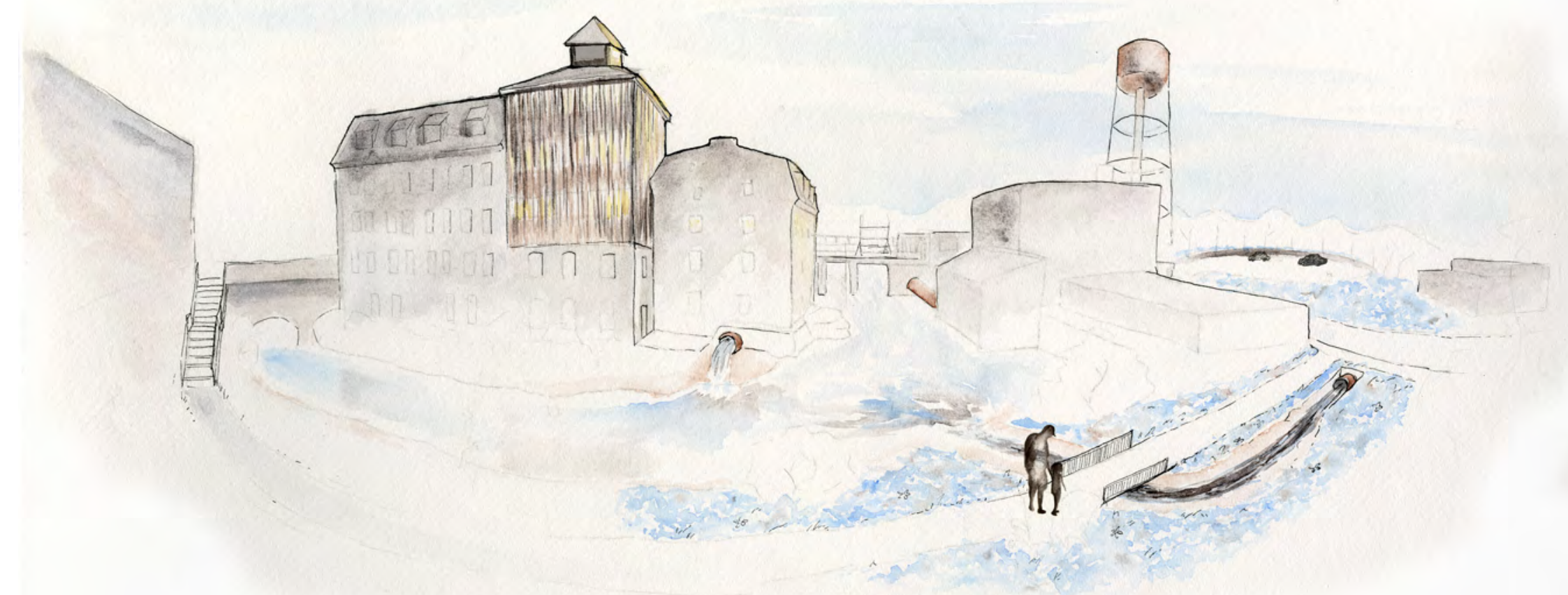


Relevance to Other Canadian Industrial Sites

Smiths Falls is representative of the nation-wide trends such as the collapse of small-town industry, and rural-to-urban migration. This puts industrial heritage across Canada at high risk for demolition, whether it is grain elevators in the prairies, lighthouses in the maritimes, or the old mills of Ontario and Quebec.

A census of Upper Canada (now called Ontario) 1860-1861 noted that there were 1853 mills in Ontario, including 494 grist and flour mills. ${ }^{1}$ The CANIND71 database lists 2600 water powered industrial sites in Ontario (including 553 grist mills) as well as 2939 water powered sites in Quebec, 2520 in the Maritimes and a total of 8051 in all of Canada in the year $1871 .^{2}$ It is estimated that there are approximately 120 old mills remaining in Ontario, many of which are at risk of demolition or need rehabilitation. ${ }^{3}$

The research in Smiths Falls is highly relevant to rural communities looking to conserve their old mills or other industrial sites and landscapes. Presenting and communicating this research builds public awareness and appreciation of industrial heritage and can contribute to achieving goals of sustainable development. ${ }^{4}$

\footnotetext{
“Census No. 13 - Upper Canada - Return of Mills, Manufacturers, Etc. for 1860-1861,” Ontario Mills Archival Information, SPOOM Canada, (1861).

2 University of Guelph, “CANIND71,” accessed January 11, 2017, http://sasintrnet.ccs.uoguelph.ca/cgi-bin/broker.

3 Robert Miller and David Sweeney (members of the Society for the Preservation of Old Mills - Canadian Chapter), in discussion with authors, January $10,2017$.

4 ICOMOS and TICCIH, "Dublin Principles," 2011.
} 
6.

CONCLUSION 
Regenerating the Heart of Smiths Falls

Repurposing the Wood's Mill Complex and interpretation of

the Hornet's Snie Industrial Cultural Landscape can build resilience in Smiths Falls as a source of employment and diversifying the economy. Giving new life to underused buildings can restore cultural vitality, especially when the new program supports the needs of the community. Reusing buildings brings inherent environmental benefits by reducing landfill waste, reducing demand for virgin materials, and maintaining cultural values. Memory and intangible heritage are essential components of cultural vitality. Although these are distinct from the building fabric, the tangible built heritage acts as an anchor for the intangible and can generate new memories and new values by engaging people in new ways. Table 5 demonstrates how the proposed project can create resilience in Smiths Falls by enhancing each of the four pillars of sustainability. In this way, a holistic sustainable approach to reusing industrial heritage can contribute to renewed interest, investment and delight in rural communities. 


\begin{tabular}{|c|c|c|c|c|}
\hline \multicolumn{5}{|c|}{ How to Build Resilience in Smiths Falls? } \\
\hline & Current Problems & Proposed Solutions & Demonstrated in the Project & Location \\
\hline \multirow{5}{*}{ 品 } & $\begin{array}{l}\text { sudden loss of most manufacturing } \\
\text { jobs; lack of quality year-round jobs }\end{array}$ & diversify the economy through heritage tourism & $\begin{array}{l}\text { enhance the Rideau Canal Visitor Centre with two new unique year-round } \\
\text { learning experiences; maintain Parks Canada offices for initial phase of } \\
\text { development }\end{array}$ & $\begin{array}{l}\text { Canoe- and snowshoe-building in West Mill ground floor (54 m2); virtual } \\
\text { simulation room in granary fourth floor; Parks Canada East Mill, all floors }\end{array}$ \\
\hline & lack of diversity in the local economy & $\begin{array}{l}\text { encourage innovation and entrepreneurship; provide } \\
\text { business training }\end{array}$ & $\begin{array}{l}\text { provide affordable, low-risk co-working spaces, private offices and access to } \\
\text { computer laboratory; banquet and events space ; art gallery/shop }\end{array}$ & $\begin{array}{l}\text { co-working West Mill third floor (12-18 people); private offices West Mill third } \\
\text { floor ( } 83 \mathrm{~m} 2) \text {; computer lab granary fourth floor( } 18 \text { people); banquet hall (100- } \\
140 \text { people); art gallery/shop West Mill ground floor }(128 \mathrm{~m} 2)\end{array}$ \\
\hline & $\begin{array}{l}\text { high unemployment rate, high } \\
\text { dependency on social assistance } \\
\text { (welfare) }\end{array}$ & $\begin{array}{l}\text { provide opportunities to learn new skills and start } \\
\text { new businesses; create new business and social } \\
\text { enterprises which are financially self-sustaining }\end{array}$ & $\begin{array}{l}\text { makerspace, digital fabrication lab and computer lab provide opportunities } \\
\text { to learn marketable skills }\end{array}$ & $\begin{array}{l}\text { makerspace granary third floor ( } 100 \mathrm{~m} 2) \text {; digital fabrication lab granary third } \\
\text { floor (27 } \mathrm{m} 2) \text {; computer lab granary fourth floor (18 people) }\end{array}$ \\
\hline & $\begin{array}{l}\text { lower tax base due to shrinking } \\
\text { population }\end{array}$ & $\begin{array}{l}\text { make town more desirable place to live (see social } \\
\text { and cultural) }\end{array}$ & $\begin{array}{l}\text { maintain and enhance cultural heritage values of the Wood's Mill Complex } \\
\text { and industrial cultural landscape }\end{array}$ & entire project \\
\hline & $\begin{array}{l}\text { vacant storefronts in central business } \\
\text { district }\end{array}$ & $\begin{array}{l}\text { Encourage business start-ups to locate in downtown } \\
\text { core }\end{array}$ & $\begin{array}{l}\text { provide affordable, low-risk co-working spaces, private offices and access to } \\
\text { computer laboratory }\end{array}$ & $\begin{array}{l}\text { co-working spaces West Mill third floor (12-18 people); private offices West Mill } \\
\text { third floor (83 m2); computer lab granary fourth floor(18 people); }\end{array}$ \\
\hline \multirow{3}{*}{ 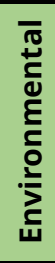 } & vacant buildings & repurpose buildings for contemporary use & $\begin{array}{l}\text { rehabilitate vacant West Mill for public use and electricity generation (500 } \\
\text { kW) }\end{array}$ & $\begin{array}{l}\text { public access to } 569 \mathrm{~m} 2 \text { of the West Mill; hydroelectric station West Mill } \\
\text { basement (159 m2) }\end{array}$ \\
\hline & carbon emissions and climate change & $\begin{array}{l}\text { sustainably retrofit building envelope; generate clean } \\
\text { renewable electricity }\end{array}$ & $\begin{array}{l}\text { test and investigate retrofit options which include interior insulation; install } \\
\text { hydroelectric turbine ( } 500 \mathrm{~kW})\end{array}$ & $\begin{array}{l}\text { retrofit interior of all masonry walls which are part of the building envelope; } \\
\text { hydroelectric station West Mill basement }\end{array}$ \\
\hline & andfill waste and pollution & encourage a culture of reuse and repair & $\begin{array}{l}\text { minimal intervention approach to rehabilitation; providing tools and } \\
\text { expertise at the makerspace for do-it-yourself projects and upcycling }\end{array}$ & makerspace tools in granary third floor \\
\hline \multirow{4}{*}{ 产 } & $\begin{array}{l}\text { homeless youth, and youth doing } \\
\text { drugs and alcohol, high teen } \\
\text { pregnancy rate }\end{array}$ & $\begin{array}{l}\text { live youth 'something to do;' provide job } \\
\text { opportunities for youth; build healthy relationships } \\
\text { across generations }\end{array}$ & $\begin{array}{l}\text { makerspace and computer lab provide opportunities to engage in art, learn } \\
\text { new skills, and build intergenerational relationships with locals and visitors }\end{array}$ & $\begin{array}{l}\text { makerspace granary third floor (100 } \mathrm{m} 2) \text {; digital fabrication lab granary third } \\
\text { floor (27 m2); computer lab granary fourth floor (18 people) }\end{array}$ \\
\hline & $\begin{array}{l}\text { youth moving away to large urban } \\
\text { centres }\end{array}$ & $\begin{array}{l}\text { Engage youth and help them to remake the } \\
\text { community; collaborate with local schools. }\end{array}$ & $\begin{array}{l}\text { spaces dedicated to arts, technology and business accompanied by } \\
\text { mentoring to equip youth to build local careers }\end{array}$ & $\begin{array}{l}\text { West Mill ground floor and third floor; granary, third and fourth floors (total } 622 \\
\text { m2) }\end{array}$ \\
\hline & intolerance for minority groups & $\begin{array}{l}\text { celebrate diversity; foster relationships between } \\
\text { indigenous and non-indigenous people; interpret } \\
\text { heritage values from multiple perspectives }\end{array}$ & $\begin{array}{l}\text { snowshoe and canoe-building workshops to alternate between modern and } \\
\text { indigenous techniques }\end{array}$ & Canoe- and snowshoe-building in West Mill ground floor (54 m2) \\
\hline & $\begin{array}{l}\text { shrinking population, especially } \\
\text { among the working population }\end{array}$ & make town more desirable place to live and visit & $\begin{array}{l}\text { conducting a survey of } 15 \text { locals and tourists to understand and meet their } \\
\text { needs and desires }\end{array}$ & see appendix G \\
\hline \multirow{4}{*}{$\begin{array}{l}\overline{\frac{\pi}{3}} \\
\frac{\bar{m}}{3}\end{array}$} & vacant industrial/heritage buildings & repurpose buildings for contemporary use & $\begin{array}{l}\text { maintain and enhance cultural heritage values of the Wood's Mill Complex } \\
\text { and industrial cultural landscape; encourage entrepreneurship }\end{array}$ & $\begin{array}{l}\text { enhance values of entire site; entrepreneurship focus in West Mill ground floor } \\
\text { and third floor, granary third and fourth floors (total } 622 \mathrm{~m} 2 \text { ) }\end{array}$ \\
\hline & $\begin{array}{l}\text { difficult to understand industrial } \\
\text { heritage of Smiths Falls }\end{array}$ & $\begin{array}{l}\text { interpret local industrial heritage and the evolving } \\
\text { industrial cultural landscape }\end{array}$ & $\begin{array}{l}\text { use flowers to trace the historic path of the river; restore the flow of water } \\
\text { through the basement of the West Mill; emphasize movement of water } \\
\text { throughout design proposal }\end{array}$ & entire project \\
\hline & $\begin{array}{l}\text { tourism industry shuts down outside } \\
\text { of summer boating season }\end{array}$ & $\begin{array}{l}\text { enhance museum so it is more desirable for repeat } \\
\text { visits; diversify tourist experience to include the arts }\end{array}$ & $\begin{array}{l}\text { makerspace and computer labs to host workshops; banquet and events } \\
\text { space with flexible layout; art gallery and shop; canoe- and snowshoe- } \\
\text { building workshop }\end{array}$ & entire West Mill and granary \\
\hline & $\begin{array}{l}\text { lack of educational opportunities for } \\
\text { artists }\end{array}$ & $\begin{array}{l}\text { promote interaction and reciprocal learning between } \\
\text { residents and visitors }\end{array}$ & $\begin{array}{l}\text { art gallery/shop provides locals with a place to display and sell their } \\
\text { creations; makerspace, computer lab and workspaces for visitors and locals } \\
\text { to share ideas }\end{array}$ & $\begin{array}{l}\text { art gallery/shop West Mill ground floor (128 m2); makerspace granary third floor } \\
(100 \mathrm{~m} 2) ; \text { computer lab granary fourth floor (18 people); co-working West Mill } \\
\text { third floor (12-18 people); }\end{array}$ \\
\hline
\end{tabular}




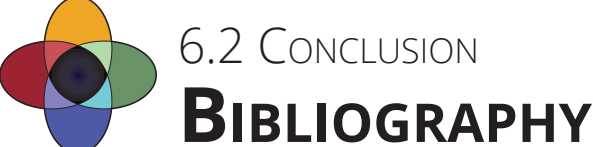

Algonquins of Ontario. "Our Proud History,” 2013. http://www.tanakiwin.com/ algonquins-of-ontario/our-proud-history/.

“Overview of Treaty Negotiations," 2013. http://www.tanakiwin.com/ our-treaty-negotiations/overview-of-treaty-negotiations/.

Artscape. “About Artscape,” 2011. http:/ /www.torontoartscape.org/about-artscape.

$$
\text { “Artscape Launchpad,” 2017. http://www.artscapelaunchpad.ca/the-place/. }
$$

Association for Preservation Technology International. "OSCAR: Online Sustainable Conservation Assistance Resource | the Guide for Best Sustainable Practices in Preservation Architecture.” Accessed August 28, 2017. http://oscar-apti.org/.

Balen, Koenraad van. "The Nara Grid: An Evaluation Scheme Based on the Nara Document on Authenticity.” APT Bulletin 39, no. 2/3 (2008): 39-45.

Barry Padolsky Architect ltd. "Restoration and Adaptive Re-Use: Wood's Mill Complex." Architectural concept. Ottawa, November 28, 1988.

Berens, Carol. Redeveloping Industrial Sites: A Guide for Architects, Planners, and Developers. Hoboken, N.J: Wiley, 2010.

Canada’s Historic Places. "East Mill.” Canadian Register of Historic Places, 2008. http:/ / www.historicplaces.ca/en/rep-reg/place-lieu.aspx?id=10345\&pid=0.

"West Mill." Canadian Register of Historic Places, 2008. http://www. historicplaces.ca/en/rep-reg/place-lieu.aspx?id=10370\&pid $=0$.

"Canadian Chapter - Old Mill Society SPOOM." Accessed January 11, 2017. https://www.facebook.com/groups/180453978748510/?multi_ permalinks $=1064492570344642 \% 2 \mathrm{C} 1064490907011475 \&$ notif_t $=$ group_ activity\&notif_id=1484090370107330.
Census. "No. 13 - Upper Canada - Return of Mills, Manufacturers, Etc. for 1860 1861.” SPOOM Canada, 1861. http://www.spoomcanada.ca/Research/index.htm.

"Climate Change and Cultural Heritage Conservation: A Literature Review." Association for Preservation Technology International, June 30, 2016.

Commonwealth Historic Resource Management Limited. "A History of the Wood's Mills Complex Smiths Falls," April 1988.

Federal Provincial Territorial Ministers of Culture and Heritage (Canada). Building Resilience: Practical Guidelines for the Sustainable Rehabilitation of Buildings in Canada, 2016. http://www.historicplaces.ca/pdf/Building\%20Resilience.pdf.

Standards and Guidelines for the Conservation of Historic Places in Canada: A Federal, Provincial and Territorial Collaboration. Ottawa: Canada's Historic Places, 2010. http://www.historicplaces.ca/media/18072/81468-parks-s+g-eng-web2.pdf.

Hawkes, Jon. The Fourth Pillar of Sustainability: Culture's Essential Role in Public Planning. Common Ground, 2001.

Hawley, Jan. “Win This Space.” Smiths Falls, December 1, 2016

“Heritage | Smiths Falls - Protected Properties.” Accessed March 24, 2017. http:// www.heritagesmithsfalls.ca/properties.html\#pt3.

Historic England. "Energy Efficiency and Historic Buildings: Insulating Solid Walls." Historic England, March 30, 2012. http://historicengland.org.uk/images-books/ publications/eehb-insulating-solid-walls/.

HotelPlanner. "Meeting Space Calculator," 2017. https://www.hotelplanner.com/ Common/Popups/SpaceCalculator.cfm.

ICOMOS. "ICOMOS Ename Charter for the Interpretation and Presentation of 
Cultural Heritage Sites,” 2008. http://www.enamecharter.org/index.html.

ICOMOS, and The International Committee for the Conservation of the Industrial Heritage. "Principles for the Conservation of Industrial Heritage Sites, Structures, Areas and Landscapes," November 28, 2011. http:/ /www.international.icomos.org/ Paris2011/GA2011_ICOMOS_TICCIH_joint_principles_EN_FR_final_20120110. pdf.

Kim Whytock \& Associates Inc. "Rideau Canal Heritage Corridor Visitor Experience Opportunities Concept: Executive Summary," 2013. http://valleycfdc.com/wpvalley/ wp-content/uploads/2014/02/Executive-Summary.pdf.

"Rideau Ferry to Merrickville Reach - VEOC Discussion Highlights," 2013. http://valleycfdc.com/wpvalley/wp-content/uploads/2014/02/BW-R4-RideauFerry-to-Merrickville-Reach.pdf.

LeBlanc, Francois. “Main Street Canada Heart and Soul.” Accessed September 7, 2016. http://ip51.icomos.org/ fleblanc/publications/pub_2008_heart_and_soul.html.

Lstiburek, Joseph. "BSD-106: Understanding Vapor Barriers." Building Science Corporation, April 15, 2011. https://buildingscience.com/documents/digests/bsd106-understanding-vapor-barriers.

Municipal Heritage Committee. "Heritage Properties of Interest Report." Smiths Falls, June 22, 2016. https://smithsfalls.ca/public_docs/events/Heritage $\% 20$ Properties $\% 20$ of $\% 20$ Interest $\% 20$ Report.pdf.

Nääs Fabriker. “Nääs Fabriker.” Nääs Fabriker. Accessed October 10, 2016. http:// www.naasfabriker.se/.

National Trust for Canada. "Main Street®," 2015. https:/ / www.nationaltrustcanada. $\mathrm{ca} /$ resources/regeneration/main-street.

Ontario's Highlands Tourism Organization. "Tourism Starts with You! Making Shift Happen in Ontario's Highlands,” April 2014. http:/ / ohto.ca/wp-content/uploads/ OHTO_TSWYKit_Web-Pages.pdf.

Pandey, Bikash, and Ajoy Karki. Hydroelectric Energy: Renewable Energy and the
Environment. CRC Press, 2016.

Parks Canada. Nomination of the Rideau Canal by the Government of Canada, 2006 for Inscription on the World Heritage List. Government of Canada, 2006.

" "Rideau Canal National Historic Site: The History of the Rideau Canal," August 2, 2012. http://www.pc.gc.ca/eng/lhn-nhs/on/rideau/natcul/natcul2.aspx.

Passfield, Robert. Building The Rideau Canal. 1 edition. Markham, Ont.: Fitzhenry \& Whiteside, 2003.

Plodinec, M. John. "Definitions of Resilience: An Analysis." Community and Regional Resilience Institute (CARRI), 2009.

Rideau Roundtable. “The Rideau Roundtable: Voyageur Canoe Tours,” 2016. http:/ / www.rideauroundtable.ca/voyageur.html.

Rubin, Jeff. “The Future Looks Bleak for Ontario's Manufacturing Sector.” The Globe and Mail, December 30, 2013. http://www.theglobeandmail.com/reporton-business/economy/the-future-looks-bleak-for-ontarios-manufacturing-sector/ article16132219/.

Shorefast Foundation. "Shorefast Foundation." Shorefast Foundation. Accessed January 4, 2017. http://shorefast.org/about-us/overview/.

Smiths Falls and District Centre for Youth. "About SFDCY." Accessed November 29, 2016. http://www.sfdcy.ca/newsite/about-sfdcy/.

Statistics Canada. "Census Subdivision of Smiths Falls," February 8, 2012. https:// www12.statcan.gc.ca/census-recensement/2011/as-sa/fogs-spg/Facts-csd-eng. cfm?LANG=Eng\&GK=CSD\&GC=3509004.

Stovel, Herb, Nick Adams, Barbara Humphreys, David Jacques, Jim Mountain, Meryl Oliver, and Rob Snetzinger. "The Cultural Landscapes of the Rideau Canal Corridor: Phase II Study.” Institute for Heritage Education study team, 1998.

The Great Trail. "Lanark County." TC Trail, May 19, 2016. https://thegreattrail.ca/ explore-the-map/. 
The International Committee for the Conservation of the Industrial Heritage. "The Nizhny Tagil Charter for the Industrial Heritage," July 2003. http://www.icomos. org/18thapril/2006/nizhny-tagil-charter-e.pdf.

The Rideau Roundtable. "Facts about the Rideau,” 2016. http:/ /www.rideauroundtable. $\mathrm{ca} /$ facts.html

Town of Smiths Falls. "Smiths Falls Strategy to Welcome Newcomers," 2012. https:/ www.smithsfalls.ca/public_docs/documents/Smiths $\% 20$ Falls $\% 20$ Strategy $\% 20$ for $\% 20$ welcoming $\% 20$ newcomers11.pdf.

UNESCO. "Text of the Convention for the Safeguarding of the Intangible Cultural Heritage,” 2016. https://ich.unesco.org/en/convention\#art2.

UNESCO World Heritage Centre. "Rideau Canal.” UNESCO World Heritage Centre, 2016. http://whc.unesco.org/en/list/1221/.

Van Balen, Koenraad. "The Nara Grid: An Evaluation Scheme Based on the Nara Document on Authenticity.” APT Bulletin 39, no. 2/3 (2008): 39-45.

Watson, Ken W. A History of the Rideau Lockstations. Friends of the Rideau, 2000. http://www.rideau-info.com/canal/books/book-lockhistory.html.

Wrigglesworth, Trad. "A Novel Approach to Revitalization - the Story of Nääs Business Centre.” In When People Matter, edited by Anders Törnqvist and Peter Ullmark, 178-83. Sweden : Solna, Sweden: Swedish Council for Building Research ; Distribution, Svensk Byggtjänst, 1989. 
ApPENDICES 


\section{Giossar}

Authenticity - not false or imitation (Merriam-Webster, 2017). Depending on the nature of the cultural heritage, its cultural context, and its evolution through time, authenticity judgments may be linked to the worth of a great variety of sources of infor mation. Aspects of the sources may include form and design, materials and substance, use and function, traditions and techniques, location and setting, and spirit and feeling, and other internal and external factors. The use of these sources permits elaboration of the specific artistic, historic, social, and scientific dimensions of the cultural heritage being examined. (Nara Document on Authenticity, 1994)

Building envelope - the physical separation (walls, roofs, foundations, windows, etc.) between the conditioned interior space of a building and the unconditioned exterior.

Building resiliency - The capacity of a building to continue to function and operate under extreme conditions, such as (but not limited to) extreme temperatures, sea level rise, natural disasters, etc. As the built environment faces the impending effects of global climate change, building owners, designers, and builders can design facilities to optimize building resiliency. (Federal Provincial Territorial Ministers of Cultural Heritage in Canada, "Building Resilience," 2016)

Character-defining elements - The materials, forms, location, spatial configurations, uses, and cultural associations or meanings that contribute to the heritage value of an historic place, which must be retained in order to preserve its heritage value. (Federal Provincial Territorial Ministers of Cultural Heritage in Canada, 2016)

Commissioning - To verify and document that building systems and assemblies are planned, designed, installed, tested, operated and maintained to meet the owner's requirements.

Conservation - All actions or processes that are aimed at safeguarding the characterdefining elements of a cultural resource so as to retain its heritage value and extend its physical life. This may involve "preservation," "rehabilitation," "restoration," or a combination of these actions or processes.
Cultural landscape - Any geographical area that has been modified, influenced, or given special cultural meaning by people. (Federal Provincial Territorial Ministers of Cultural Heritage in Canada, "Standards and Guidelines," 2010)

Culture - the social production and transmission of identities, meanings, knowledge, beliefs, values, aspirations, memories, purposes, attitudes and understanding; the 'way of life' of a particular set of humans: customs, faiths and conventions; codes of manners, dress, cuisine, language, arts, science, technology, religion and rituals; norms and regulations of behaviour, traditions and institutions. (Hawkes, 2001)

Daylighting - exposing an underground stream or river to daylight

Embodied energy - The total expenditure of energy involved in the creation of both the building and its constituent materials. Note: the energy expended to build the structure is 15 to 40 times its annual energy use. Current ratings systems, in measuring annual energy/operating costs, do not account for this embodied energy. (Federal Provincial Territorial Ministers of Cultural Heritage in Canada, 2016)

Heritage value - The aesthetic, historic, scientific, cultural, social or spiritual importance or significance for past, present or future generations. The heritage value of an historic place is embodied in its character-defining materials, forms, location, spatial configurations, uses and cultural associations or meanings. (Federal Provincial Territorial Ministers of Cultural Heritage in Canada, 2016)

Hygrothermal - of or relating to a combination of moisture and heat (MerriamWebster, 2017)

Industrial heritage - sites, structures, complexes, areas and landscapes as well as the related machinery, objects or documents that provide evidence of past or ongoing industrial processes of production, the extraction of raw materials, their transformation into goods, and the related energy and transport infrastructures. Industrial heritage reflects the profound connection between the cultural and natural environment, as 
industrial processes - whether ancient or modern - depend on natural sources of raw materials, energy and transportation networks to produce and distribute products to broader markets. It includes both material assets - immovable and movable -, and intangible dimensions such as technical know $\square$ how, the organization of work and workers, and the complex social and cultural legacy that shaped the life of communities and brought major organizational changes to entire societies and the world in general. (ICOMOS-TICCIH, "Dublin Principles," 2011)

Infrared thermography - a method of non-destructive testing which detects in frared energy (heat) emitted from an object and converts that to an image which can be used to calculate temperature.

Inherently sustainable features - Characteristics of a building or site that, through their design, physical materials or building or natural systems, embody principles of sustainability. (Federal Provincial Territorial Ministers of Cultural Heritage in Canada, 2016)

Intangible heritage - the practices, representations, expressions, knowledge, skills as well as the instruments, objects, artefacts and cultural spaces associated therewith - that communities, groups and, in some cases, individuals recognize as part of their cultural heritage. This intangible cultural heritage, transmitted from generation to generation, is constantly recreated by communities and groups in response to their environment, their interaction with nature and their history, and provides them with a sense of identity and continuity, thus promoting respect for cultural diversity and human creativity. (UNESCO, "Convention for the Safeguarding of the Intangible Cultural Heritage," 2016

Interpretation - refers to the full range of potential activities intended to heighten public awareness and enhance understanding of cultural heritage site. These can include print and electronic publications, public lectures, on-site and directly related off-site installations, educational programmes, community activities, and ongoing research, training, and evaluation of the interpretation process itself. (Ename Charter)

Laser scanner - a piece of survey equipment which uses a laser to rapidly capture the geometry of objects, buildings and landscapes. Also called lidar.

Makerspace - a place where people with shared interests can gather together to create, invent, and learn while benefiting from shared ideas, equipment and knowledge.

Minimum intervention - The course of action that applies the most benign physical impacts to achieve the longest-term protection of a building's characteristics and attributes while allowing compatible functional goals to be met. (Federal Provincial Territorial Ministers of Cultural Heritage in Canada, 2016)

Nara grid - a tool for identifying and organizing layerd heritage values to preserve authenticity of historic places. This tool is derived from the Nara Document for Authenticity. (van Balen, 2008)

Point cloud - a three-dimensional digital record of the landscape which captures the spatial relationships between the industrial structures and the landscape

Preservation - he action or process of protecting, maintaining, and/or stabilizing the existing materials, form, and integrity of a historic place or of an individual component while protecting its heritage value. (Federal Provincial Territorial Ministers of Cultural Heritage in Canada, 2016)

Rehabilitation - The action or process of making possible a continuing or compatible contemporary use of a historic place or an individual component while protecting its heritage value. (Federal Provincial Territorial Ministers of Cultural Heritage in Canada, 2016)

Restoration - The action or process of accurately revealing, recovering, or representing the state of a historic place or of an individual component as it appeared at a particular period in its history while protecting its heritage value. (Federal Provincial Territorial Ministers of Cultural Heritage in Canada, 2016)

Resilience - the capability to anticipate risk, limit impact, and bounce back rapidly through survival, adaptability, evolution, and growth in the face of turbulent change (Plodinec, 2009)

\section{Snie - dry flood channel}

Social sustainability - the ability of a community to develop processes and structures which support the needs of current and future members. Dimensions of social sustainability include equity, diversity, social cohesion, quality of life, democracy and 
governance, and maturity.

Sustainability/sustainable - The capacity of systems and processes to endure with minimal degradation of ecosystems and quality of life. A group of objectives (economic, social and environmental) that must be coordinated and addressed to ensure the long term viability of communities and the planet (Federal Provincial Territorial Ministers of Cultural Heritage in Canada, 2016)

Sustainable development - Organizing principle for human life on a finite planet. It posits a desirable future state for human societies in which living conditions and resource-use meet human needs without undermining the sustainability of natural systems and the environment, so that future generations may also have their needs met. For the sustainable development of existing and heritage buildings, specific considerations for long life of materials and assemblies, "loose fit," (or the ability to adapt to new standards, uses and circumstances ), local sourcing of materials and trades, and low ecological impact through retention of embodied energy and avoided impacts associated with re-use of still-sound building materials ) should also apply. (Federal Provincial Territorial Ministers of Cultural Heritage in Canada, 2016)

Total station - a piece of survey equipment which uses a laser to measure slope and distance to any particular spot.

Vapour barrier/vapour retarder - part of the building envelope which retards the migration of water vapour. Where it is located in an assembly and its permeability is a function of climate, the characteristics of the materials that comprise the assembly and the interior conditions. Vapor barriers are not typically intended to retard the migration of air. That is the function of air barriers. (Building Science Corporation, "Understanding Vapor Barriers," 2011)

Vapour permeable - a component or assembly which allows water vapour to move freely 
Appdendix B

Dublin Principles 


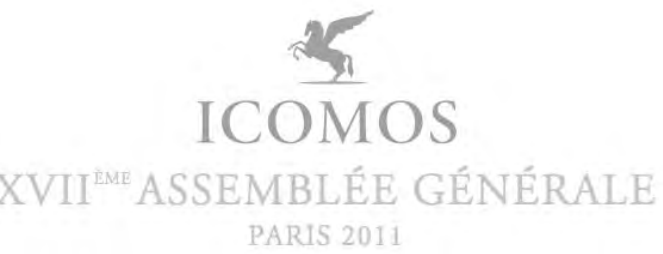

\section{Joint ICOMOS - TICCIH Principles for the Conservation of Industrial Heritage Sites, Structures, Areas and Landscapes}

\author{
«The Dublin Principles»
}

Adopted by the 17th ICOMOS General Assembly on 28 November 2011

\section{Preamble}

Around the World, a great diversity of sites, structures, complexes, cities and settlements, areas, landscapes and routes bear witness to human activities of industrial extraction and production. In many places, this heritage is still in use and industrialisation is still an active process with a sense of historical continuity, while in other places it offers archaeological evidence of past activities and technologies. Besides the tangible heritage associated with industrial technology and processes, engineering, architecture and town-planning, it includes many intangible dimensions embodied in the skills, memories and social life of workers and their communities.

The global process of industrialisation observed over the past two centuries constitutes a major stage of human history, making its heritage particularly important and critical to the Modern World. Precursors and beginnings of industrialisation can be recognized in many parts of the world well back into ancient times through active or archaeological sites, and our attention extends to any examples of such process and its heritage. However, for our purposes, these joint principles' primary interests coincide with the common notions of the Modern Era Industrial Revolution, marked by distinctive and dedicated production, transportation and power-generating or harnessing processes and technologies, trade and commercial interactions, and new social and cultural patterns.

\section{Principes conjoints ICOMOS-TICCIH pour la conservation des sites, constructions, aires et paysages du patrimoine industriel}

\author{
«Les principes de Dublin»
}

Adoptées par la 17e Assemblée générale de l'ICOMOS le 28 novembre 2011

\section{Préambule}

À travers le monde, la vaste diversité de sites, de constructions, de complexes, de villes et d'établissements, d'aires, de paysages ou de routes témoignent d'activités humaines d'extraction et de production industrielles. En de nombreux endroits, ce patrimoine est en opération et l'industrialisation constitue un processus actif chargé de continuité historique ; ailleurs, des ressources archéologiques révèlent les activités et technologies passées. Au patrimoine matériel lié aux procédés et techniques de l'industrie, du génie civil, de l'architecture ou de l'urbanisme, s'ajoute un patrimoine immatériel lié aux savoir-faire, à la mémoire ou à la vie sociale des ouvriers et de leurs communautés.

Le processus global d'industrialisation observé au cours des deux derniers siècles constitue une étape majeure de l'histoire humaine et son patrimoine revêt une importance significative dans le monde contemporain. En plusieurs parties du monde, les précurseurs et les débuts de l'industrialisation sont reconnus, remontant aux périodes anciennes, par des sites archéologiques ou actifs. Ces Principes conjoints s'intéressent à tout exemple de ce processus et de son patrimoine. Toutefois, l'intérêt premier de ces principes conjoints correspond aux concepts reconnus de Révolution industrielle de l'ère moderne, marquée par le développement et l'utilisation de processus et de technologies en matière de production, de transport et de génération d'énergie, d'échanges commerciaux et de pratiques sociales ou culturelles. 
The industrial heritage is highly vulnerable and often at risk, often lost for lack of awareness, documentation, recognition or protection but also because of changing economic trends, negative perceptions, environmental issues or its sheer size and complexity. Yet, by extending the life-cycle of existing structures and their embodied energy, conservation of the built industrial heritage, can contribute to achieving the goals of sustainable development at the local, national and international levels. It touches the social as well as the physical and environmental aspects of development and should be acknowledged as such.

Over the past decades, growing research, international and interdisciplinary cooperation as well as community initiatives have greatly contributed to a better appreciation of the industrial heritage and increased collaboration between stewards, stakeholders and professionals. This progress has benefitted from the development of a corpus of international references and guidelines by ICOMOSthe International Council on Monuments and Sites, and the implementation of international recommendations and instruments such as the World Heritage Convention adopted by UNESCO in 1972. In 2003, The International Committee for the Conservation of Industrial Heritage (TICCIH) adopted its Nizhny Tagil Charter for the Industrial Heritage, a first international reference text of such recognition to guide protection and conservation in the field.
Le patrimoine industriel est très vulnérable, menacé de disparaître faute de sensibilité, de connaissance, de reconnaissance ou de protection, sous l'effet d'une économie en mutation, de perceptions négatives, d'enjeux environnementaux ou de sa propre taille ou complexité. La conservation du patrimoine bâti industriel prolonge pourtant la vie utile des constructions et de l'investissement énergétique qu'elles représentent. Sa contribution à la réalisation des objectifs du développement durable local, national et international, à ses dimensions sociales, physiques ou environnementales du développement doit être reconnue.

Au cours des dernières décennies, les progrès de la recherche, de la coopération internationale et interdisciplinaire et les initiatives communautaires ont contribué à valoriser le patrimoine industriel et la collaboration entre les détenteurs, les intéressés et les experts pour sa conservation. Ce progrès a bénéficié d'un corpus de références et d'orientations internationales élaboré par l'ICOMOS (Conseil international des monuments et des sites) et de la mise en œuvre d'instruments internationaux dont la Convention du patrimoine mondial adoptée par I'UNESCO en 1972. En 2003, le Comité international pour la conservation du patrimoine industriel (TICCIH) adoptait la Charte de Nizhny Tagil, un premier texte de référence international pour aider à la protection et la conservation du patrimoine industriel.

Reconnaissant la nature particulière du patrimoine industriel et des enjeux et menaces qui l'affectent de par sa relation avec l'économie, les lois, la culture ou les questions environnementales actuelles, l'ICOMOS et le $\mathrm{TICCIH}$ étendent leur coopération en adoptant ces Principes conjoints et en encourageant leur application et leur dissémination pour aider à la connaissance, la protection, la conservation et la mise en valeur du patrimoine industriel comme partie du patrimoine des sociétés humaines à travers le monde.
1 Definition: The industrial heritage consists of sites, structures, complexes, areas and landscapes as well as the related machinery, objects or documents that provide evidence of past or ongoing industrial processes of production, the extraction of raw materials, their transformation into goods, and the related energy and transport infrastructures. Industrial heritage reflects the profound connection between the cultural and natural environment, as industrial processes - whether ancient or
1 Définition : Le patrimoine industriel comprend les sites, les constructions, les complexes, les territoires et les paysages ainsi que les équipements, les objets ou les documents qui témoignent des procédés industriels anciens ou courants de production par l'extraction et la transformation des matières premières ainsi que des infrastructures énergétiques ou de transport qui y sont associées. II exprime une relation étroite entre l'environnement culturel et naturel puisque les procédés industriels - anciens ou 
modern - depend on natural sources of raw materials, energy and transportation networks to produce and distribute products to broader markets. It includes both material assets immovable and movable -, and intangible dimensions such as technical know-how, the organisation of work and workers, and the complex social and cultural legacy that shaped the life of communities and brought major organizational changes to entire societies and the world in general.

2 Industrial heritage sites are very diversified in terms of their purpose, design and evolution over time. Many are representative of processes, technologies as well as regional or historical conditions while others constitute outstanding achievements of global influence. Others are complexes and multiple site operations or systems whose many components are interdependent, with different technologies and historical periods frequently present. The significance and value of industrial heritage is intrinsic to the structures or sites themselves, their material fabric, components, machinery and setting, expressed in the industrial landscape, in written documentation, and also in the intangible records contained in memories, arts and customs. modernes - dépendent de ressources naturelles, d'énergie et de voies de communication pour produire et distribuer des biens sur les marchés. Ce patrimoine comporte des dimensions immatérielles comme les savoirfaire techniques, l'organisation du travail et des travailleurs ou un héritage complexe de pratiques sociales et culturelles résultant de l'influence de l'industrie sur la vie des communautés et sur la mutation des sociétés et du monde en général.

2 La grande diversité des sites du patrimoine industriel découle de leurs fonctions, de leurs formes et de leur évolution. Beaucoup illustrent des procédés, des technologies ou des conditions régionales ou historiques. Certains constituent des réalisations exceptionnelles ou influentes. Les complexes industriels, les opérations réparties sur de multiples sites ou les systèmes regroupent des composantes souvent d'époques ou de technologies différentes.

L'intérêt du patrimoine industriel réside dans les constructions et les sites, dans leurs composantes matérielles et équipements, dans leur contexte et le paysage industriel qu'il forme, dans les documents ainsi que dans les dimensions immatérielles portées par la mémoire, les arts et les coutumes.

\section{I - Document and understand industrial heritage I - Étudier et comprendre les constructions, structures, sites, areas and landscapes and their sites, aires et paysages industriels et leur valeur values \\ patrimoniale}

3 Researching and documenting industrial structures, sites, landscapes and the related machinery, equipment, records or intangible aspects is essential to their identification, conservation, and the appreciation of their heritage significance and value. Human skills and knowledge involved in old industrial processes are a critically important resource in conservation and must be considered in the heritage evaluation process.

$4 \quad$ Researching and documenting industrial heritage sites and structures must address their historical, technological and socio-economical dimensions to provide an integrated base for conservation and management. It requires an interdisciplinary approach supported by interdisciplinary research and educational programmes to identify the significance of
3 L'étude et la documentation des constructions, des sites et paysages industriels ainsi que des machines, des équipements, des archives ou de leurs dimensions immatérielles est nécessaire à leur identification, leur conservation et l'appréciation de leur intérêt et de leur valeur patrimoniale. Les savoir-faire liés aux anciens procédés industriels sont d'une grande importance dans la conservation et doivent être pris en compte par les processus d'évaluation patrimoniale.

L'étude et la documentation des constructions et des sites du patrimoine industriel doivent examiner leurs dimensions historiques, technologiques et socio-économiques afin de fonder leur conservation et leur gestion sur une connaissance intégrée alimentée par une approche interdisciplinaire et par des recherches et des programmes éducatifs qui 
industrial heritage sites or structures. It should benefit from a diversity of sources of expertise and information including site surveys and recording, historical and archaeological investigation, material and landscape analysis, oral history and/or research in public, corporate or private archives. Research and preservation of documentary records, company archives, building plans, and specimens of industrial products should be encouraged. The evaluation and assessment of documents should be undertaken by an appropriate specialist in the industry to which they relate to determine their heritage significance. The participation of communities and other stakeholders is also an integral part of this exercise.

Thorough knowledge of the industrial and socio- 5 economic history of an area or country or their links to other parts of the world is necessary to understand the significance of industrial heritage sites or structures. Single industry context, typological or regional studies, with a comparative component, aimed at key industrial sectors or technologies are very useful in recognizing the heritage values inherent in individual structures, sites, areas or landscapes. They should be accessible and searchable by the public, scholars as well as managers.

\section{II - Ensure effective protection and conservation of the industrial heritage structures, sites, areas and landscapes}

6 Appropriate policies, legal and administrative measures need to be adopted and adequately implemented to protect and ensure the conservation of industrial heritage sites and structures, including their machinery and records. These measures have to address the close relation between the industrial heritage, industrial production and the economy, in particular with respect to rules for corporations and investments, trades or intellectual property such as patents, and standards applicable to active industrial operations.

7 Integrated inventories and lists of structures, sites, areas, landscapes their setting and associated objects, documents, drawings and archives or intangible heritage should be developed and used as part of these effective aident à énoncer leurs valeurs patrimoniales. Cette approche doit bénéficier de l'apport d'une diversité de sources d'expertise et d'information dont les études et relevés de site, les études historiques et archéologiques, les analyses matérielles ou paysagères ainsi que la consultation des archives publiques, d'entreprises ou privées. L'examen et la conservation des archives industrielles, des plans et d'échantillons ou d'exemples de production doivent être encouragés et leur évaluation devrait être menée par des spécialistes du type d'industrie auquel ils sont associés. La participation des citoyens, des communautés et d'autres intéressés est une partie intégrale de cette activité.

Une connaissance approfondie de l'histoire industrielle et socio-économique d'une ville, $d^{\prime}$ 'une région ou d'un pays ainsi que de leurs liens avec d'autres parties du monde est nécessaire pour comprendre l'intérêt patrimonial des constructions ou des sites industriels. Des études comparatives, typologiques ou régionales sur certains secteurs industriels ou certaines technologies sont utiles pour évaluer l'intérêt de constructions, de sites ou de paysages particuliers. Elles devraient être accessibles au public, aux chercheurs comme aux gestionnaires.

\section{II - Assurer la protection et la conservation efficaces des constructions, sites, aires et paysages du patrimoine industriel}

L'adoption et la mise en œuvre de politiques et de mesures légales et administratives adéquates sont nécessaires à la protection et à la conservation des constructions et des sites du patrimoine industriel y compris leurs équipements et documents. Ces mesures doivent tenir compte de la relation étroite entre le patrimoine industriel, la production et l'économie notamment quant aux règles sur les entreprises et sur les investissements, aux métiers, aux éléments de propriété intellectuelle comme les brevets et aux normes régissant les activités industrielles.

7 Des inventaires intégrés des constructions, sites, aires et paysages, leur contexte ainsi que des objets, documents, dessins, archives et patrimoine immatériel associés à l'industrialisation doivent être faits et utilisés 
management and conservation policies and protection measures. These should benefit from a legal recognition, adequate conservation and management to ensure that their significance, integrity and authenticity are maintained. In the case of industrial heritage identified through fortuitous discovery, temporary protection should be granted to allow time necessary for proper heritage documentation and research.

In the case of active industrial structures or sites 8 of heritage significance, it must be recognized that their continued use and function might carry some of their heritage significance and provide adequate conditions for their physical and economic sustainability as a living production or extraction facilities. Their specific technical characteristics and features need to be respected while implementing contemporary regulations such as building codes, environmental requirements or risk reduction strategies to address hazards of natural or human origin.

$9 \quad$ Protection measures should apply to buildings and their contents since completeness or functional integrity is especially important to the significance of industrial heritage structures and sites. Their heritage value may be greatly jeopardized or reduced if machinery or other significant components are removed, or if subsidiary elements which form part of a whole site are destroyed. Legal and administrative frameworks should be developed to enable authorities to respond quickly to the closure of operating industrial heritage sites and complexes to prevent removal or destruction of significant elements such as machinery, industrial objects or related records

\section{III - Conserve and maintain the industrial heritage structures, sites, areas and landscapes}

10 Appropriate original or alternative and adaptive use is the most frequent way and often the most sustainable way of ensuring the conservation of industrial heritage sites or structures. New uses should respect significant material, components and patterns of circulation and activity.

Specialist skills are necessary to ensure that the heritage significance is taken into account and respected in managing the sustainable use of these industrial heritage sites and structures. pour assurer l'efficacité des politiques et des protections. Les biens ainsi inventoriés devraient bénéficier d'une reconnaissance légale et de mesures qui en assurent le maintien de l'intérêt patrimonial, de l'intégrité et de l'authenticité. Dans le cas de découvertes fortuites, des protections temporaires devraient être accordées pour donner le temps nécessaire à une évaluation patrimoniale adéquate.

Pour les sites ou ensembles industriels actifs, la continuité de leur usage peut fonder en partie leur intérêt patrimonial et justifier le maintien de conditions adéquates pour leur conservation physique et leur viabilité économique à titre d'installations opérationnelles de production ou d'extraction. Leurs caractéristiques techniques propres doivent alors être respectées en appliquant les normes, exigences ou mesures contemporaines en matière de bâtiment, d'environnement ou de réduction des risques de catastrophes d'origine naturelle ou humaine.

9 Les mesures de protection devraient s'appliquer aux bâtiments et à leur contenu puisque l'intégrité fonctionnelle constitue un facteur majeur d'intérêt patrimonial pour les constructions et sites industriels. Cette valeur patrimoniale peut être lourdement menacée ou diminuée par l'enlèvement ou la démolition d'équipements ou de parties d'intérêt d'un ensemble. Les cadres légaux et administratifs doivent permettre aux autorités d'intervenir promptement quand des sites ou des complexes industriels patrimoniaux cessent leurs activités pour prévenir le démantèlement ou la destruction de machines, objets, documents ou autres éléments d'intérêt.

\section{III - Conserver les constructions, les sites, les aires et les paysages du patrimoine industriel}

Le maintien de l'usage d'origine ou d'un nouvel usage compatible est le mode de conservation le plus commun et souvent le plus viable pour les sites et les constructions industrielles. Les nouveaux usages devraient respecter les éléments d'intérêt du site comme les équipements, les circulations ou la distribution des activités. L'apport d'experts est nécessaire pour voir à ce que la valeur patrimoniale de constructions et de sites industriels soit 
Building codes, risk mitigation requirements, environmental or industrial regulations, and other standards should be implemented in an adapted way to take heritage dimensions into account when they are enforced through physical interventions.

11 Wherever possible, physical interventions should be reversible, and respect the age value and significant traces or marks. Changes should be documented. Reverting to a previous known state may be acceptable under exceptional circumstances for educational purposes, and must be based on thorough research and documentation. Dismantling and relocating are only acceptable in extraordinary cases when the destruction of the site is required by objectively proved overwhelming economic or social needs.

12 In case of prospective redundancy, decommissioning, and / or adaptation of industrial heritage sites or structures, the processes should be recorded including, for example, where components have to be demolished and machinery has to be removed. Their material form as well as their functioning and location as part of the industrial processes should be exhaustively documented. Oral and / or written stories of people connected with work processes should also be collected.

\section{IV - Present and communicate the heritage dimensions and values of industrial structures, sites, areas and landscapes to raise public and corporate awareness, and support training and research}

13 The industrial heritage is a source of learning which needs to be communicated in its multiple dimensions. It illustrates important aspects of local, national and international history and interactions over times and cultures. It demonstrates the inventive talents related to scientific and technological developments, as well as social and artistic movements. Public and corporate awareness and understanding for the industrial heritage are important means for its successful conservation. respectée dans la gestion de leur usage viable. L'application des codes de construction, des mesures de réduction des risques de sinistre, des réglementations environnementales ou industrielles et d'autres normes devrait être adaptée pour respecter les dimensions patrimoniales lorsqu'elle exige des interventions.

11 Les interventions physiques devraient être réversibles et respecter le caractère historique et les traces qui y contribuent. Les transformations devraient être documentées. Le rétablissement d'un état antérieur connu pourrait être recevable dans des cas exceptionnels à des fins éducatives ; il devrait reposer sur des recherches et une documentation complètes. Le démontage et le déplacement ne sont acceptables que lorsque des besoins impératifs économiques ou sociaux démontrés avec objectivité exigent la destruction du site.

12 En cas d'obsolescence de sites ou de constructions industriels d'intérêt patrimonial, les procédés devraient être documentés, notamment lorsque des composantes sont appelées à être démolies ou des machines retirées. Leur forme, leur fonctionnement et leur position et leur rôle dans le procédé industriel doivent être documentés exhaustivement. L'histoire orale ou les récits de personnes associées à ces procédés et le travail de l'industrie doivent aussi être colligés.

\section{IV - Présenter et communiquer les valeurs patrimoniales des constructions, sites, aires et paysages du patrimoine industriel pour sensibiliser le public et les entreprises et soutenir l'éducation et la recherche}

13 Le patrimoine industriel est une source d'enseignements qui doivent être partagés dans leurs multiples dimensions. II met en lumière des pans importants de l'histoire locale, nationale et internationale et les échanges de longue durée entre les cultures. II témoigne des talents et de l'ingéniosité associés au progrès des sciences et des techniques ainsi que de l'évolution de la société ou des arts. L'éveil d'une conscience du patrimoine industriel dans la population et dans les entreprises contribue au succès de sa conservation. 
14 Programmes and facilities such as visits of active industrial heritage sites and the presentation of their operations as well as the stories and intangible heritage associated with their history, machinery and industrial processes, industrial or city museums and interpretation centres, exhibitions, publications, websites, regional or trans-boundary itineraries should be developed and sustained as means to raise awareness and appreciation for the industrial heritage in the full richness of its meaning for contemporary societies. These should ideally be located at the heritage sites itself where the process of industrialisation has taken place and can be best communicated. Wherever possible, national and international institutions in the field of research and conservation of heritage should be empowered to use them as educational facilities for the general public and the professional communities.
14 La création et le maintien de programmes et d'équipements de mise en valeur du patrimoine industriel doivent être encouragés ; par exemple, les visites de sites en activité qui en exposent le fonctionnement et les récits ou le patrimoine immatériel associés à leur histoire, leurs machines ou leurs procédés, les musées de ville et les centres d'interprétation industriels, les expositions et les publications, le web ou des itinéraires régionaux ou transfrontaliers.

Préférablement, ces programmes et équipements de diffusion devraient être situés sur le site patrimonial où le processus $d^{\prime}$ industrialisation s'est déroulé et où il peut être le mieux présenté. Autant que possible, les organisations nationales et internationales dans les domaines de l'étude et de la conservation du patrimoine devraient être en mesure d'utiliser ces sites à des fins éducatives pour le grand public et les milieux spécialisés. 


\section{APPENDIX C}

\section{World Heritage List: Rideau Canal}

Description: The Rideau Canal, a monumental early 19th-century construction covering $202 \mathrm{~km}$ of the Rideau and Cataraqui rivers from Ottawa south to Kingston Harbour on Lake Ontario, was built primarily for strategic military purposes at a time when Great Britain and the United States vied for control of the region. The site, one of the first canals to be designed specifically for steam-powered vessels, also features an ensemble of fortifications. It is the best-preserved example of a slackwater canal in North America, demonstrating the use of this European technology on a large scale. It is the only canal dating from the great North American canal-building era of the early 19th century to remain operational along its original line with most of its structures intact.

Outstanding Universal Value: The Rideau Canal is a large strategic canal constructed for military purposes which played a crucial contributory role in allowing British forces to defend the colony of Canada against the United States of America, leading to the development of two distinct political and cultural entities in the north of the American continent, which can be seen as a significant stage in human history.

Criterion (i): The Rideau Canal remains the best preserved example of a slackwater canal in North America demonstrating the use of European slackwater technology in North America on a large scale. It is the only canal dating from the great North American canalbuilding era of the early 19th century that remains operational along its original line with most of its original structures intact.

Criterion (iv): The Rideau Canal is an extensive, well preserved and significant example of a canal which was used for a military purpose linked to a significant stage in human history - that of the fight to control the north of the American continent.

The nominated property includes all the main elements of the original canal together with relevant later changes in the shape of watercourses, dams, bridges, fortifications, lock stations and related archaeological resources. The original plan of the canal, as well as the form of the channels, has remained intact. The Rideau Canal has fulfilled its original dynamic function as an operating waterway without 
interruption since its construction. Most of its lock gates and sluice valves are still operated by hand-powered winches.

All the elements of the nominated area (canal, associated buildings and forts) are protected as national historic sites under the Historic Sites and Monuments Act 1952-3. A buffer zone has been established. Repairs and conservation of the locks, dams, canal walls and banks are carried out directly under the control of Parks Canada. Each year one third of the canal's assets are thoroughly inspected by engineers. A complete inventory thus exists of the state of conservation of all parts of the property. A Management Plan exists for the canal (completed in 1996 and updated in 2005), and plans are nearing completion for Fort Henry and the Kingston fortifications. The Canal Plan is underpinned by the Historic Canals Regulations which provide an enforcement mechanism for any activities that might impact on the cultural values of the monument. 


\section{Appendix D}

\section{Canadian Register of Historic Places}

Statements of significance and designation information prepared

in 1988 are included for both the West Mill and East Mill at 34 Beckwith

Street South, Smiths Falls, Ontario. 


\section{West Mill}

34 Beckwith Street South, Smiths Falls, Ontario, Canada

\section{Formally Recognized: 1988/12/08}

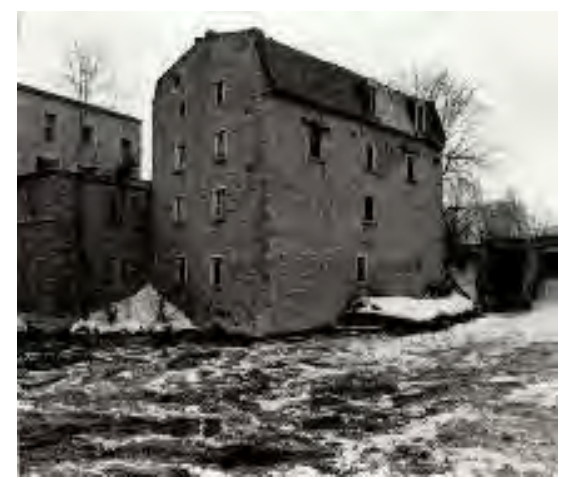

Side view

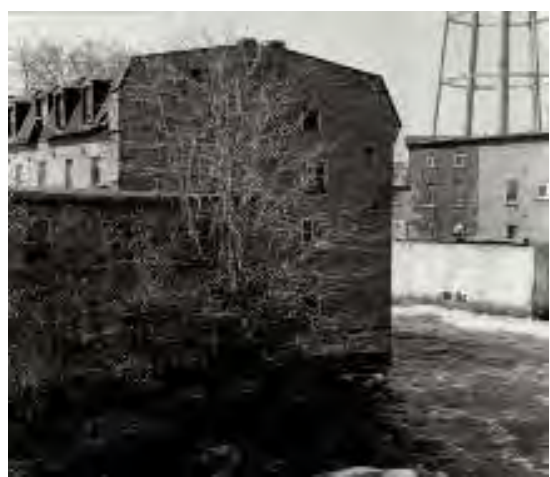

Side view

\section{OTHER NAME(S)}

West Mill

Wood's Mill Complex, West Mill

\section{LINKS AND DOCUMENTS}

\section{FHBRO Heritage Character Statement}

\section{CONSTRUCTION DATE(S)}

$1852 / 01 / 01$ to $1855 / 01 / 01$

\section{LISTED ON THE CANADIAN REGISTER: 2008/10/23}

\section{STATEMENT OF SIGNIFICANCE}

\section{DESCRIPTION OF HISTORIC PLACE}

The West Mill is part of the Wood's Mill complex located at Smiths Falls. The complex itself sits at the northern end of Ward's Island adjacent to the waste weir channel of the Rideau Waterway at Smiths Falls. The large stone building features a mansard roof, gable-roofed dormers and a five bay façade with regularly placed windows. The central main entrance is flanked to one side by the large doors of a loading bay. The designation is confined to the footprint of the building.

\section{HERITAGE VALUE}

The West Mill is a Recognized Federal Heritage Building because of its historical associations, and its architectural and environmental values. 


\section{Historical Value}

The West Mill, as part of a mid and late-nineteenth-century industrial complex, is closely associated with the development of the grain milling industry in eastern Ontario. The complex also shows the evolution and adaptation of grain milling from a local service industry, to one based on the processing of imported western grain and the export of the product. The industrial development of the Smiths Falls area is notable where the shift from reliance on the canal to a reliance on the railway was evident. The West Mill is associated with A.R. Ward, one of the first permanent settlers of the area and founder of the milling complex, and A. Wood, an important local entrepreneur who operated several industrial firms in the area.

Architectural Value

Valued for its good aesthetics, the West Mill exhibits domestic vernacular form, scale and proportions. The industrial character of the building is expressed through the evenly spaced fenestration pattern and the elements relating to its function including the double loading doors and the functional interior spaces. Good craftsmanship and materials can be seen in the stonework of the exterior walls.

Environmental Value

The West Mill reinforces the commercial character of its industrial complex and streetscape setting at Smiths Falls, and is a familiar landmark in the region.

Sources: James De Jonge, Wood's Mill Complex, 34 Beckwith Street South, Smiths Falls, Ontario, Federal Heritage Buildings Review Office, Building Report 88-044; Wood's Mill Complex, 34 Beckwith Street South, Smiths Falls, Ontario, Heritage Character Statement 88-044.

\section{CHARACTER-DEFINING ELEMENTS}

The character-defining elements of the West Mill should be respected.

Its good aesthetic, functional design and good quality craftsmanship and materials, for example:

- the two-and-a-half-storey massing;

- the exterior walls of stone;

- the mansard roof and the gable roofed dormers;

- the regular placement of the doors, windows and the loading bay doors;

- the interior configuration.

The manner in which the West Mill reinforces the commercial character of its industrial complex and streetscape setting at Smiths Falls, and is a familiar landmark in the region, as evidenced by: - its overall scale, design and materials, which contribute to its commercial streetscape surroundings and complement the edge of the industrial complex;

- its visibility due to its location within the streetscape, at the edge of the commercial core and adjacent to a water channel.

\section{RECOGNITION}

\section{JURISDICTION}

Federal 


\author{
RECOGNITION AUTHORITY \\ Government of Canada \\ RECOGNITION STATUTE \\ Treasury Board Heritage Buildings Policy \\ RECOGNITION TYPE \\ Recognized Federal Heritage Building \\ RECOGNITION DATE \\ $1988 / 12 / 08$ \\ HISTORICAL INFORMATION \\ SIGNIFICANT DATE(S) \\ $\mathrm{n} / \mathrm{a}$ \\ THEME - CATEGORY AND TYPE \\ FUNCTION - CATEGORY AND TYPE \\ CURRENT \\ HISTORIC \\ Industry \\ Food and Beverage Manufacturing Facility
}

ARCHITECT / DESIGNER

$\mathrm{n} / \mathrm{a}$

BUILDER

$\mathrm{n} / \mathrm{a}$

ADDITIONAL INFORMATION

LOCATION OF SUPPORTING DOCUMENTATION

National Historic Sites Directorate, Documentation Centre, 5th Floor, Room 89, 25 Eddy Street,

Gatineau, Quebec

CROSS-REFERENCE TO COLLECTION

FED/PROV/TERR IDENTIFIER

3265

STATUS

Published

RELATED PLACES 


\section{East Mill}

The East Mill is part of the Wood's Mill Complex located at Smiths Falls.

The complex itself sits on the northern extremity of Ward's Island adjacent to the waste weir channel of...

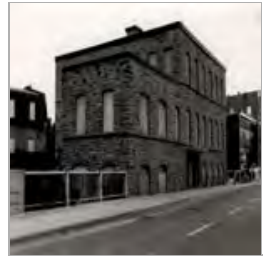

\section{NEARBY PLACES}

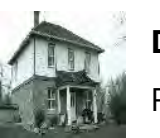

Defensible Lockmaster's House

Rideau Canal National Historic Site of Canada / Lieu historique national du Canada du Canal-Rideau, Ontario

The Defensible Lockmaster's House overlooks the Rideau Canal and stands close to the lock at...

\section{Defensible Lockmaster's House}

Rideau Canal National Historic Site of Canada / Lieu historique national du Canada du Canal-Rideau, Ontario 


\section{East Mill}

34 Beckwith Street South, Smiths Falls, Ontario, Canada

\section{Formally Recognized: 1988/12/08}

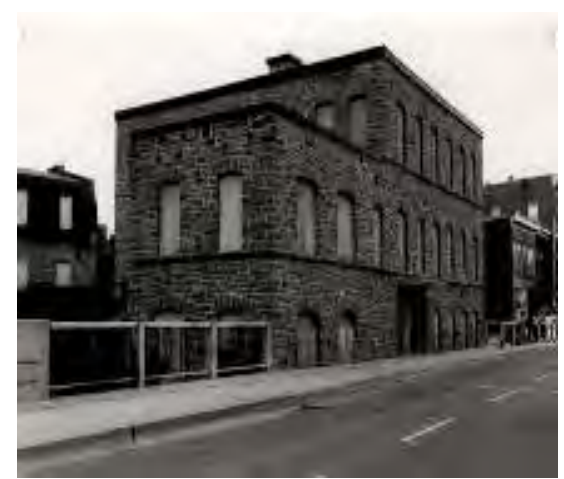

Side view

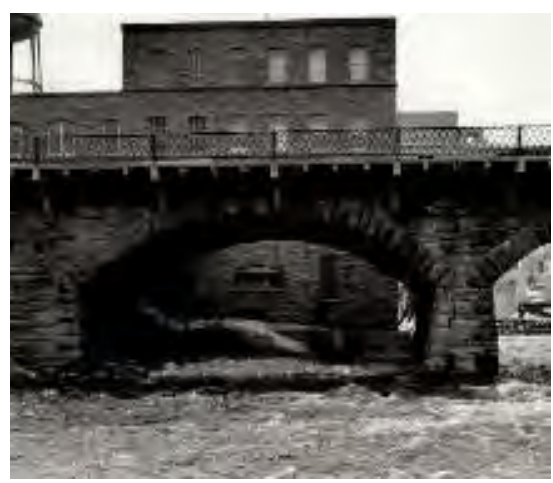

East elevation

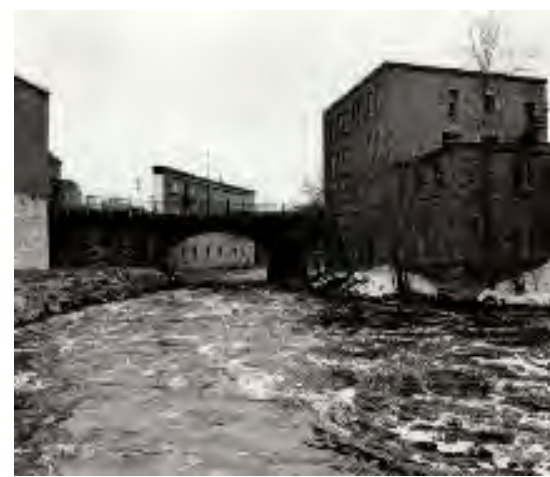

Side view

\section{OTHER NAME(S)}

East Mill

Wood's Mill Complex, East Mill

\section{LINKS AND DOCUMENTS}

\section{FHBRO Heritage Character Statement}

\section{CONSTRUCTION DATE(S)}

$1890 / 01 / 01$ to $1892 / 01 / 01$

\section{LISTED ON THE CANADIAN REGISTER: 2008/10/22}

\section{STATEMENT OF SIGNIFICANCE}

\section{DESCRIPTION OF HISTORIC PLACE}

The East Mill is part of the Wood's Mill Complex located at Smiths Falls. The complex itself sits on the northern extremity of Ward's Island adjacent to the waste weir channel of the Rideau Waterway at Smiths Falls. The large, four-storey, stone building has a flat roof, unornamented exterior walls and rows of regular windows. A smaller, two-storey office wing abuts the south façade. The designation is confined to the footprint of the building.

\section{HERITAGE VALUE}

The East Mill is a Recognized Federal Heritage Building because of its historical associations, and its architectural and environmental values. 
Historical Value

The East Mill, as part of a late-nineteenth-century industrial complex, is closely associated with the development of the grain milling industry in eastern Ontario. The East Mill and Wood's Mill Complex illustrate the evolution and adaptation of grain milling from a local service industry, to one based on the processing of imported western grain and the export of the product. The industrial development of the Smiths Falls area is notable where the shift from reliance on the canal to a reliance on the railway was evident. The East Mill is associated with A.R. Ward, one of the first permanent settlers of the area and founder of the milling complex, and A. Wood, an important local entrepreneur who operated several industrial firms in the area.

Architectural Value

Valued for its good aesthetics, the East Mill exhibits a distinctly industrial character as defined by its evenly spaced fenestration pattern and its functional, flexible interior spaces. The unornamented appearance reflects the utilitarian purpose of the building. Very good craftsmanship and materials can be seen in the stone walls and in the heavy timber frame substructure.

Environmental Value

The East Mill reinforces the commercial character of its industrial complex and streetscape setting at Smiths Falls, and is a familiar landmark in the region.

Sources: James De Jonge, Wood's Mill Complex, 34 Beckwith Street South, Smiths Falls, Ontario, Federal Heritage Buildings Review Office, Building Report 88-044; Wood's Mill Complex, 34 Beckwith Street South, Smiths Falls, Ontario, Heritage Character Statement 88-044.

\section{CHARACTER-DEFINING ELEMENTS}

The character-defining elements of the East Mill should be respected.

Its good aesthetic and good quality craftsmanship and materials, for example:

- the four-storey massing, the two-storey adjoining addition;

- the exterior walls of uncoursed limestone blocks;

- the heavy timber frame substructure;

- the regular placement of the doors and evenly spaced windows;

- the interior configuration.

The manner in which the East Mill reinforces the commercial character of its industrial complex and streetscape setting, and is a familiar landmark in the region, as evidenced by:

- its overall scale, design and materials, which contribute to its commercial streetscape surroundings and complement the industrial complex;

- its visibility due to its location within the streetscape at the edge of the commercial core and adjacent to a bridge and water channel.

\section{RECOGNITION}

\section{JURISDICTION}

Federal 


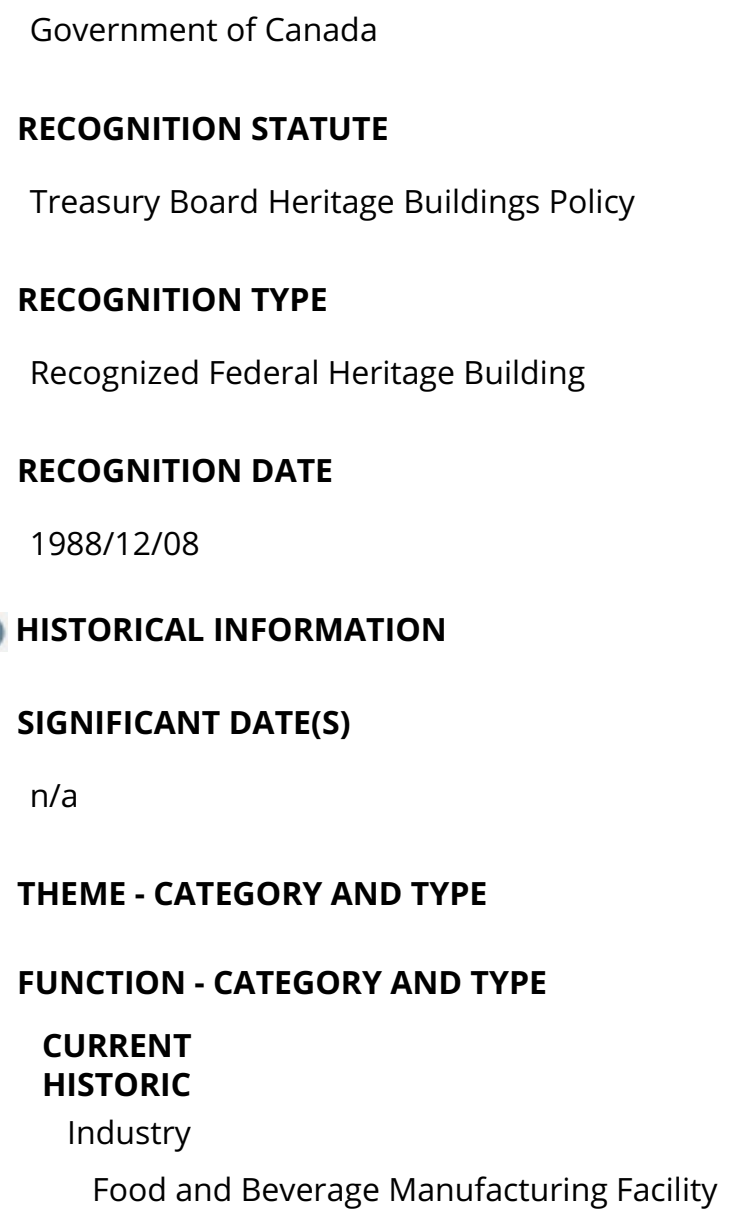




\section{West Mill}

The West Mill is part of the Wood's Mill complex located at Smiths Falls.

The complex itself sits at the northern end of Ward's Island adjacent to the waste weir channel of the...

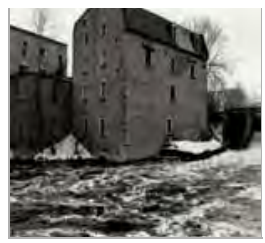

\section{NEARBY PLACES}

Smiths Falls Bascule Bridge National Historic Site of Canad Abbot Street, Smiths Falls, Ontario

Smiths Falls Bascule Bridge National Historic Site of Canada is

\section{Heritage House Museum}

11, Old Slys Road, Smiths Falls, Ontario

The Heritage House Museum, also known as the Ward House, is a two-and-a-half-storey Georgian... 
The purpose for doing this work is to better understand the topography of the landscape and how it was modified to accommodate the locks and power the mills. Additionally, using the equipment and processing the data is an excellent way to develop surveying skills.

First, the Total Station (TS06) was used to create a network of control points. Then the Faro Focus laser scanner collected coordinate data consisting of millions of points to represent the external surfaces of the structures and landscape. A point cloud of the roofs was generated from aerial photos shot by the drone using photogrammetry. The individual point clouds from the laser scanner and photogrammetry were registered the control points to create one large point cloud of the whole landscape.

Some notable challenges include: ongoing construction on the Beckwith Street bridge adjacent to the mills; limited accessibility to certain areas of the site due to the river and Water Works Building; poor placement of targets; glitches with survey equipment and software; overall lack of experience. Not surprisingly, the accuracy of the data varies considerably. The interior of the West Mill and the south courtyard of the complex (by the main entrance) were fairly accurate (approximately 8-15 mm) while the south façade is accurate to about $20 \mathrm{~cm}$ and data of the north and west facades obtained from behind the Water Works Building could not be accurately registered with the rest of the data. Nevertheless, the resulting point cloud is an excellent tool for visualization.

To make the site model, the point cloud was imported into Rhinoceros where it was converted into a mesh model. The mesh was scaled to 1:350 and simplified to include only the topography and building footprints. Any proposed changes and missing elements of the landscape were modeled in Rhino. This was then carved in plywood using a CNC machine. The buildings were carved out of poplar using a combination of machinery and hand tools in the wood shop. A dark stain and polyurethane gloss was applied to the current waterways while a dark stain and matte finish was used to indicate the historic path of the Rideau River. 

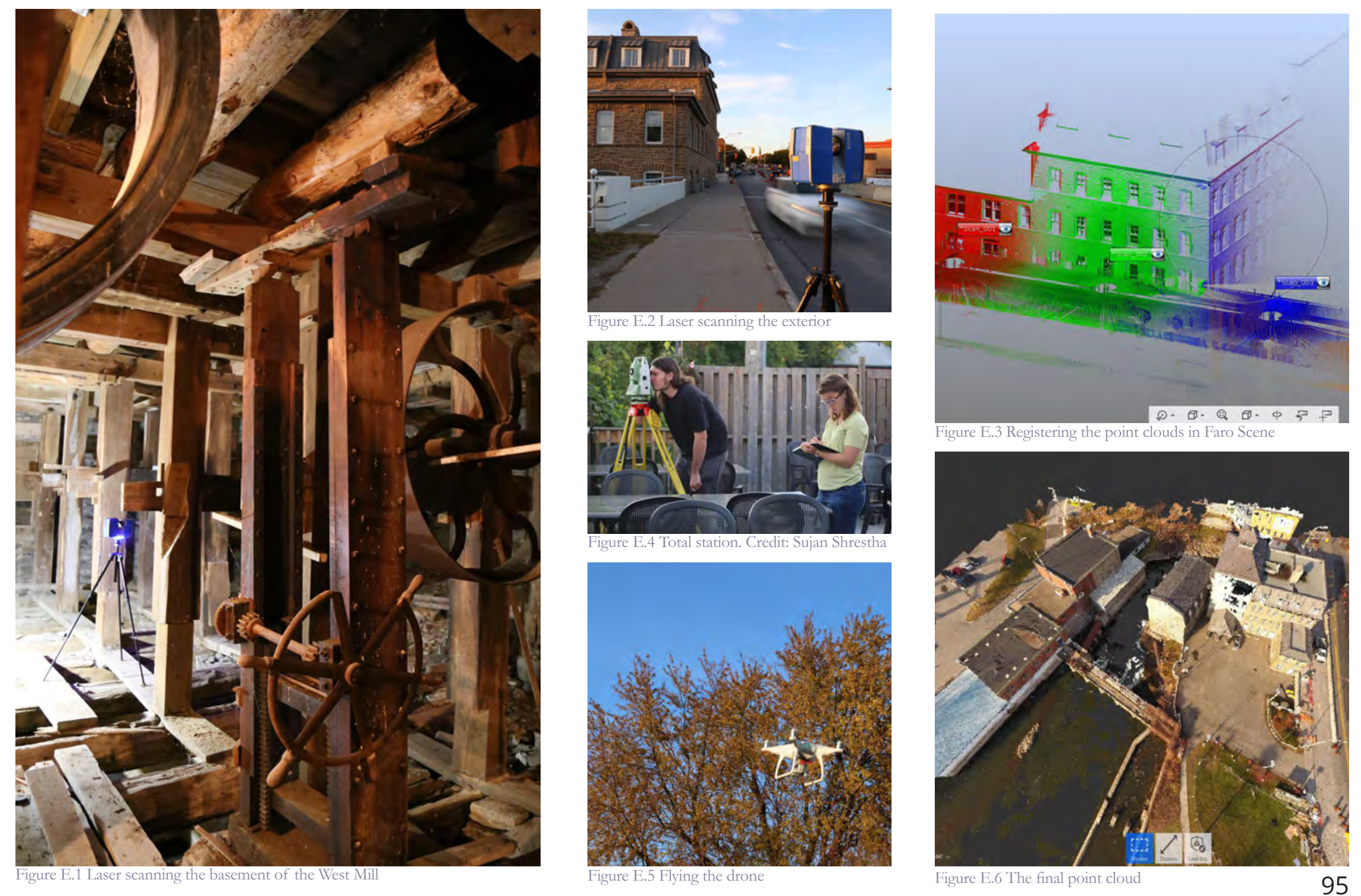

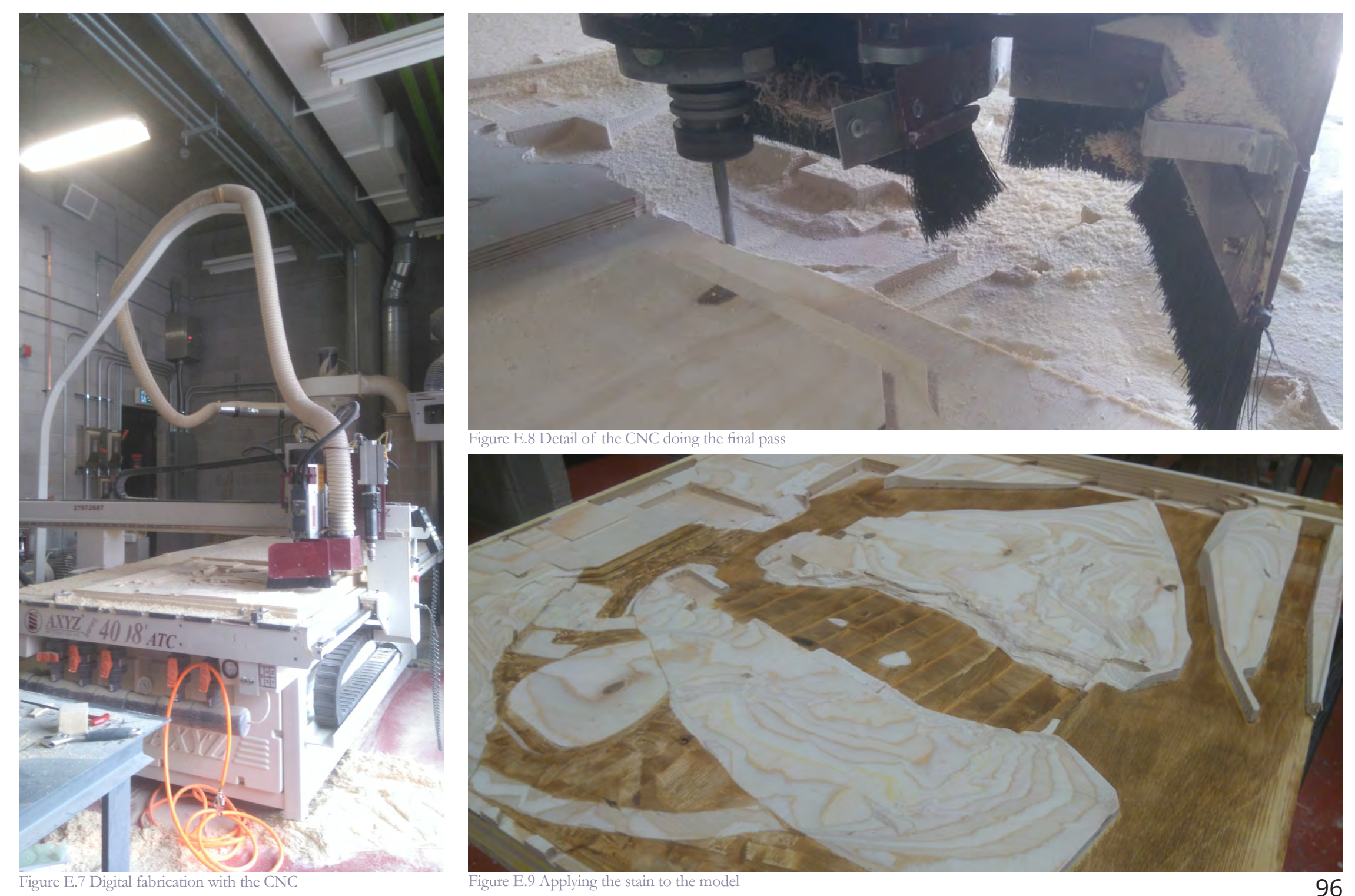


\section{Building Envelope Analysis}

In many ways, 19th century buildings are inherently sustainable with regard to lifecycle impacts (embodied energy, durability, etc.) and use of passive energy flows, but this may not be enough to meet the Architecture 2030 goals to limit climate change. Heritage buildings are currently exempt from meeting today's high standards in energy efficiency, but looking forward, those that survive will be the ones that can adapt.

Whether or not it is ok to insulate masonry buildings from the interior is a subject of much debate and misunderstanding. It is generally agreed that lower risk interventions be implemented first, such as: good maintenance, restoring and enhancing inherently sustainable features, adding attic insulation, controlling air tightness and ventilation, storm windows, etc. Although adding insulation does change heat flow through the building envelope, freeze-thaw damage is nearly always the result of an existing exposure problem. However, it may be possible to achieve significant energy savings by insulating masonry structures which are well maintained, use high quality materials and are air tight.

The process of determining whether or not interior insulation 1 Bill Rose, personal communication, February 18, 2017 is appropriate for the Wood's Mill Complex is as follows:

1) monitor existing conditions with special attention to the basement, given the higher humidity and proximity to the river.

2) repair and maintain the building to reduce exposure and moisture content of masonry

3) improve air tightness while maintaining vapour permeability - repointing masonry, lime plaster finish, spray foam in corners, gaps around windows, etc.

4) hygrothermal analysis such as (WUFI) to determine which type and how much (if any) insulation should be used, where it should be used and how to treat embedded beams and tie rods.

5) cost-benefit analysis and lifecycle analysis to see if it makes sense to do this

6) install insulation and monitor performance

7) share results ${ }^{1}$ 
ApPendix G

\section{Community Survey}

This survey was conducted by the author in accordance with Carleton University Research Ethics Board. 


\section{Default Report}

Building Resilient Communities Survey

April 2nd 2017, 1:04 am EDT

Q2 - What is your gender?

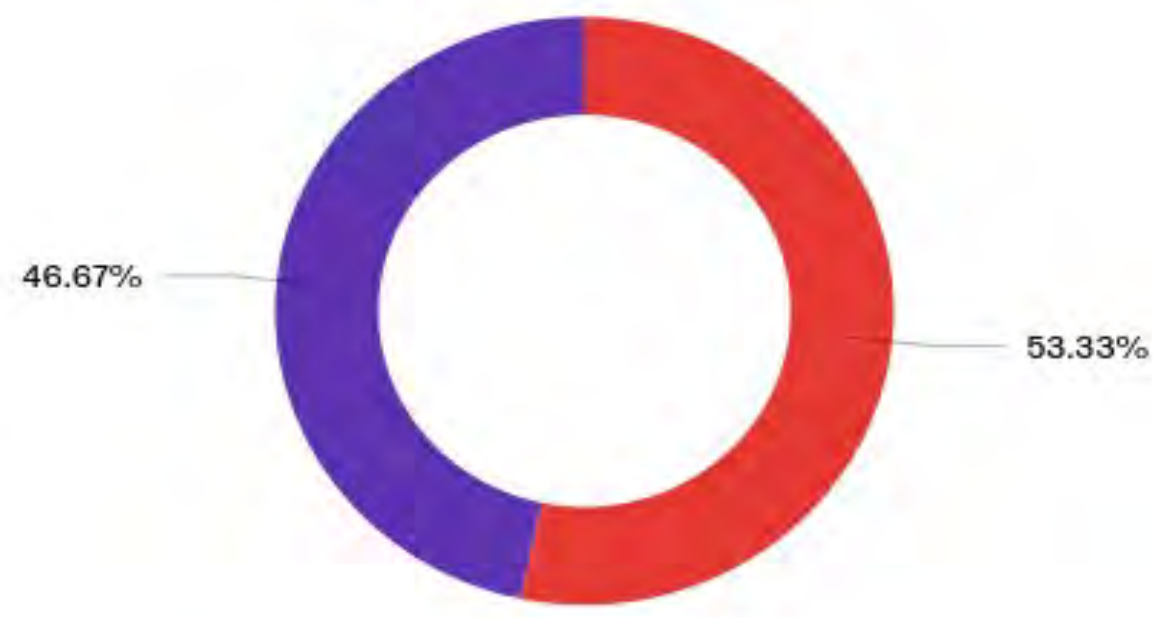

\begin{tabular}{r|r|r|r|}
\hline$\#$ & Answer & $\%$ & Count \\
\hline 1 & male & $53.33 \%$ & 8 \\
\hline 2 & female & $46.67 \%$ & 7 \\
\hline 3 & prefer not to answer & $0.00 \%$ & 0 \\
\hline & Total & $100 \%$ & 15 \\
\hline
\end{tabular}


Q3 - Into which age range do you fall?

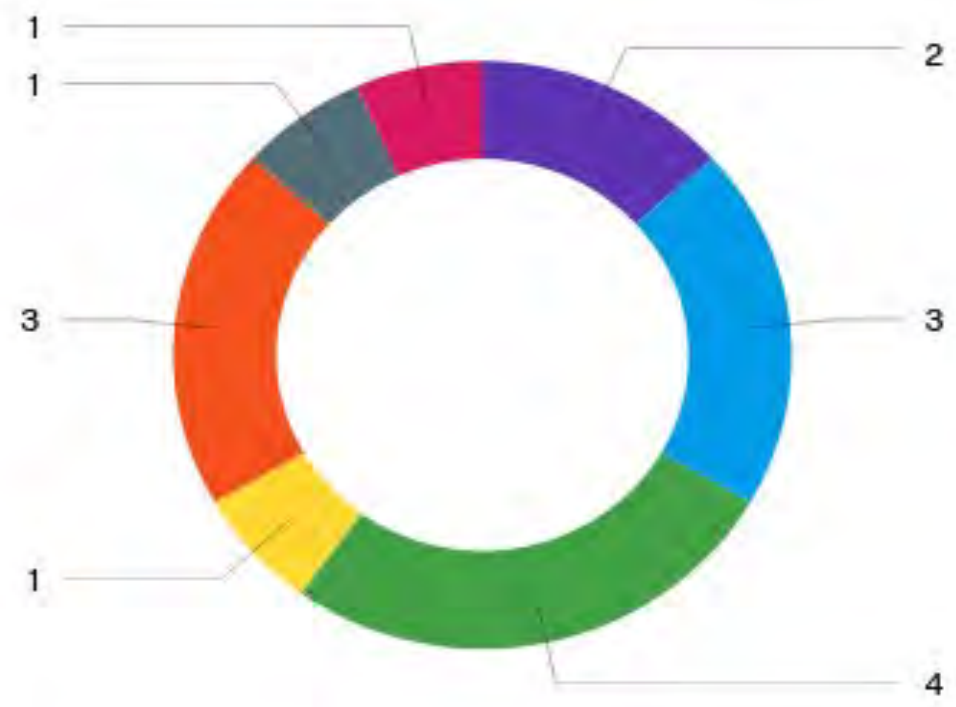

16-19 $\square 20-24 \square 25-34 \square 35-44 \square 45-54 \square 55-64 \square 65^{+}$

prefer not to answer

\begin{tabular}{r|r|r|r|}
\hline$\#$ & Answer & $\%$ & Count \\
\hline 1 & $16-19$ & $0.00 \%$ & 0 \\
\hline 2 & $20-24$ & $13.33 \%$ & 2 \\
\hline 3 & $25-34$ & $20.00 \%$ & 3 \\
\hline 4 & $35-44$ & $26.67 \%$ & 4 \\
\hline 5 & $45-54$ & $6.67 \%$ & 1 \\
\hline 6 & $55-64$ & $20.00 \%$ & 3 \\
\hline 7 & $65+$ & $6.67 \%$ & 1 \\
\hline 8 & prefer not to answer & $6.67 \%$ & 1 \\
\hline & Total & $100 \%$ & 15 \\
\hline
\end{tabular}




\section{Q4 - Where is your permanent residence?}

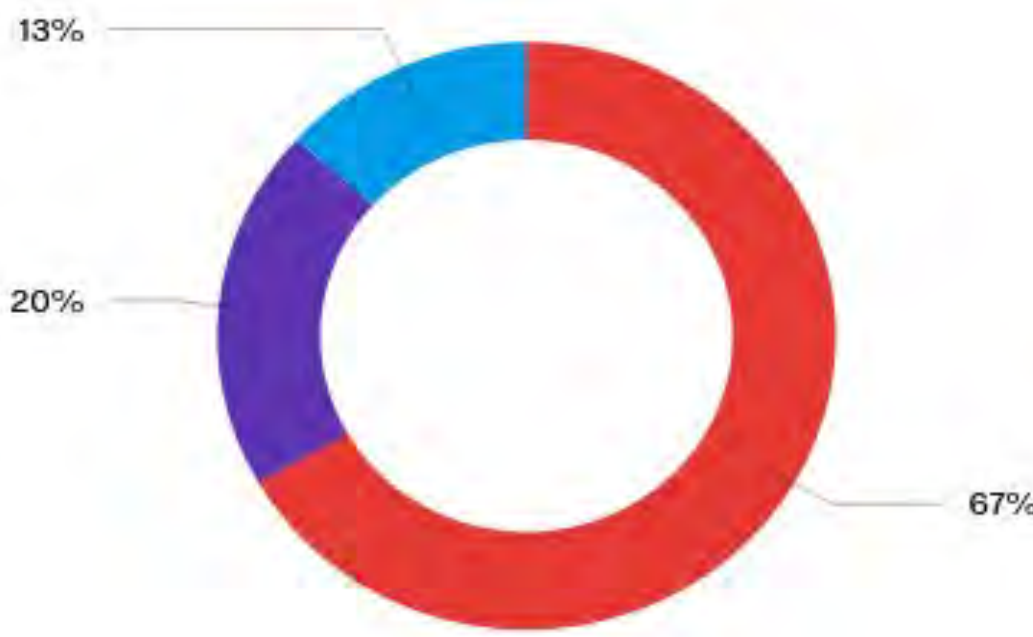

local (within $40 \mathrm{~km}$ of Smiths Falls)

surrounding area (41-100 km from Smiths Falls, including Kingston and the National Capital Region)

visitors (101+ km from Smiths Falls

\begin{tabular}{r|r|r|r|}
\hline$\#$ & Answer & $\%$ & Count \\
\hline 1 & local (within $40 \mathrm{~km}$ of Smiths Falls) & $66.67 \%$ & 10 \\
\hline 2 & surrounding area (41-100 km from Smiths Falls, including Kingston and the National Capital & $20.00 \%$ & 3 \\
\hline 3 & Region) & visitors (101+km from Smiths Falls & $13.33 \%$ \\
\hline & Total & $100 \%$ & 15 \\
\hline
\end{tabular}


Q5 - How familiar are you with the Wood's Mill Complex (comprised of the East Mill, West Mill and Rideau Canal Museum) in Smiths Falls at 34 Beckwith Street South? (see image below)

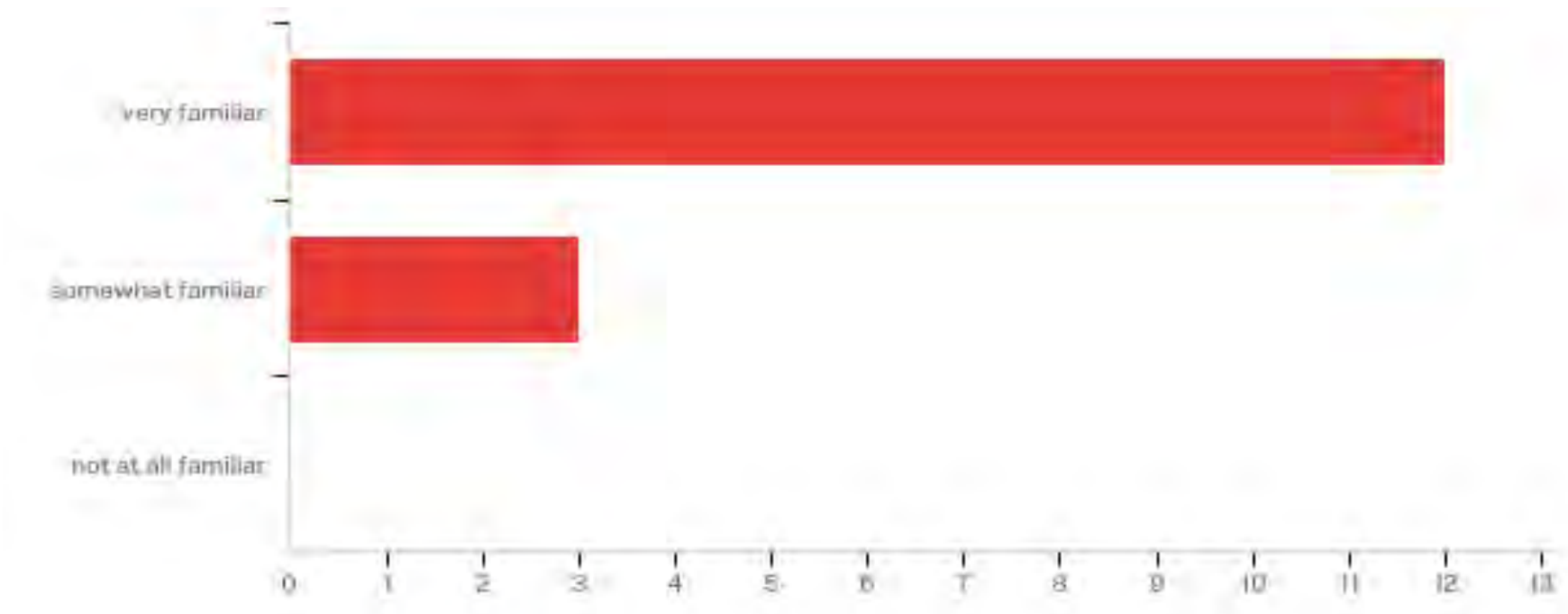

\begin{tabular}{r|r|r|r|}
\hline$\#$ & Answer & $\%$ & Count \\
\hline 1 & very familiar & $80.00 \%$ & 12 \\
\hline 2 & somewhat familiar & $20.00 \%$ & 3 \\
\hline 3 & not at all familiar & $0.00 \%$ & 0 \\
\hline & Total & $100 \%$ & 15 \\
\hline
\end{tabular}


Q6 - State if you are interested in seeing the Wood's Mill Complex developed into each of the following options (select all that apply):

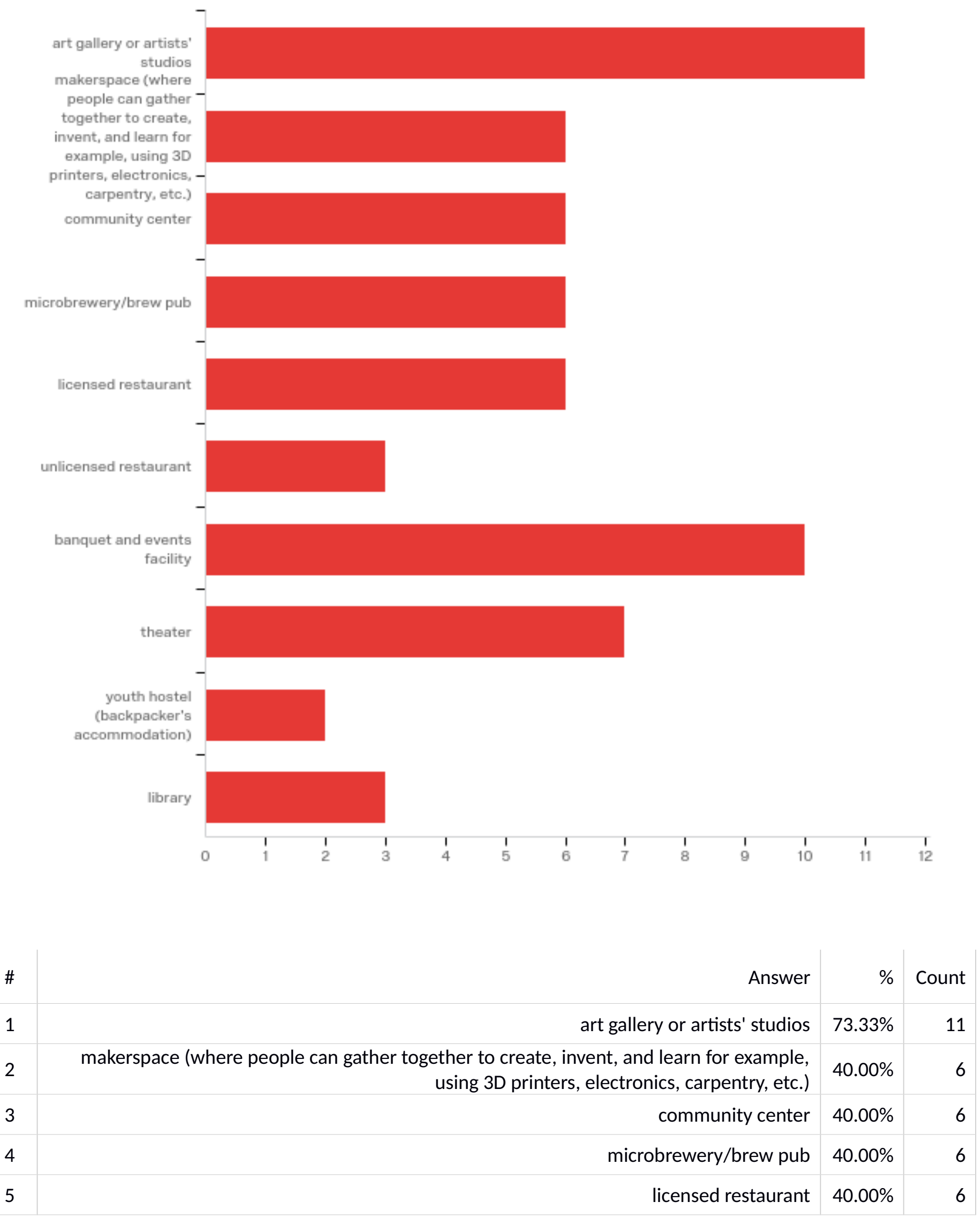




\begin{tabular}{|r|r|r|r|}
\hline 6 & unlicensed restaurant & $20.00 \%$ & 3 \\
\hline 7 & banquet and events facility & $66.67 \%$ & 10 \\
\hline 8 & theater & $46.67 \%$ & 7 \\
\hline 9 & youth hostel (backpacker's accommodation) & $13.33 \%$ & 2 \\
\hline 10 & library & $20.00 \%$ & 3 \\
\hline & Total & $100 \%$ & 15 \\
\hline
\end{tabular}


Q7 - Do you have any suggestions for developing this property that are not listed above?

Do you have any suggestions for developing this property that are not liste...

If condos go in the other buildings, it would make a nice common area for the residents of the complex

Gaming center - Gathering for those who want to game with small fitness classes for health and wellness. 


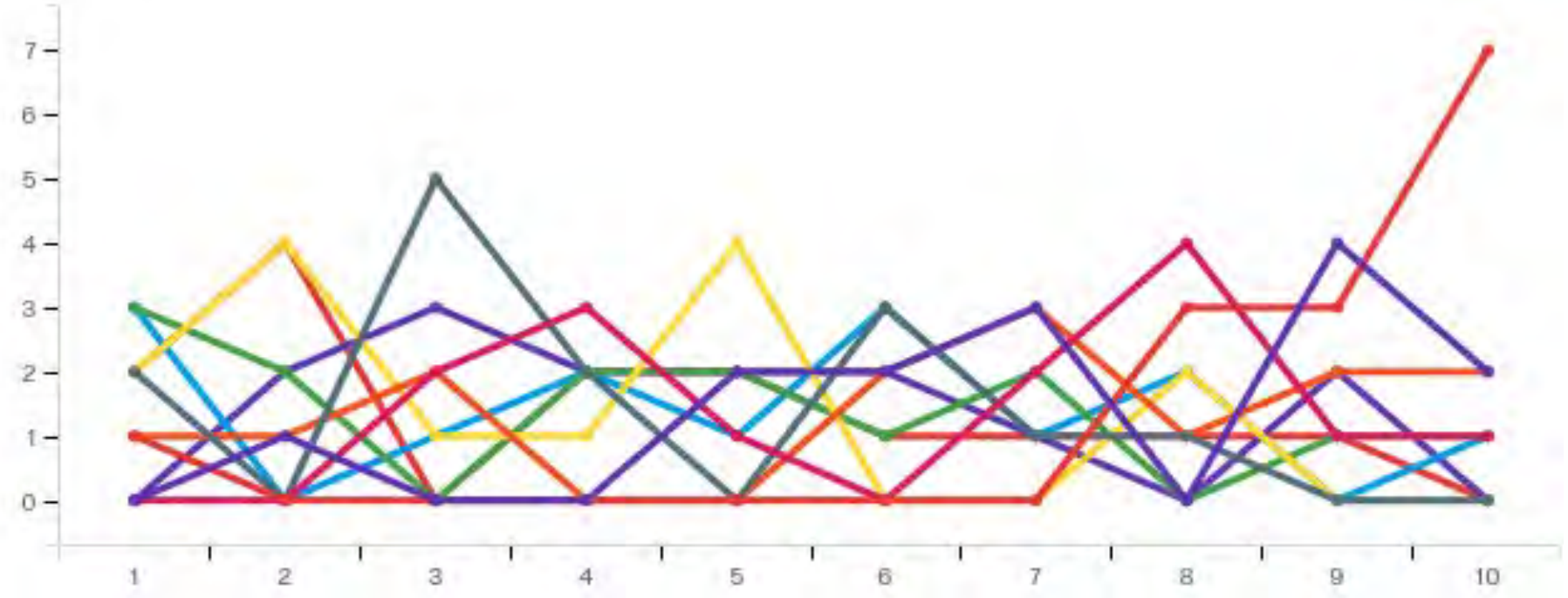

art gallery or artists' studios makerspace $\quad$ community center $\mathbf{m i c r o b r e w e r y / b r e w ~ p u b ~}$ Iicensed restaurant unlicensed restaurant $\quad$ banquet and events facility $\mathbf{E}$ theater youth hostel (backpacker's accommodation) library

\begin{tabular}{|c|c|c|c|c|c|c|c|c|c|c|c|c|c|c|c|c|c|c|c|c|c|c|}
\hline \# & $\begin{array}{l}\text { Qu } \\
\text { esti } \\
\text { on }\end{array}$ & 1 & & 2 & & 3 & & 4 & & 5 & & 6 & & 7 & & 8 & & 9 & & 10 & & $\begin{array}{r}\text { Tot } \\
\text { al }\end{array}$ \\
\hline 1 & $\begin{array}{r}\text { art } \\
\text { gall } \\
\text { ery } \\
\text { or } \\
\text { arti } \\
\text { sts' } \\
\text { stu } \\
\text { dio } \\
\mathrm{s}\end{array}$ & $\begin{array}{r}14 \\
.2 \\
9 \\
\%\end{array}$ & 2 & $\begin{array}{r}28 . \\
57 \\
\%\end{array}$ & 4 & $\begin{array}{l}0.0 \\
0 \%\end{array}$ & 0 & $\begin{array}{r}14 . \\
29 \\
\%\end{array}$ & 2 & $\begin{array}{r}14 . \\
29 \\
\%\end{array}$ & 2 & $\begin{array}{l}7.1 \\
4 \%\end{array}$ & 1 & $\begin{array}{l}7.1 \\
4 \%\end{array}$ & 1 & $\begin{array}{l}7.1 \\
4 \%\end{array}$ & 1 & $\begin{array}{l}7.1 \\
4 \%\end{array}$ & 1 & $\begin{array}{l}0.0 \\
0 \%\end{array}$ & 0 & 14 \\
\hline 2 & $\begin{array}{l}\text { ma } \\
\text { ker } \\
\text { spa } \\
\text { ce }\end{array}$ & $\begin{array}{c}0 . \\
00 \\
\%\end{array}$ & 0 & $\begin{array}{r}14 . \\
29 \\
\%\end{array}$ & 2 & $\begin{array}{r}21 . \\
43 \\
\%\end{array}$ & 3 & $\begin{array}{r}14 . \\
29 \\
\%\end{array}$ & 2 & $\begin{array}{r}14 . \\
29 \\
\%\end{array}$ & 2 & $\begin{array}{r}14 . \\
29 \\
\%\end{array}$ & 2 & $\begin{array}{l}7.1 \\
4 \%\end{array}$ & 1 & $\begin{array}{l}0.0 \\
0 \%\end{array}$ & 0 & $\begin{array}{r}14 . \\
29 \\
\%\end{array}$ & 2 & $\begin{array}{l}0.0 \\
0 \%\end{array}$ & 0 & 14 \\
\hline 3 & $\begin{array}{c}\text { co } \\
\text { m } \\
\text { mu } \\
\text { nity } \\
\text { cen } \\
\text { ter }\end{array}$ & $\begin{array}{r}21 \\
.4 \\
3 \\
\%\end{array}$ & 3 & $\begin{array}{l}0.0 \\
0 \%\end{array}$ & 0 & $\begin{array}{l}7.1 \\
4 \%\end{array}$ & 1 & $\begin{array}{r}14 . \\
29 \\
\%\end{array}$ & 2 & $\begin{array}{l}7.1 \\
4 \%\end{array}$ & 1 & $\begin{array}{r}21 . \\
43 \\
\%\end{array}$ & 3 & $\begin{array}{l}7.1 \\
4 \%\end{array}$ & 1 & $\begin{array}{r}14 . \\
29 \\
\%\end{array}$ & 2 & $\begin{array}{l}0.0 \\
0 \%\end{array}$ & 0 & $\begin{array}{l}7.1 \\
4 \%\end{array}$ & 1 & 14 \\
\hline 4 & $\begin{array}{l}\text { mic } \\
\text { rob } \\
\text { rew } \\
\text { ery }\end{array}$ & $\begin{array}{r}21 \\
.4 \\
3 \\
\%\end{array}$ & 3 & $\begin{array}{r}14 . \\
29 \\
\%\end{array}$ & 2 & $\begin{array}{l}0.0 \\
0 \%\end{array}$ & 0 & $\begin{array}{r}14 . \\
29 \\
\%\end{array}$ & 2 & $\begin{array}{r}14 . \\
29 \\
\%\end{array}$ & 2 & $\begin{array}{l}7.1 \\
4 \%\end{array}$ & 1 & $\begin{array}{r}14 . \\
29 \\
\%\end{array}$ & 2 & $\begin{array}{l}0.0 \\
0 \%\end{array}$ & 0 & $\begin{array}{l}7.1 \\
4 \%\end{array}$ & 1 & $\begin{array}{l}7.1 \\
4 \%\end{array}$ & 1 & 14 \\
\hline
\end{tabular}




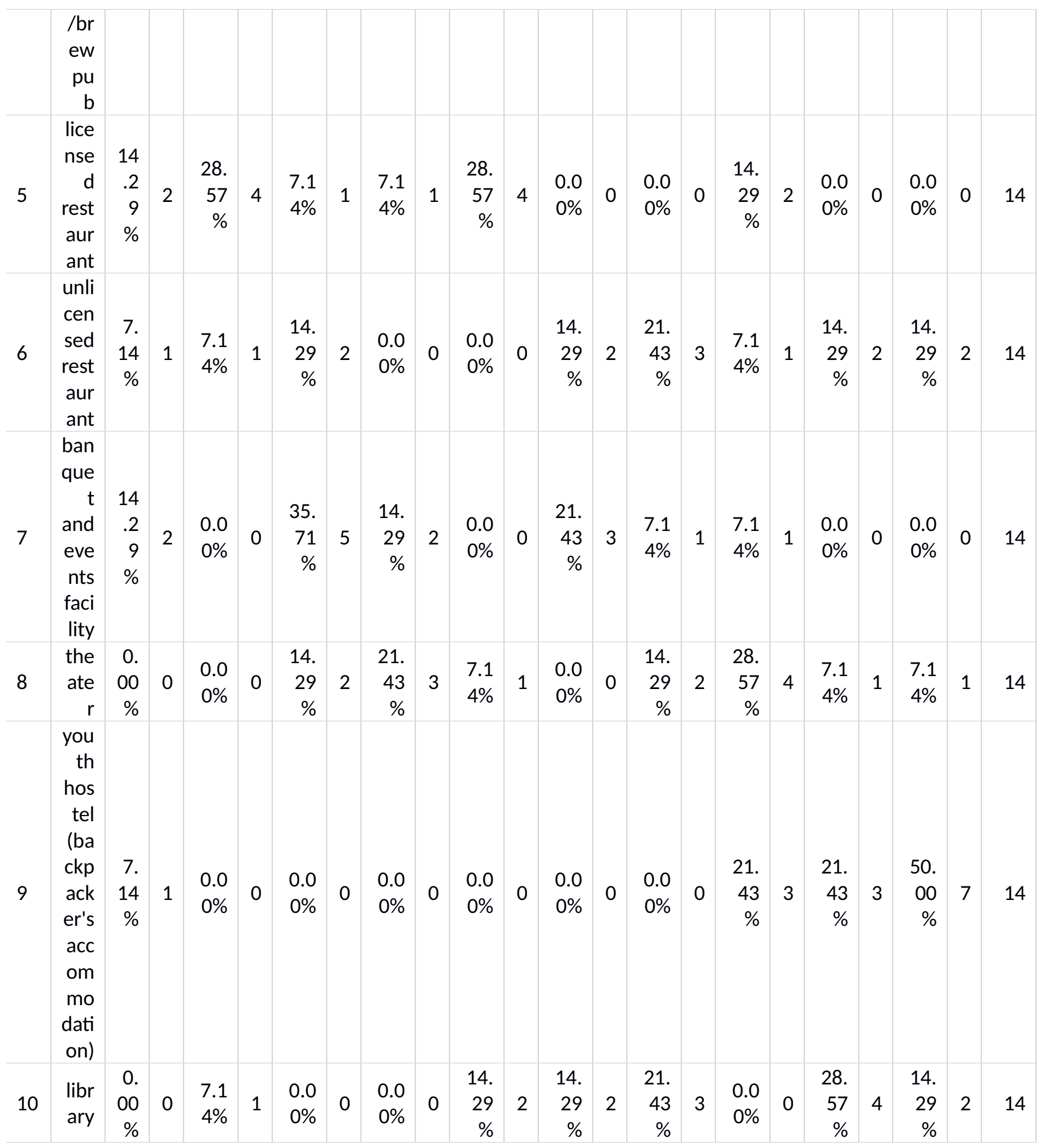




\section{Q9 - Do you have any concerns regarding the future development of this property? If so, please list them below.}

\section{local (within $40 \mathrm{~km}$ of Smiths Falls)}

Do you have any concerns regarding the future development of this property?...

It will only be a leased property so it has limitations to a developer

Access to parking will always be an issue but the surroundings offer lots of potential.

it should be developed to be a destination for boaters and other visitors to the town.

would require a massive investment in bringing the building up to code. Parking would also need an upgrade

I'm concerned about infrastructure surrounding the complex including the old water treatment plant, the confederation bridge that was just removed and the crumbling walls along the river between the Rideau Canal and the complex.

Ensure the preservation and presentation of the buildings' heritage value/character

I am just wishing for a place for youth to be off the street, and not able to get drugs or alcohol, maybe a place where they can get a meal, and sleep for one night.

surrounding area (41-100 km from Smiths Falls, including Kingston and the National Capital Region)

Do you have any concerns regarding the future development of this property?...

I am concerned that plans for development might rely on over-optimistic estimates of the building's structural integrity and livability. An unrealistic assessment of the building's viability could result in stalled projects that would result in losses to developers but more significantly could impact perceptions amongst developers regarding future projects in Smith's Falls.

\section{visitors (101+ km from Smiths Falls}

Do you have any concerns regarding the future development of this property?... 


\section{ApPENDix H}

\section{Precedent Analysis: NaAs Fabriker}

The Nääs mills are located in the small community of Lerum (population 16,000) about $30 \mathrm{~km}$ outside of Gotheberg Sweden. The mills were converted into a business centre in the 1980s to improve employment opportunities in the region and encourage development of small business and one-person enterprises.

In addition to having 60 companies rent the office space for over 30 years, the economic viability of Nääs Fabriker is evidenced by continuous development, growth and evolution of the complex to include a hotel, conference rooms, and restaurants. The economic success of this project is attributed to the strong focus on social and cultural sustainability, specifically, the inspirational industrial heritage setting, a diversity of programs, training programs, the co-working environment, and cultivating a culture of collaboration and exchange of ideas. $^{12}$

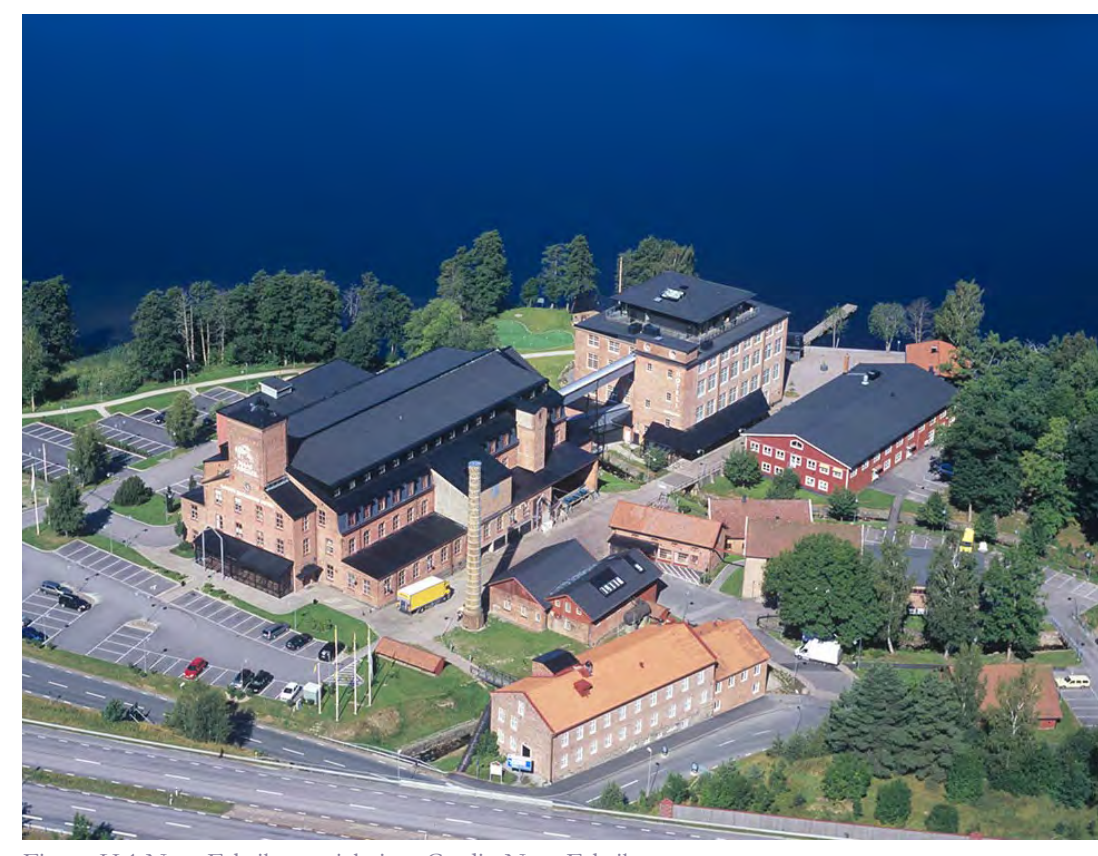

Figure H.1 Naas Fabriker aerial view. Credit: Naas Fabriker

1 Trad Wrigglesworth, "A Novel Approach to Revitalization - the Story of Nääs Business Centre,” in When People Matter, ed. Anders Törnqvist and Peter Ullmark (Sweden : Solna, Sweden: Swedish Council for Building Research ; Distribution, Svensk Byggtjänst, 1989), 178-83.

2 Nääs Fabriker, "Nääs Fabriker,” Nääs Fabriker, accessed October 10, 2016. 
Precedent Analysis: Fogo Island Arts

The Shorefast Foundation is a registered charity and social enterprise committed to building cultural and economic resiliency in rural communities, specifically Fogo Island, Newfoundland in the wake of the cod-fishery collapse. Principles guiding the Shorefast model of social entrepreneurship include: that sustainability depends on nurturing the specificity of place (intellectual heritage, cultural wisdom, local talent, etc.); initial investment can establish viable businesses whose surpluses contribute to the community's resilience and economic wellbeing; that art is a way of knowing, belonging, questioning, innovating, and making sense of the world and as such can contribute to social change.

Fogo Island Arts (an agent of the Shorefast Foundation) supports artistic exploration and production for creative thinkers from around the world through its residency-based contemporary art program. Selected artists exhibit their work at the Fogo Island Gallery, located within the luxurious Fogo Island Inn as part of the new geotourism industry. Furthermore, international conferences, called the Fogo Island Dialogues, bring together key thinkers, artists, academics, economists, geographers, planners and architects to explore how art can influence social change. In addition to providing jobs and a market for local handicrafts, all surplus revenue is fed back into the community. Newfoundland-born architect Todd Saunders designed the contemporary architecture of Fogo Island Inn and the artists residencies using vernacular materials and referencing local building traditions. ${ }^{12}$

1 Fogo Island Arts, "Fogo Island Arts," Fogo Island Arts, accessed November 29, 2016.

2 Shorefast Foundation, "Shorefast Foundation," Shorefast Foundation, accessed January 4, 2017. 

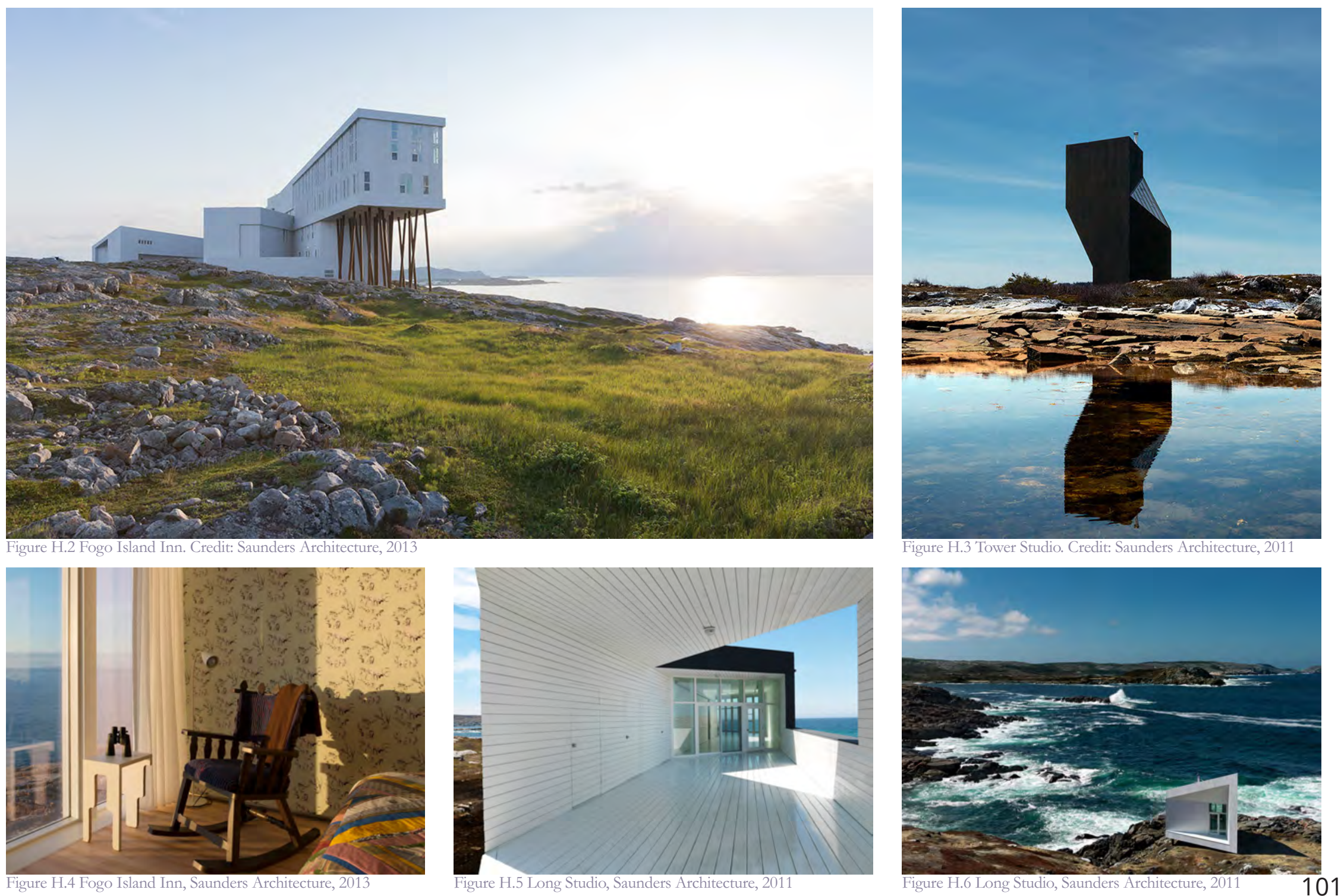
Precedent Analysis: Win This Space \& Main Street

The most visible indicator of economic and social health of a community is the vitality of its downtown commercial district. Main Street ${ }^{\circledR}$ Canada and Win This Space are two successful approaches to reversing the long term effects of depopulation and service decline in smaller communities, an ongoing issue since the end of the Second World War. ${ }^{1}$ Both methods focus on revitalization through economic and cultural activity which has the effect of preserving the heritage character of the historic buildings and streetscapes.

Since 1980, Main Street ${ }^{\circledR}$ Canada has assisted hundreds of Canadian communities by bringing people together to revitalize the economic health and preserve the heritage character of their downtowns. Main Street Coordinator and team (with expertise in design, economic

National Trust for Canada, "Main Street ${ }^{\circledR,}, 2015$

2 Ibid.

3 Jan Hawley, "Win This Space" (Smiths Falls, December 1, 2016). and organizational development and marketing) identify heritage assets and create a strategy for incremental change toward a common vision. ${ }^{2}$

Win This Space is an entrepreneurial competition which began in 2013 in Uxbridge, Ontario and has since spread to the Municipality of Huron East and Peterborough. Contestants participate in business training workshops and submit business proposals with the grand prize package including free rent for a year in the downtown core, mentoring, and other services. The competition in Seaforth, ON (population 2,500) resulted in: the majority of the runners-up opening businesses; $64 \%$ of vacant downtown storefronts filled; 12 new business startups; and new residential developments. ${ }^{3}$ 

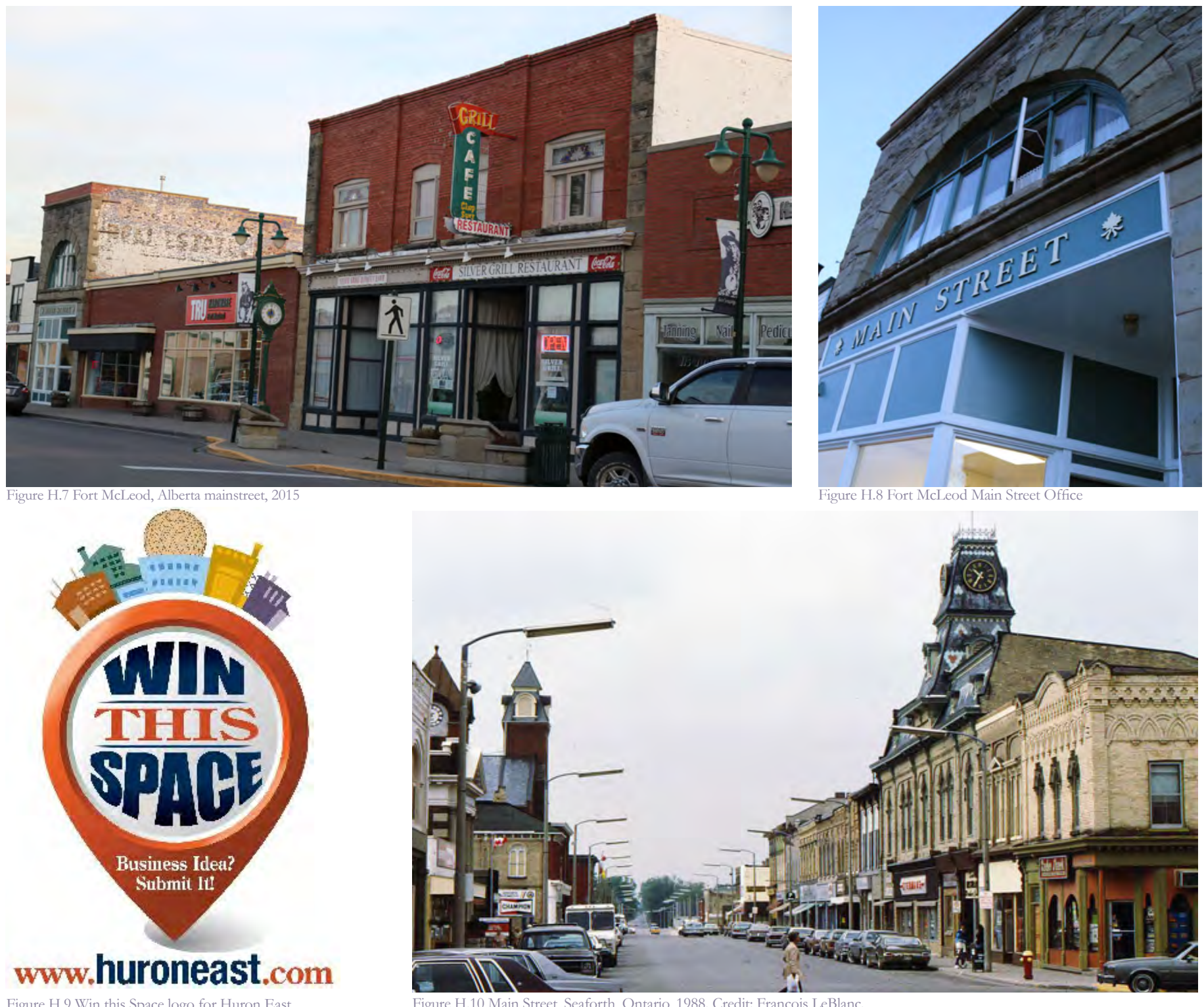
Precedent Analysis: Artscape

Artscape is a Toronto-based non-profit urban development organization specializing in "creative place-making" and transforming communities. Artscape's 11 facilities include community cultural hubs, multi-purpose creative spaces and artist live/work spaces for 149 organizations and over 2,600 people. ${ }^{1}$ The diversity of uses and people is an important factor in the success of the projects. ${ }^{2}$

The multidisciplinary, multi-stakeholder approach unites artists, designers, planners, community activists, environmentalists, government officials and developers to ensure cultural, economic, social and environmental sustainability. Artscape's social enterprise model uses a one-time capital investment to start a project which is sustained through

\footnotetext{
Artscape, "About Artscape," 2011.

2 Berens, 2010.

3 Artscape, 2011

4 Artscape, "Artscape Launchpad," 2017.
}

below-market rent, memberships and user fees - without ongoing operating subsidies. Many Artscape project reuse historic buildings including a school, police station, distillery, and train barns. ${ }^{3}$

Artscape Wychwood Barns cultural hub is the first Canadian heritage building to be certified LEED Gold in 2008. Artscape Launchpad cultural entrepreneurship facility is part incubator, part co-working facility and part entrepreneurship centre full of equipment, technology, programs and services to support business development. Additionally, Artscape DIY, Toolbox and webinars promote knowledge sharing for individuals and groups. ${ }^{4}$ 

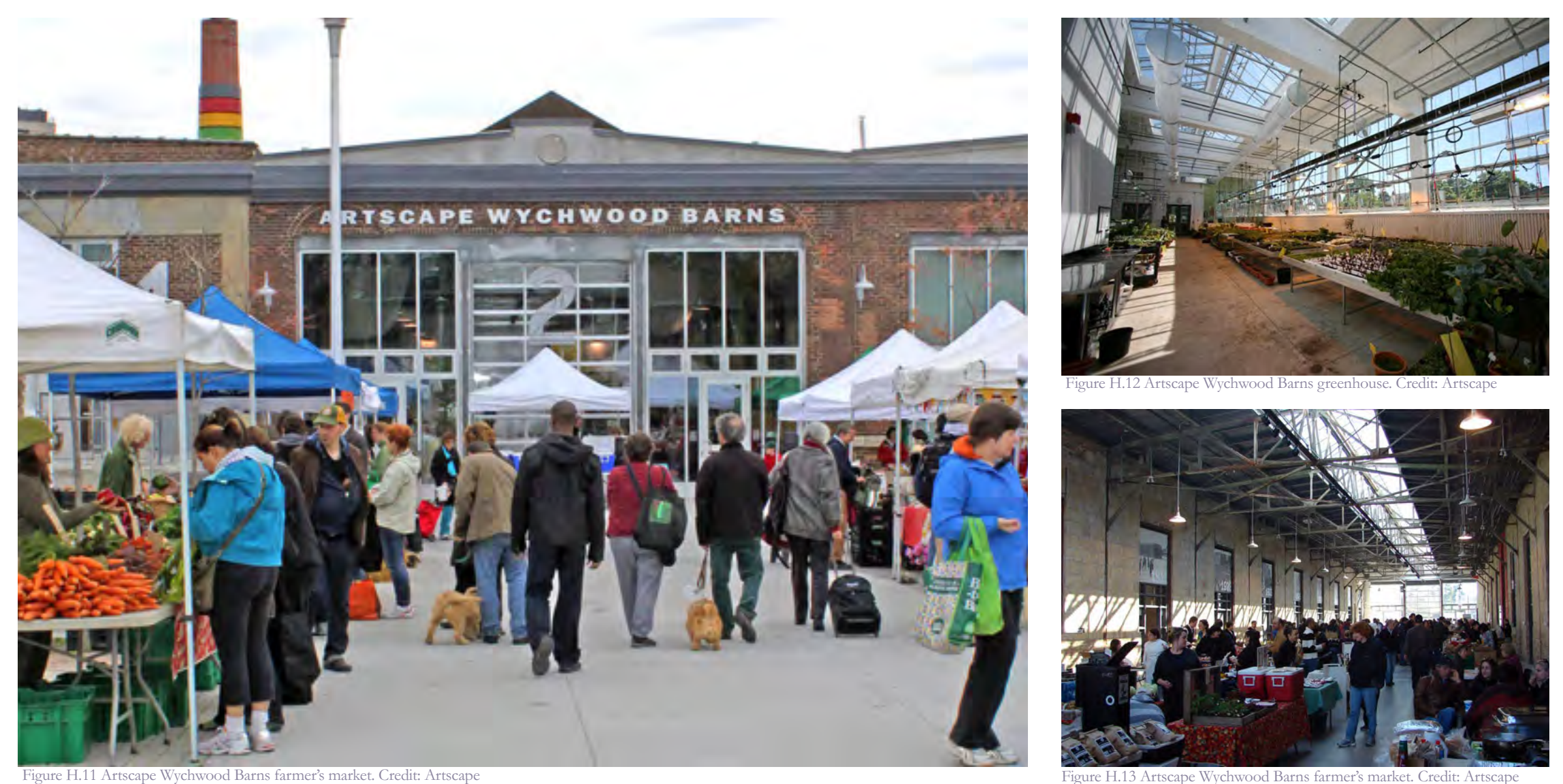